\title{
Annual and seasonal dynamics of deep-sea megafaunal epibenthic communities in Barkley Canyon (British Columbia, Canada): a response to climatology, surface productivity and benthic boundary layer variation
}

\author{
Chauvet Pauline ${ }^{1,}{ }^{*}$, Metaxas Anna ${ }^{2}$, Hay Alex E. ${ }^{2}$, Matabos Marjolaine ${ }^{1}$ \\ ${ }^{1}$ Ifremer Centre de Bretagne, REM/EEP, Laboratoire Environnement Profond, 29280 Plouzané, France \\ ${ }^{2}$ Department of Oceanography, Dalhousie University, Halifax, NS B3H 4R2, Canada \\ * Corresponding author : Pauline Chauvet, email address : pauline.chauvet@ifremer.fr
}

\begin{abstract}
:
Understanding the impact of the environment on temporal trends in the composition and abundance of deep-sea species is essential for forecasting evolution of the community in the context of climate change. The recent development of deep-sea observatories enables multidisciplinary studies of long duration and high temporal resolution. We used a platform at the Ocean Networks Canada NEPTUNE Observatory located in the axis of Barkley Canyon between June 2012 and January 2015 to: (1) characterize the megabenthic community and the environmental conditions in the canyon; (2) investigate temporal patterns in the faunal community; and (3) determine the influence of environmental conditions on the observed patterns. The megafaunal epibenthic community, which included commercially important species, was composed of species known to be able to adapt to low oxygen conditions. A strong seasonal pattern characterized wind speed and direction, wave height, temperature, and chlorophyll concentration at the sea surface. The megafaunal epibenthic community exhibited seasonal patterns which were influenced by in-situ benthic boundary layer currents and temperature, weather conditions and chlorophyll concentration at the sea surface. At inter-annual scales, the surface temperature anomaly event observed in 2013 in the region could potentially impact the community structure with significant changes in species' densities, highlighting the need for longterm monitoring in the region.
\end{abstract}

\section{Highlights}

- The benthic environment in the axis of Barkley Canyon $(-985 \mathrm{~m})$ is stable on time scales $>1 \mathrm{~d}$ and $<3$ $y$, and persistently hypoxic. The epibenthic megafaunal community is composed of species known to be adapted to low oxygen levels. Two major species of the community, C. tanneri and A. fimbria, are of fishery interest. Seasonal variations in the epibenthic megafaunal community on the axis of Barkley Canyon have been revealed. Inter-annual trends in abundance of major species of the community is linked with the surface temperature anomaly "the blob". 
Keywords: Deep-sea observatory, inter-annual variation, seasonal variation, deep-sea canyon, zoobenthos, oxygen minimum zone Canada, British Columbia, Barkley Canyon 


\section{INTRODUCTION}

Submarine canyons are elongated, narrow, steep-sided depressions that generally deepen downslope (IHO, 2013). They incise the continental shelf and slope along all continental margins covering a total area of $4,393,640 \mathrm{~km}^{2}$, which represents $1.21 \%$ of the ocean floor and $11.2 \%$ of continental slopes (Harris et al., 2014). The importance of canyons as providers of ecosystem services was recently reviewed by Fernandez-Arcaya et al. (2017). The complexity of the topography and the heterogeneity of the substrate, in addition to food input, promote a higher abundance, biomass and diversity of organisms in most canyons compared to the adjacent slope (De Leo et al., 2014, 2012; Paine et al., 2014; Puig et al., 2015). Canyons can also provide shelter (Farrugio, 2012), and areas for recruitment (Fernandez-Arcaya et al., 2017, 2013; Puig et al., 2001) and feeding (Ross et al., 2015) for some fish and crustaceans. Unfortunately, these services are threatened by human activities, such as fishing, oil and gas exploitation, and pollution (Fernandez-Arcaya et al., 2017; Martín et al., 2014; Paine et al., 2014; Ramirez-Llodra et al., 2011; Van den Beld et al., 2016). Climate change, by increasing the number and intensity of extreme events, is also predicted to affect canyon communities (Cheung et al., 2010; Danovaro et al., 2001; Ruhl and Smith, 2004). A better understanding of the diversity and dynamics of canyons is thus critical for predicting anthropogenic impact on the ecosystem structure and dynamics.

While most studies in canyons have investigated the role of hydrodynamics, habitat complexity and food availability on the spatial distribution and structure of benthic communities (Duineveld et al., 2001; Gage et al., 1995; Vetter and Dayton, 1999), only a few have focused on temporal dynamics (Aller and Stupakoff, 1996; Blanchard et al., 2010; Ruhl, 2004). However, intra-annual variation related to seasonality or tidal cycles can influence the response of benthic communities (Ruhl, 2004; Tyler, 1988). Canyons can intensify the seasonal upwelling of cold, nutrient rich waters to the surface (Allen et al., 2001; Hickey, 1997), and thus, increase primary production during spring and summer (Granata et al., 2004; Harris and Whiteway, 2011; Macdonald et al., 1987; Ryan et al., 2005). Through both advection and mixing processes, canyons also enhance the exchange of this nutritive material 
between the shelf edge and the deep ocean (Allen and Durrieu de Madron, 2009), and thus seasonally increase the quantity and quality of nutrient supply in canyons (Gooday, 2002; Vetter and Dayton, 1999; Vetter, 1994). In addition, canyons can act as conduits for particle flux, funneling sediment, nutrient and organic matter (OM) from the continental shelf to the abyssal plain (Nittrouer and Wright, 1994; Puig et al., 2014). On the shorter time scales (hours to days) of tidal regimes, internal waves and currents can affect the benthos on the continental margin by modulating daily species activity. For example, patterns such as the nocturnal behavior of the Norway lobster Nephrops norvegicus (Aguzzi, 2011; Sbragaglia et al., 2015) or diel displacements of the sablefish Anoplopoma fimbria within the canyon axis (Doya et al., 2014) have been observed. More stochastic processes such as benthic storms, river discharge, arrival of big carcasses or even trawling events can also affect deep-sea communities (Almeida et al., 2017; Goffredi et al., 2004; Okey, 1997).

Temporal changes in species distribution also can occur as a consequence of transitions through life history stages. For example, spawning females of the monkfish Lophius piscatorius and the hake Merluccius merluccius preferentially inhabit canyons compared to the adjacent slope (Farrugio, 2012). Red crabs Chaceon spp. show patterns of migration linked to reproduction that, in turn, affect the size structure of the population with aggregating behavior in areas near canyons (López Abellán et al., 2002).

High resolution temporal studies over several years can provide insight into intra- and interannual variation in physical and biological processes affecting ecosystem dynamics. The influence of environmental variability and life histories on community dynamics in canyons is not well known. Short-term studies have suggested a potential impact of the environment on some species on time scales from days to seasons, but those studies covered only few months and were not repeated over multiple years (Juniper et al., 2013; Matabos et al., 2014). Understanding natural variability in canyons is paramount for the prediction of the response of benthic communities to short and long- 
term change in environmental conditions, and for the assessment of resilience of species and ecosystems.

A large number of canyons incise the continental margin along the west coast of North America (Harris et al., 2014), yet, in terms of fauna, only few - e.g. Monterey canyon, California (Lundsten et al., 2010; McClain and Barry, 2010; Ryan et al., 2005) - have been investigated. Since 2009, the Ocean Networks Canada (ONC) observatory has provided continuous interdisciplinary data at various locations off Vancouver Island (British Columbia, Canada), encompassing coastal areas to the abyssal plain. One of ONC's research themes focuses on the study of bentho-pelagic coupling in Barkley Canyon, a mid-slope submarine canyon for which little ecological data had previously been available (De Leo et al., 2017; Domke et al., 2017). Two major currents drive regional hydrodynamics: the California current which flows towards the equator in summer and the Alaska current flowing in the reverse direction in winter (Freeland et al., 1984). During summer, the upwelling-favorable wind stress, combined with the canyon's topography, directly affects the water column from a depth of $260 \mathrm{~m}$ to the sea surface (Connolly and Hickey, 2014). The canyon is considered hypoxic ( $<1.40 \mathrm{ml} / \mathrm{L}$ ) (Grantham et al., 2004), and the entire area is located in the Northeast Pacific Oxygen Minimum Zone (OMZ defined as concentration of Dissolved Oxygen-DO <0.5mL/L) (Levin, 2003). Areas within the canyon at similar depths as the ONC platform is mostly inhabited by sea urchins, deep-sea holothurians, pandalid shrimps, gastropods and actiniarians (Domke et al., 2017). Improved knowledge of the benthic communities living in the axis of Barkley canyon and their response to natural variability can help predict how these communities could adapt to changes in regional ocean circulation and the reduction in oxygen recorded in the region (Bograd et al., 2008; Chan et al., 2008). In the hypoxic environment of this submarine canyon, we hypothesized that (i) the epibenthic megafaunal community would be mainly composed of decapods, gastropods and ophiurids, characteristic of hypoxic zones, as well as of species with adaptations to low oxygen conditions (Domke et al., 2017; Levin, 2003); and (ii) the community might respond to a seasonal signal related to winter/summer variations in nutrient input and changes in hydrographic conditions. Using the 
ONC platform, and over a period of three years, we: (i) described the community inhabiting the canyon, (ii) characterized the scales of variation in bottom and surface environmental conditions and chlorophyll concentration, and (iii) determined whether environmental forcing drives community dynamics. 


\section{MATERIALS AND METHODS}

\section{Sampling site}

Barkley Canyon is $\sim 42 \mathrm{~km}$ long, has a maximum width of $8 \mathrm{~km}$ at its head, and incises the continental margin $80 \mathrm{~km}$ west of off Vancouver Island (British Columbia, Canada) from its shallower rim at $\sim 400$ $m$ to the fan at $\sim 2,200 \mathrm{~m}$ depth (Figure 1 ).
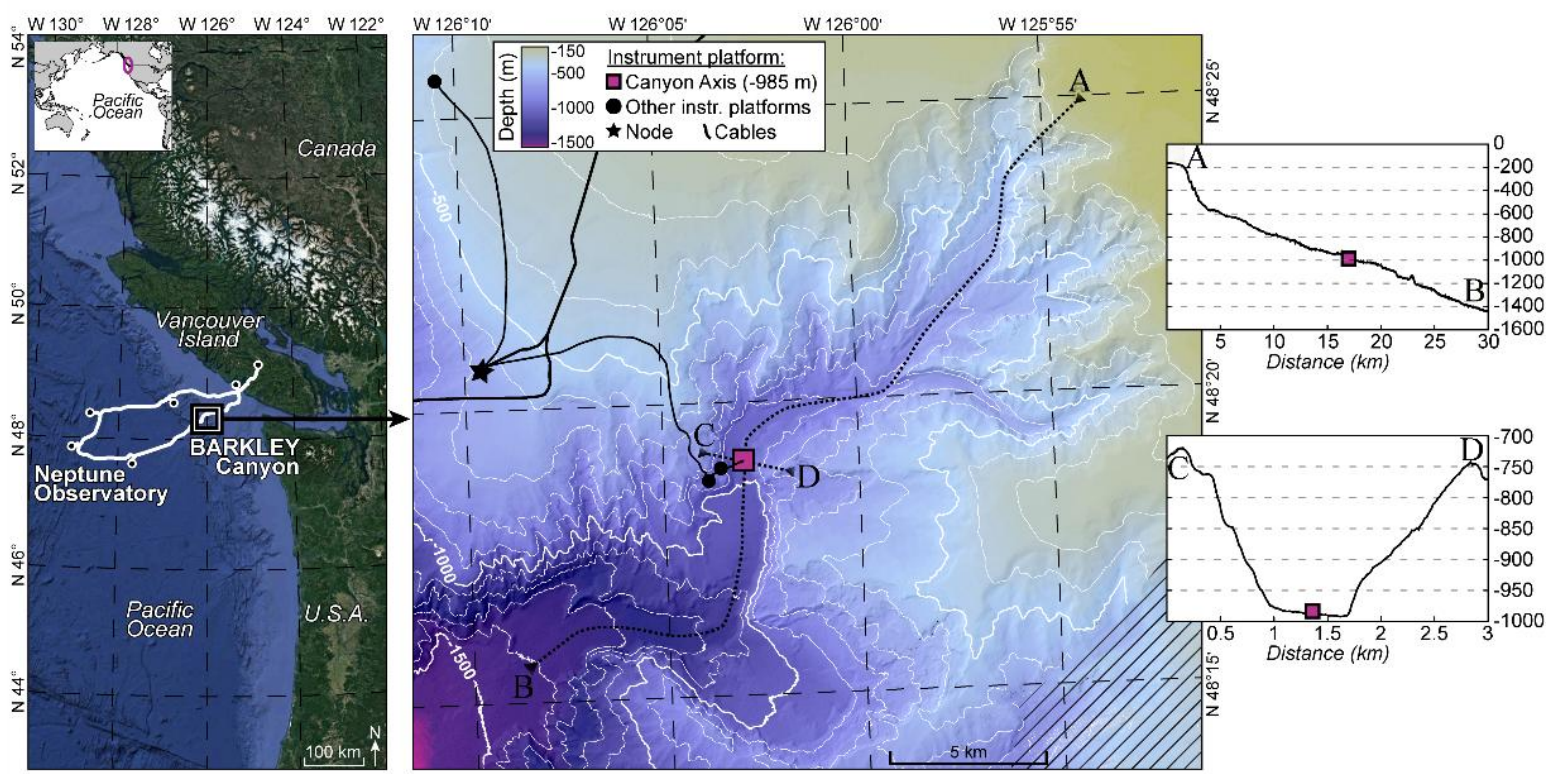

Figure 1: Location map. Left panel: position of the observatory network Ocean Networks Canada offshore Vancouver Island (BC, Canada). Right panel: bathymetric map of Barkley Canyon showing ONC platforms; the axis (POD1 platform) sampling site, at $985 \mathrm{~m}$ depth, is shown as the pink square. Inset side: topography of transects crossing the canyon in length (A-B) and width (C-D).

The sampling site was located at the canyon axis (latitude: $48^{\circ} 19.0087^{\prime} \mathrm{N}$, longitude: $126^{\circ} 03.077^{\prime} \mathrm{W}$, depth: $985 \mathrm{~m}$ ) at the ONC-designated POD1 site. POD1 is a cabled platform equipped with biological and physico-chemical sensors. For more details on cabled network specification, see Juniper et al., (2013).

\section{Data collection}

\section{Environmental characterization}

The data analyzed in this study were collected from 17 June 2012 to 6 January 2015. The instruments attached to POD1, listed in Table 1 , measured: temperature $\left({ }^{\circ} \mathrm{C}\right)$, salinity (psu) and pressure (dbar) at 
a sampling rate of $1 / \mathrm{min}$; oxygen concentration $(\mathrm{mL} / \mathrm{L})$ at $1 / \mathrm{min}$; and Benthic Boundary Layer currents (BBLC) using a 2-MHz Nortek Acoustic Doppler Current Profiler (ADCP) with temporal and spatial resolutions of $10 \mathrm{sec}$ and $1.43 \mathrm{~cm}$, respectively. Atmospheric pressure (dbar), wave height (m) and period $(\mathrm{s})$, and wind speed $(\mathrm{m} / \mathrm{s})$ and direction were acquired by NBDC meteorological buoy 46206 on La Perouse Bank (Tofino, British Columbia, latitude: 4850'24"N, longitude: $126^{\circ} 00^{\prime} 00^{\prime \prime}$, http://www.ndbc.noaa.gov) (Table 1). Surface concentration of chlorophyll was provided as 8-day averages by MODIS, NASA Earth Observations (NEO) Goddard Ocean Color Group (http://neo.sci.gsfc.nasa.gov) (Table 1).

Table 1: List of instruments measuring hydrographic parameters at POD1 station $\left(48^{\circ} 19^{\prime} \mathrm{N}, 126^{\circ} 03^{\prime} \mathrm{W}, 985 \mathrm{~m}\right.$ depth) from 17 June 2012 to 6 January 2015 at the axis of Barkley Canyon (British Columbia, Canada) and collecting atmospheric information at La Perouse buoy $\left(48^{\circ} 50^{\prime} \mathrm{N}, 126^{\circ} 00^{\prime} \mathrm{W}\right.$, Tofino, British Columbia, Canada). We also used 8 day averaged data provided by the MODIS model which uses NASA satellites to obtain surface chlorophyll in a square surface around Barkley Canyon $\left(45^{\circ} 56^{\prime}\right.$ to $50^{\circ} 05^{\prime} \mathrm{N}, 124^{\circ} 87^{\prime}$ to $\left.132^{\circ} 07^{\prime} \mathrm{W}\right)$. BBLc = Benthic Boundary Layer current

\begin{tabular}{|c|c|c|c|c|}
\hline $\begin{array}{l}\text { Sampling } \\
\text { Site }\end{array}$ & $\begin{array}{l}\text { Instruments } \\
\text { Sampling dates }\end{array}$ & Measured parameters & $\begin{array}{l}\text { Sampling } \\
\text { frequency }\end{array}$ & Units \\
\hline \multirow{9}{*}{$\begin{array}{l}\text { Sea-floor } \\
\text { Data }\end{array}$} & \multirow{3}{*}{$\begin{array}{c}\text { ADCP } \\
\text { June-12 to Jan-15 }\end{array}$} & Northward BBLc (Ubar) & $10 \mathrm{sec}$ & $\mathrm{m} / \mathrm{s}$ \\
\hline & & Eastward BBLc (Vbar) & $10 \mathrm{sec}$ & $\mathrm{m} / \mathrm{s}$ \\
\hline & & Temperature & $10 \mathrm{sec}$ & ${ }^{\circ} \mathrm{C}$ \\
\hline & \multirow{5}{*}{$\begin{array}{l}\text { CTD } \\
\text { L3 to Jan-15 }\end{array}$} & Pressure & $1 \mathrm{~min}$ & dbar \\
\hline & & Salinity & $1 \mathrm{~min}$ & psu \\
\hline & & Conductivity & $1 \mathrm{~min}$ & $\mathrm{~S} / \mathrm{m}$ \\
\hline & & Density & $1 \mathrm{~min}$ & $\mathrm{~kg} / \mathrm{m} 3$ \\
\hline & & Temperature & $1 \mathrm{~min}$ & ${ }^{\circ} \mathrm{C}$ \\
\hline & $\begin{array}{c}\text { Oxygen optod } \\
\text { Sept-13 to Jan-15 }\end{array}$ & Oxygen & $1 \mathrm{~min}$ & $\mathrm{~mL} / \mathrm{L}$ \\
\hline \multirow{6}{*}{$\begin{array}{l}\text { Weather } \\
\text { data }\end{array}$} & \multirow{6}{*}{$\begin{array}{l}\text { La Perouse Bank buoy } \\
\text { June-12 to Jan-15 }\end{array}$} & Significant wave height & 1 hour & $\mathrm{m}$ \\
\hline & & Max. zero crossing wave height & 1 hour & $\mathrm{m}$ \\
\hline & & Wave spectrum peak period & 1 hour & s \\
\hline & & $\begin{array}{l}\text { Direction from which the wind is } \\
\text { blowing }\end{array}$ & 1 hour & ${ }^{\circ}$ TRUE \\
\hline & & Horizontal wind speed & 1 hour & $\mathrm{m} / \mathrm{s}$ \\
\hline & & Atmospheric pressure & 1 hour & mbar \\
\hline $\begin{array}{l}\text { Sea-surface } \\
\text { Data }\end{array}$ & $\begin{array}{l}\text { NASA Satellites } \\
\text { June-12 to Jan-15 }\end{array}$ & Surface chlorophyll concentration & 8 days & $\mathrm{mg} / \mathrm{m} 3$ \\
\hline
\end{tabular}




\section{Faunal characterization}

Five-minute video sequences were recorded every two hours with a color camera mounted on a motorized pan/tilt head allowing for a $360^{\circ}$ sweep (all videos are available at http://dmas.uvic.ca/SeaTube). Illumination was available on demand from two Deep-Sea Power and Light variable intensity projectors. Because the pan and tilt limit settings for the camera were modified during annual maintenance cruises, the surface area covered by the camera varied between $3.9 \mathrm{~m}^{2}$ and $9 \mathrm{~m}^{2}$ over the study period (see details in Table 2). For our study, we analyzed the $4^{\text {th }}$ sequence of the day (recorded from 0800 to 0805), every day from 17 June 2012 to 6 January 2015. This time was chosen to minimize the number of gaps in the time-series.

Table 2: Characteristics of cameras installed at each maintenance cruise (1st- June 2012, 2nd-May 2013 and 3rdMay 2014) at POD1 station at $985 \mathrm{~m}$ depth at the axis of Barkley Canyon (British Columbia, Canada). Dates indicate periods in between changes of the camera field of view (for maintenance or technical issues).

\begin{tabular}{|c|c|c|c|c|c|}
\hline Cruises & Dates & Camera & Coordinates & $\begin{array}{c}\text { Sweep } \\
\text { angle }\end{array}$ & $\begin{array}{l}\text { Surface } \\
\text { covered }\end{array}$ \\
\hline 2012 & 17 June 12 to 11 May 13 & $\begin{array}{l}\text { AXIS P1347 } \\
\text { SubAqua } \\
\text { Im.Syst.Inc. }\end{array}$ & $\begin{array}{c}48.31676 \\
-126.05020\end{array}$ & $360^{\circ}$ & $6.1 \mathrm{~m}^{2}$ \\
\hline 2013 & $\begin{array}{l}12 \text { May } 13 \text { to } 15 \text { Feb } 14 \\
16 \text { Feb } 14 \text { to } 05 \text { May } 14\end{array}$ & $\begin{array}{c}\text { Dragonfish } \\
\text { SubC Imaging }\end{array}$ & $\begin{array}{l}48.31658 \\
-126.0502\end{array}$ & $\begin{array}{l}360^{\circ} \\
360^{\circ}\end{array}$ & $\begin{array}{c}9 \mathrm{~m}^{2} \\
7.2 \mathrm{~m}^{2}\end{array}$ \\
\hline 2014 & $\begin{array}{l}11 \text { May } 14 \text { to } 11 \text { Aug } 14 \\
12 \text { Aug } 14 \text { to } 6 \text { Jan } 15\end{array}$ & $\begin{array}{c}\text { Dragonfish } \\
\text { SubC Imaging }\end{array}$ & $\begin{array}{c}48.316644 \\
-126.050166\end{array}$ & $\begin{array}{c}180^{\circ} * 2 \\
100^{\circ}+45^{\circ}\end{array}$ & $\begin{array}{l}6.1 \mathrm{~m}^{2} \\
3.9 \mathrm{~m}^{2}\end{array}$ \\
\hline
\end{tabular}

Each video was viewed using VLC media player ${ }^{\circledast}$. All visible fauna (size $>0.5 \mathrm{~cm}$ ) were counted and identified to the lowest taxonomic rank possible. Because of the challenge to identify individuals at the species level from imagery, we used Operational Taxonomic Units (OTU) when species identification was not possible. We did not collect video information when sediment suspension obscured the seafloor. Density data were obtained by dividing abundance by the surface area of the field of view. 


\section{Data analysis}

\section{Environmental characterization}

Because the temporal range of the ADCP data acquisition matched the biological sampling period, we used temperature data from the ADCP rather than the CTD (Table 1). Temperature, oxygen, salinity and density were averaged daily. The 10-second ADCP velocity data were first averaged in 10-minute intervals, and the resulting values averaged over the full vertical extent of the profile $-\sim 0.2$ to 1.75 $\mathrm{m}$ height above bottom - to yield a single time series for each Cartesian component of near-bed velocity. Daily-averaged velocities were then computed from these data and used as up-canyon and cross-canyon Benthic Boundary Layer currents (BBLC). Surface chlorophyll concentrations as provided by NASA Earth Observation (https://neo.sci.gsfc.nasa.gov) were already pooled across 8 days with a precision of 0.25 degrees. For these data, we defined a surface area of $144 \mathrm{~km}^{2}$ around Barkley Canyon (Appendix 1) over which we averaged the data at weekly intervals. Wind speed and direction were pooled using vector averaging to obtain daily-averaged wind speed and direction information. Atmospheric pressure and wave height were also daily averaged. The daily Anomaly of Sea Surface Temperature (ASST) was calculated as the difference between the daily mean of Sea Surface Temperature (SST) over the entire time span recorded by the buoy (from 1988 to 2015) and the daily mean of the SST of each date of interest (each day from 17 June 2012 to 6 of January 2015).

For data gaps of less than 5 days, missing values were substituted using k-nearest neighbor modelling (package VIM). The Whittaker-Robinson periodogram (Whittaker and Robinson, 1923) method was used to identify the dominant periods in the environmental variables. The underlying statistic measuring the amplitude used in this periodogram function is the standard deviation of the means of the columns of the Buys-Ballot table (Legendre and Legendre, 2012). The WR periodogram can handle missing values in the datasets. Prior to periodogram analyses, datasets were tested for stationarity. For non-stationary cases, trends were removed by linear regression and residuals were used in the periodogram analysis. Some degree of caution is needed during interpretation as this kind of periodogram also finds the harmonics of basic periods to be significant. 


\section{Community dynamics: composition and diversity}

We defined major and rare species based on density (abundance per $\mathrm{m}^{2}$ ) and species recurrence over time. Species representing less than $5 \%$ of the community over the entire period were defined as rare. Conversely, major species represented more than $90 \%$ of the community over the entire period. We used Whittaker-Robinson periodograms to identify significant periodicities in changes of density over time for each major species.

Because not all species respond similarly to changes in environmental conditions, particularly depending on their motility, we aggregated the monthly (sum) density of each OTU by motility category to explore a possible temporal trend. Swimmers aggregated all the species able to move against current in the water mass, mostly fish. Walkers represented the species able to walk on the sediment and either jump or swim for short distance, here the arthropods. The species not able to swim against strong current and often observed through the camera as passively moving in the water mass were considered as planktonic. Crawlers grouped all the species able to crawl on the sediment and unable to either jump or swim for even a short distance, mostly gastropods and echinoderms. Correlations between monthly aggregated densities of all categories were tested using Kendall correlations because data were not normally distributed. We used Whittaker-Robinson periodograms to identify significant periodicities in changes of density over time for each category.

To assess temporal patterns in community composition and explore a potential impact of maintenance cruises on these patterns, a multivariate regression tree (Borcard et al., 2011; De'Ath, 2002) was applied to Hellinger-transformed densities (see method description in Appendix 2 and 3). Because none of the identified splits corresponded to the dates of the maintenance cruises, we disregarded a potential observation bias related to maintenance activities or changes in camera position and analyzed the entire time-series.

For all multivariate analyses, data were Hellinger-transformed to reduce the importance of doublezeros (i.e., to avoid inferring similarity between sites from double absences) in the data matrix 
(Legendre and Gallagher, 2001). This transformation preserves the Hellinger distance, which is appropriate in methods based on the Euclidean distance as those used below.

Species diversity was calculated for each day and month, i.e. monthly density is the sum of the $30 / 31$ daily densities. Alpha biodiversity was computed on non-transformed densities using Shannon's and Simpson's diversity indices.

Principal Component Analysis was conducted to visualize the distribution of weekly community composition on the first two principal axes and define potential groups in community composition for each season. To avoid bias due to zero-inflated data and lighten the data matrix, the rare species were removed from the PCA. The aggregation per week was done by summing all daily densities over one week, and the obtained weekly values were then Hellinger-transformed.

\section{Relationships between community dynamics and the environment}

To identify temporal structure in community composition, and the role of potentially important environmental factors regulating this structure, a distance-based Moran's eigenvector maps (dbMEM) analysis was performed. dbMEM, belonging to spatial eigenfunction analyses, computes eigenvectors of spatial configuration matrices and uses them as predictors in linear models (Griffith and Peres-Neto, 2006). Extension to multivariate time series analysis is straightforward (Legendre and Gauthier, 2014) and dbMEM can be used to control for temporal correlation (Peres-Neto and Legendre, 2010). dbMEM is particularly useful for irregularly spaced temporal data (e.g. gaps in sampling dates because of maintenance cruises) (Borcard and Legendre, 2002). The steps involved in the generation of positive dbMEMs (+dbMEMs) (Rádková et al., 2014) are given in appendix 4. Scalograms were used to group +dbMEMs into 3 sub-models (Broad, Medium and Fine), defined as groups separated by non-significant $+\mathrm{dbMEMs}$ (Legendre and Gauthier, 2014). The first eigenvectors describe broad temporal structures, i.e., those that encompass several months to a year, while the last eigenvectors describe fine temporal structures (i.e. few days). To identify the corresponding time periods in each submodel, we computed a contingency periodogram (Borcard et al., 2004). These 
sub-models were then used as explanatory variables in redundancy analysis to: (1) estimate the percentage of variation in community composition explained by each sub-model; and (2) highlight the relative contribution of each environmental variable to the temporal structure associated with the scale of each sub-model. Partition of the variation in the faunal matrix among the two types of explanatory factors (the environment and the temporal structure), using redundancy analysis ordination (Legendre and Legendre, 1998) was illustrated through a Venn diagram (library vegan) (Legendre and Gauthier, 2014). The environmental variables available for the entire time-series were the cross-slope and along-slope winds, wave height and period, atmospheric pressure, in situ seafloor temperature and the up- and cross-canyon BBLc.

Chlorophyll concentration at the sea surface was tested separately from the other environmental parameters as we only had the weekly averaged values instead of higher daily sampling rates. The response of the four major species to the chlorophyll concentration was tested using Cross Correlation Function (CCF) analysis which gives the correlation between two time series computed as a function of the lag of one with respect to the other (Venables and Ripley, 2002). Because we are interested in the potential influence of chlorophyll concentrations on the density of fauna, only the negative lag will be presented. 


\section{RESULTS}

\section{Environmental characterization}

We used data on atmospheric and in situ factors to characterize the environment at our sampling site (Table 3). The weather in the canyon area was characterized by mean wave heights of $2.03 \mathrm{~m}$ and wind speeds of $\sim 5.58 \mathrm{~m} / \mathrm{s}$ (Table 3). The highest wave heights $(>4 \mathrm{~m}$ ) were recorded in winter (end of November- early December 2012 - February 2013; end of September 2013 - January 2014; December 2014; Figure 2). In summer, the along-shelf wind speeds were stronger than the crossshelf winds, and mostly negative, corresponding to upwelling conditions. The reverse was observed in winter (Figure 2). Periodogram analysis confirmed an annual cycle with significant periods between 276 and 373 days for cross-slope wind, 272 and 382 days for along-slope wind, 271 and 350 days for atmospheric pressure and 262 and 348 days for wave height and period. They also showed significant periods of 289 to 412 days for sea surface temperature and 312 to 385 days for the anomaly of sea surface temperature (Appendix 4, Figure 2).

Table 3: Environmental parameters from 17 June 2012 to 6 January 2015 measured (i) at 985 m depth at the axis of Barkley canyon and (ii) at the sea surface around Barkley Canyon (British Columbia, Canada). Wave height (WH), wind speed (WS), atmospheric pressure (AtmP), sea surface temperature (SST), daily anomaly of sea surface temperature (ASST) parameters are given or derived from hourly data recorded by LaPerouse buoy (Tofino, British Columbia). Chlorophyll (chl) data values are a spatial averaged of a square surface around Barkley Canyon $\left(45^{\circ} 56^{\prime}\right.$ to $50^{\circ} 05^{\prime} \mathrm{N}, 124^{\circ} 87^{\prime}$ to $132^{\circ} 07^{\prime} \mathrm{W}$ ) obtained from the 8 -day averages given by the MODIS model (neo.sci.gsfc.nasa.gov). In situ absolute value of BBLc, transverse component (Ubar) and upcanyon component (Vbar) and temperature (Temp) (from June 2012 to January 2015), and oxygen ([O2]), salinity (Sal) and density (De) (from September 2013 to January 2015) were measured at POD1 ONC observatory site using ADCP for BBLC and temperature, an Oxygen optode and a CTD for the salinity and density.

\begin{tabular}{|c|c|c|c|c|c|c|c|c|c|c|c|c|}
\hline & \multicolumn{6}{|c|}{ Surface data } & \multicolumn{6}{|c|}{ In-situ benthic boundary layer data } \\
\hline & $\begin{array}{c}\mathbf{W H} \\
\mathrm{m}\end{array}$ & $\begin{array}{l}\text { WS } \\
\mathrm{m} / \mathrm{s}\end{array}$ & $\begin{array}{l}\text { AtmP } \\
\text { mbar }\end{array}$ & $\begin{array}{l}\text { SST } \\
{ }^{\circ} \mathrm{C}\end{array}$ & $\begin{array}{c}\text { ASST } \\
{ }^{\circ} \mathrm{C}\end{array}$ & $\begin{array}{c}\mathrm{Chl} \\
\mathrm{mg} / \mathrm{L}\end{array}$ & $\begin{array}{c}{[0]} \\
\mathrm{mL} / \mathrm{L}\end{array}$ & $\begin{array}{l}\text { Sal } \\
\text { psu }\end{array}$ & $\begin{array}{c}\text { De } \\
\mathrm{kg} / \mathrm{m} 3\end{array}$ & $\begin{array}{c}\text { Temp } \\
{ }^{\circ} \mathrm{C}\end{array}$ & $\begin{array}{c}|\mathrm{Vbar}| \\
\mathrm{m} / \mathrm{s}\end{array}$ & $\begin{array}{c}\text { |Ubar | } \\
\mathrm{m} / \mathrm{s}\end{array}$ \\
\hline Min & 0.4 & 0 & 976.7 & 7.2 & -4 & 0.29 & 0.24 & 34.00 & 1031 & 3.51 & 0 & 0 \\
\hline Max & 8.2 & 19.1 & 1045.3 & 16.7 & 3.8 & 7.09 & 0.34 & 34.40 & 1032 & 4.07 & 0.2 & 0.13 \\
\hline Mean & 2.0 & 5.6 & 1017.6 & 11.7 & -0.2 & 1.17 & 0.29 & 34.38 & 1032 & 3.76 & 0.03 & 0.02 \\
\hline Sd & 1.22 & 3.57 & 8.10 & 2.47 & 1.60 & 0.871 & 0.020 & 0.023 & 0.026 & 0.090 & 0.020 & 0.015 \\
\hline
\end{tabular}


The concentration of surface chlorophyll also followed a seasonal pattern with a first peak in April and a second in July every year (Figure 2); periodogram revealed an annual cycle with significant period between 51 and 56 weeks ( 357 to 392 days). A maximum concentration of $7.09 \mathrm{mg} / \mathrm{L}$ (Table 3) occurred in July 2014 (Figure 2). The daily anomaly in sea surface temperature started to increase in June 2014 and stayed higher than previous observations until January 2015.

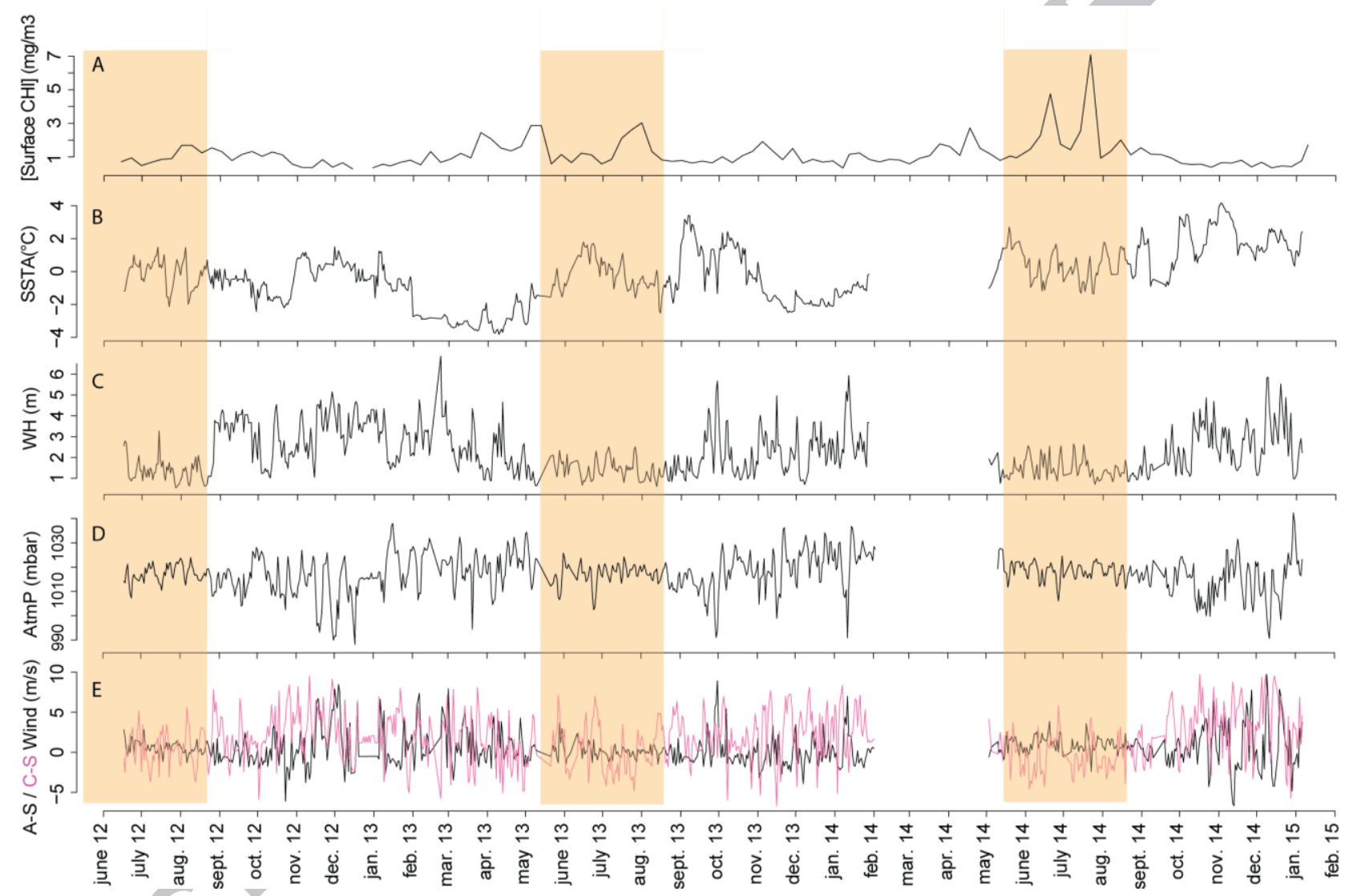

Figure 2: Time series of A- surface chlorophyll concentration (8-day averaged of a single value representing a sampling in a square surface around Barkley Canyon $\left(45^{\circ} 56^{\prime}\right.$ to $50^{\circ} 05^{\prime} \mathrm{N}, 124^{\circ} 87^{\prime}$ to $132^{\circ} 07^{\prime} \mathrm{W}$ ) obtained with the MODIS model using NASA satellites, B-Daily anomaly of sea surface temperature obtained from sea surface temperature recorded from 1988 to 2015 by La Perouse buoy (Tofino, British Columbia, Canada), ) C- wave height (daily averaged) and D- atmospheric pressure (daily averaged) measured by LaPerouse buoy (Tofino, British Columbia, Canada) ,E- along-slope (black line) and cross-slope (red line) wind (daily vectored averaged). Yellow shading highlights summer time. Blue lines represent the 3 years averages. Sampling dates are from 17 June 2012 to 6 January 2015. 
The very low standard deviation of the physico-chemical parameters (temperature, salinity and density) (Table 3) revealed a relative homogeneous BBL environment over the study period (scale of ordinates, Figure 3). Conversely, BBL currents (BBLC) showed high standard deviation, however transverse-canyon and up-canyon mean strength were weak and rarely exceeded means of $0.02 \mathrm{~m} / \mathrm{s}$ and $0.03 \mathrm{~m} / \mathrm{s}$, respectively (Table 3, Figure 3). Over the entire sampling time, the dominant current was oriented down-canyon. The variability in BBL current speed relative to this down-canyon drift was mainly tidal, with amplitudes of 30 to $70 \mathrm{~cm} / \mathrm{s}$ (results not shown). On longer time scales - i.e., weeks to months - the magnitude of the velocity variability was $<5 \mathrm{~cm} / \mathrm{s}$ (Figure 3). Variations on seasonal and semi-annual time scales, based on 5-days averaged values, had amplitudes of order 1 $\mathrm{cm} / \mathrm{s}$ (not shown). Oxygen concentration remained below the threshold for hypoxia ( $\max =0.34 \mathrm{~mL} / \mathrm{L}$ -Grantham et al., 2004) and showed a decrease from April 2014 to November 2014 (Figure 3). Periodograms performed on BBLc showed three types of significant periods of cycles: a fine scale of 4 days, a medium scale from 159 to 175 days, and a broad scale from 292 to 340 days. Even though amplitude of variation was weak, the physico-chemical parameters (salinity, pressure, density, temperature and oxygen) also showed a broad cycle of 290-400 days. 


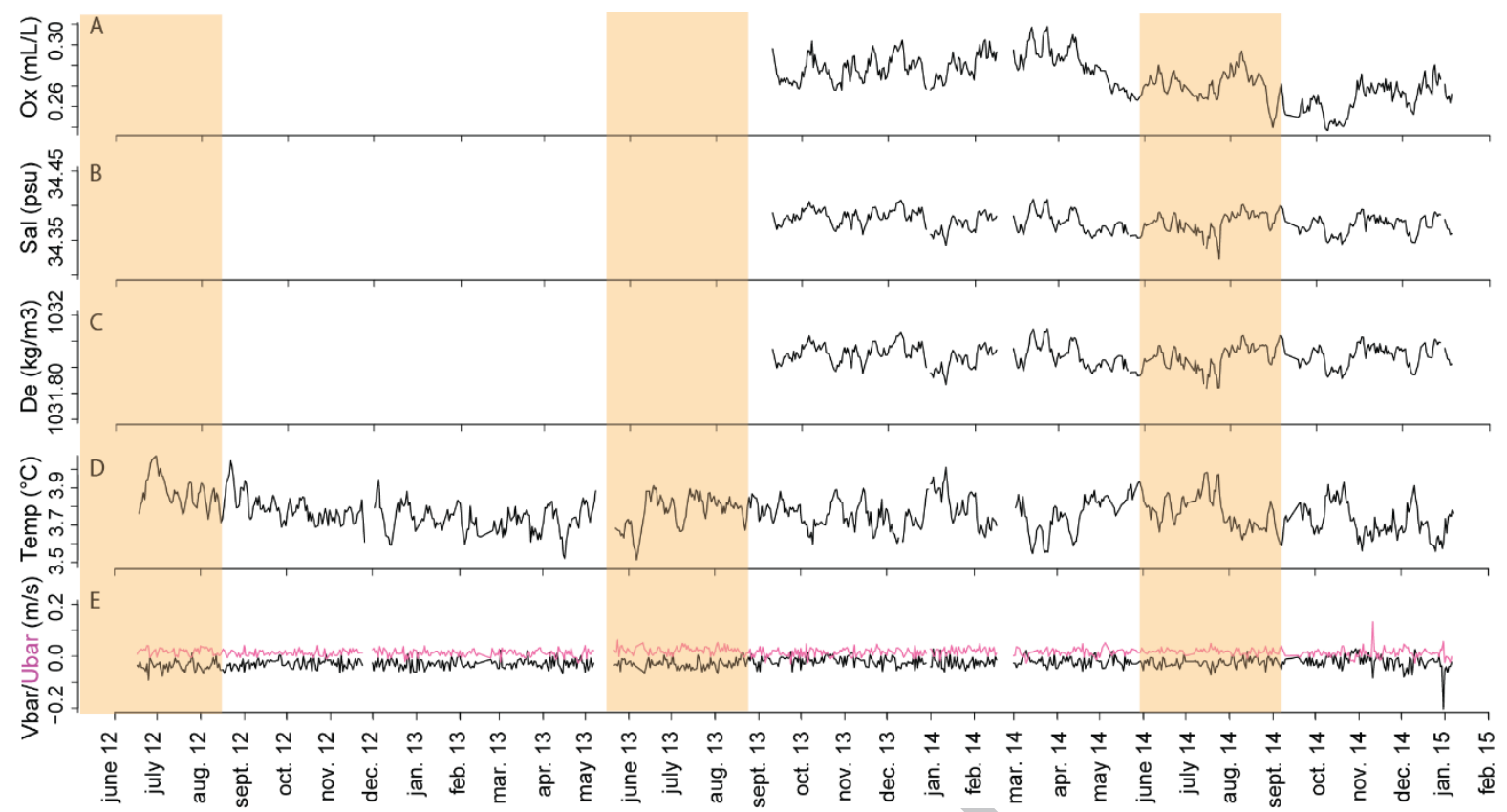

Figure 3: Time series of in-situ measurements made at POD1 ONC observatory site at the axis of Barkley Canyon (British Columbia, Canada) at $985 \mathrm{~m}$ depth using an optode (oxygen), a CTD (salinity and density) and an ADCP (BBLc and temperature). A- Oxygen concentration ( $\mathrm{ml} / \mathrm{L}$ ), B- Salinity (psu) C- Density $\left(\mathrm{kg} / \mathrm{m}^{3}\right)$, DTemperature $\left({ }^{\circ} \mathrm{C}\right)$, E- Up-canyon (black) and transverse- canyon Benthic Boundary Layer currents $(\mathrm{m} / \mathrm{s})$. Yellow shading highlights summer time. Sampling dates are from 17 June 2012 to 6 January 2015.

Community structure composition and diversity

A total of 72,367 individuals were identified over the 847 days of sampling. We found 28 OTUs, including 4 identified to genus, and 7 identified to species (Table 4). Major and rare species constituted $14 \%$ and $46 \%$ of the total community, respectively. 
Table 4: List of benthic megafauna recorded from the axis of Barkley Canyon (British Columbia, Canada) at 985 m depth from 17 June 2012 to 6 January 2015 and identified to the lowest taxonomic rank possible. Species considered as major are highlighted in blue and those considered as rare in grey. Buccinidae_OTU_2 could also be a member of the Ranellidae family. Actiniarians were always observed on Buccinidae_OTU_2 shell and are thus categorized as crawlers.

\begin{tabular}{|c|c|c|c|}
\hline Phylum & OTUs name & Total of observations & Motility \\
\hline \multirow[t]{11}{*}{ Chordata } & Anoplopoma fimbria & 10740 & Swimmer \\
\hline & Sebastolobus sp. & 11 & Swimmer \\
\hline & Coryphaenoides sp. & 125 & Swimmer \\
\hline & Bothrocara molle & 24 & Swimmer \\
\hline & Eelpout_OTU_1 & 781 & Planktonic \\
\hline & Lycodapus sp. & 2 & Swimmer \\
\hline & Lycenchelis sp. & 27 & Swimmer \\
\hline & Eptatretus sp. & 99 & Swimmer \\
\hline & Careproctus melanurus & 1 & Swimmer \\
\hline & Bathyagonus niggripis & 32 & Swimmer \\
\hline & Embassichthys bathybius & 2 & Swimmer \\
\hline \multirow[t]{2}{*}{ Mollusca } & Buccinidae_OTU_1 & 1124 & Crawler \\
\hline & $\begin{array}{l}\text { Buccinidae_OTU_2 } \\
\text { Ranellidae_OTU_1 }\end{array}$ & 3217 & Crawler \\
\hline \multirow[t]{7}{*}{ Arthropoda } & Paguroidea & 98 & Walker \\
\hline & Chionoecetes tanneri & 49298 & Walker \\
\hline & Galatheidae & 283 & Walker \\
\hline & Hippolytidae & 1070 & Walker \\
\hline & Caridae & 782 & Walker \\
\hline & Mysids: ?Eucopia spp. & 4172 & Planktonic \\
\hline & Pandalidae & 2 & Walker \\
\hline \multirow[t]{3}{*}{ Echinodermata } & Asteroidea_OTU_1 & 38 & Crawler \\
\hline & Solasteridae & 2 & Crawler \\
\hline & Ophiuroidea & 2 & Crawler \\
\hline \multirow[t]{3}{*}{ Cnidaria } & Actiniaria & 82 & Crawler* \\
\hline & Scyphozoa & 197 & Planktonic \\
\hline & Poralia rufescens & 130 & Planktonic \\
\hline Ctenophora & Ctenophora & 23 & Planktonic \\
\hline Annelida & Polychaete & 3 & Crawler/Swimmer \\
\hline
\end{tabular}


Major species included the grooved tanner crab Chionoecetes tanneri (more than 49,200 observations), the sablefish Anoplopoma fimbria (> 10,700 observations), a zooplanktonic species, probably mysids of the genus Eucopia ( $>4,100$ obs.), and a species of buccinid or ranellid snails (> 3,200 observations in total) (Table 4 and Figure 4). Periodograms revealed two significant cycles for C. tanneri: (i) between 198 and 220, and (ii) 334 and 338 days; and two for Buccinidae_OTU_2: (i) 111 and 112 days (and its probable harmonic at 223 days), and (ii) 335 days. No significant cycle was observed for A. fimbria. For the Mysids, periodograms revealed finer scale cycles of 7 days (and probable harmonics of 21, 42 and 84 days) (Appendix 4, Figure 5).
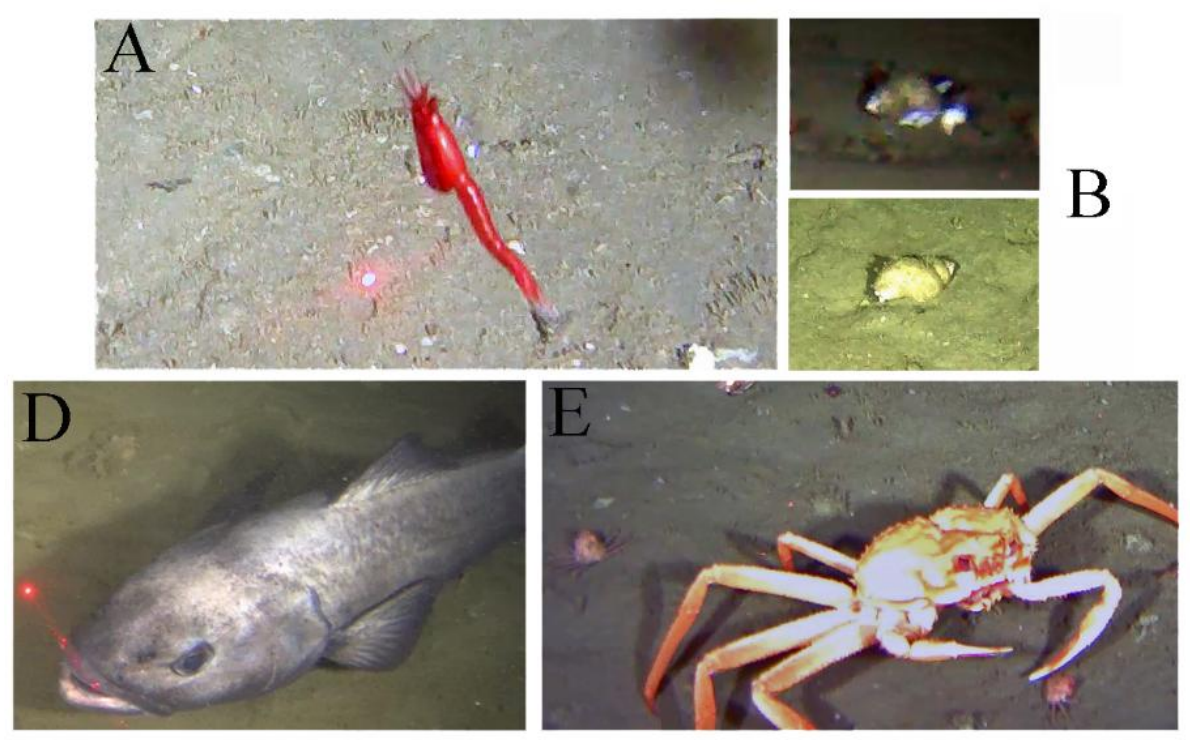

Figure 4: Images of the major species observed with a stationary video camera at the axis of Barkley Canyon (British Columbia, Canada) at 985 m depth from 17 June 2012 to 6 of January 2015. A Mysids, likely Eucopia spp; B Buccinidae_OTU_2; C Buccinidae_OTU_1; D Anoplopoma fimbria and; E Chionoecetes tanneri.

C. tanneri and A. fimbria displayed the highest densities (Figure 5). The density of $C$. tanneri showed different peaks during the sampling period with a regular increase in October each year, and highest densities observed in autumn 2014. Density of mysids was very low $\left(<2 \mathrm{ind} / \mathrm{m}^{2}\right)$ from June 2012 to May 2013, and then steadily increased until the end of the study period. Buccinidae_OTU_2 had the lowest abundance from June to late July of each year, with this low-density period extending into 
winter 2013. A. fimbria showed no clear intra or inter-annual pattern in density, although, as for $C$. tanneri, we observed highest density in autumn 2014 (Figure 5).

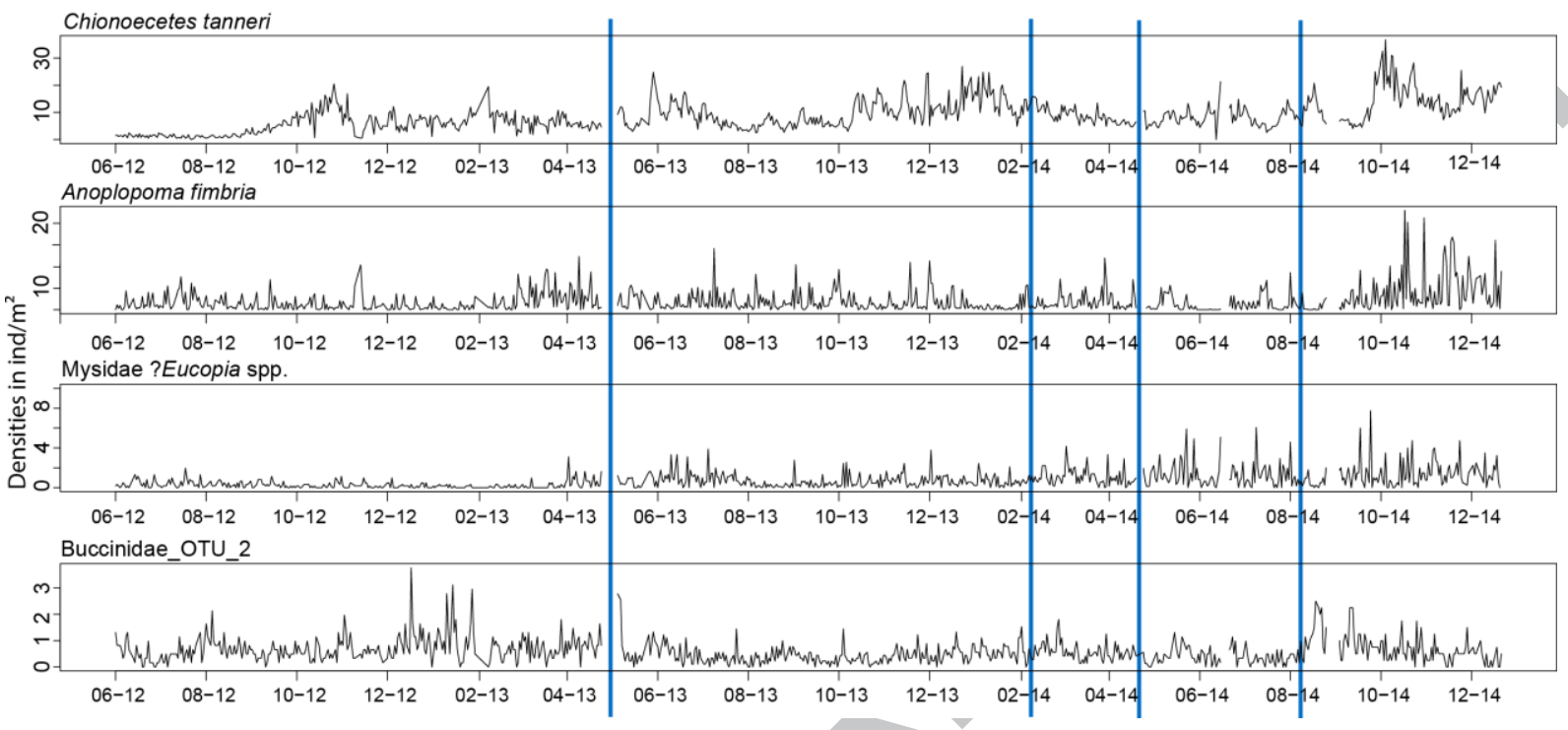

Figure 5: Time series of density (ind $/ \mathrm{m}^{2}$ ) of major species recorded with a stationary video camera at the axis of Barkley Canyon (British Columbia, Canada) at 985 m depth from June 2012 to January 2015. The mysids were probably ?Eucopia spp. Blue vertical lines indicate a change in camera parameters which modified the field of view and/or the area coverage.

When megafauna were grouped by their motility capacity, walkers dominated during the entire sampling period (Figure 6). The monthly aggregated density of the planktonic category was significantly correlated to that of both walkers and swimmers (Table 5).

Table 5: Results of the correlations performed on the densities of all OTUs aggregated by month and motility at $985 \mathrm{~m}$ depth at the axis of Barkley Canyon (British Columbia, Canada) from 17 June 2012 to 11 January 2015. $T$ = Kendall rank correlation coefficient and « ns » = non-significant.

\begin{tabular}{ccccccc} 
& \multicolumn{2}{c}{ Swimmers } & \multicolumn{2}{c}{ Planktonic } & \multicolumn{2}{c}{ Crawlers } \\
\cline { 2 - 7 } & $\mathrm{T}$ & $\mathrm{p}$-value & $\mathrm{T}$ & $\mathrm{p}$-value & $\mathrm{T}$ & $\mathrm{p}$-value \\
Walkers & 0.21 & 0.089 & 0.46 & 0.000 & 0.24 & 0.050 \\
Swimmers & & & 0.31 & 0.012 & & $\mathrm{~ns}$ \\
Planktonic & & & & & & $\mathrm{ns}$ \\
\hline
\end{tabular}


Periodograms performed on the monthly aggregated density of each motility group showed no significant periods for walkers and an annual cycle with significant periods of 12,15 and 11 months for swimmers, crawlers and the planktonic group, respectively (Appendix 4, Figure 4).

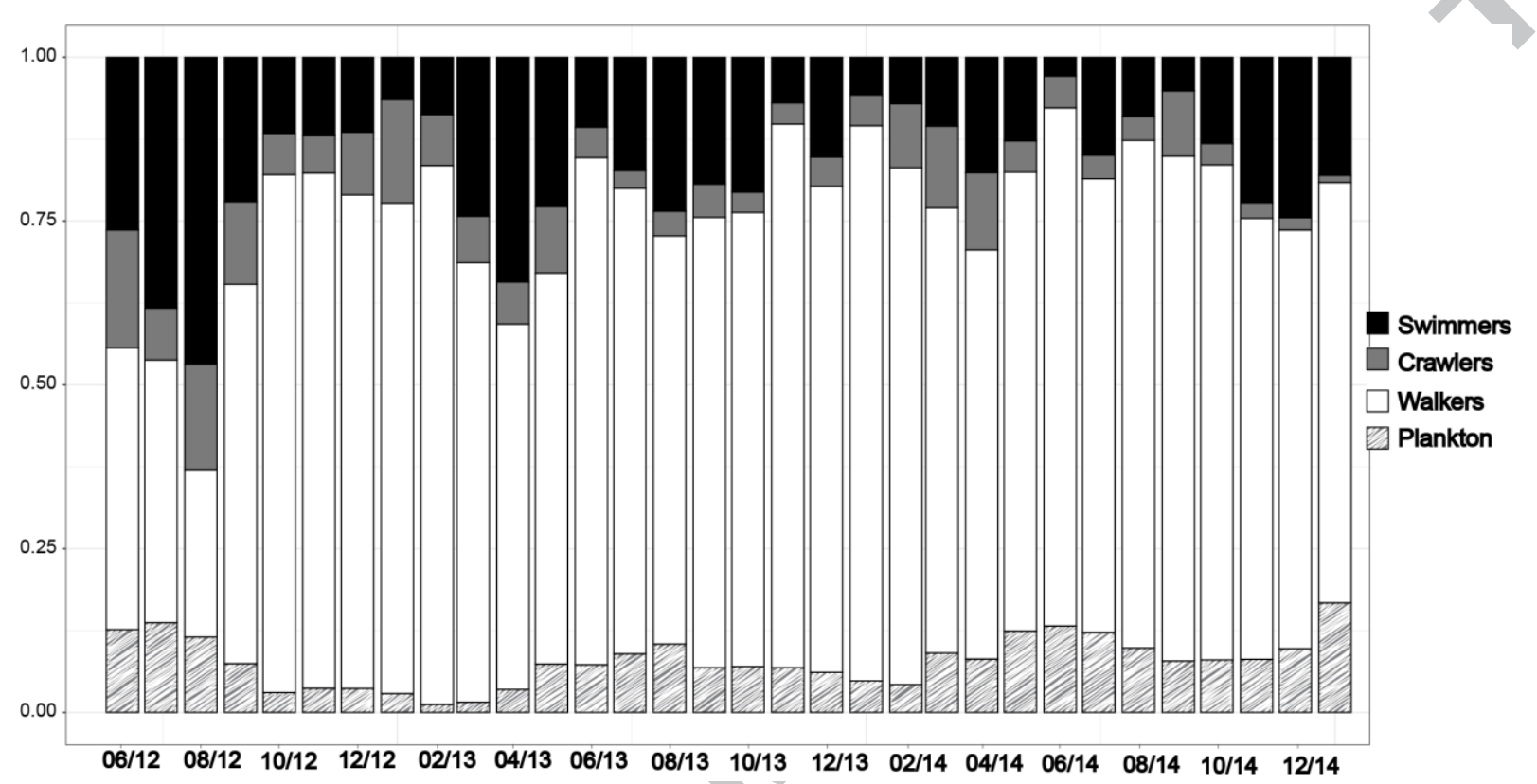

Figure 6: Cumulative frequency of species density aggregated by their motility type and by month, sampled once per day with stationary video camera from $08 \mathrm{~h} 00$ to $08 \mathrm{~h} 05$ at $985 \mathrm{~m}$ depth at the axis of Barkley Canyon from 17 June 2012 to 6 January 2015.

Average alpha diversity was 0.5 ( $\min =0, \max =0.87 ; 1$-Simpson's index) and 1.2 ( $\min =0, \max =2.4$; Shannon's index), with a significant period between 184 and 193 days and an annual period between 312 and 339 days, respectively.

The first two axes of the PCA (Figure 7) explained $61.5 \%$ of the observed variability. The first axis separated C. tanneri from A. fimbria and winter from other seasons. The second axis was associated with decapod shrimps (Hippolytidae) and mysids and separated summer from fall/winter. The overlap between dates of the two principal axes from the different groups can be explained by the temporal continuum between seasons. 


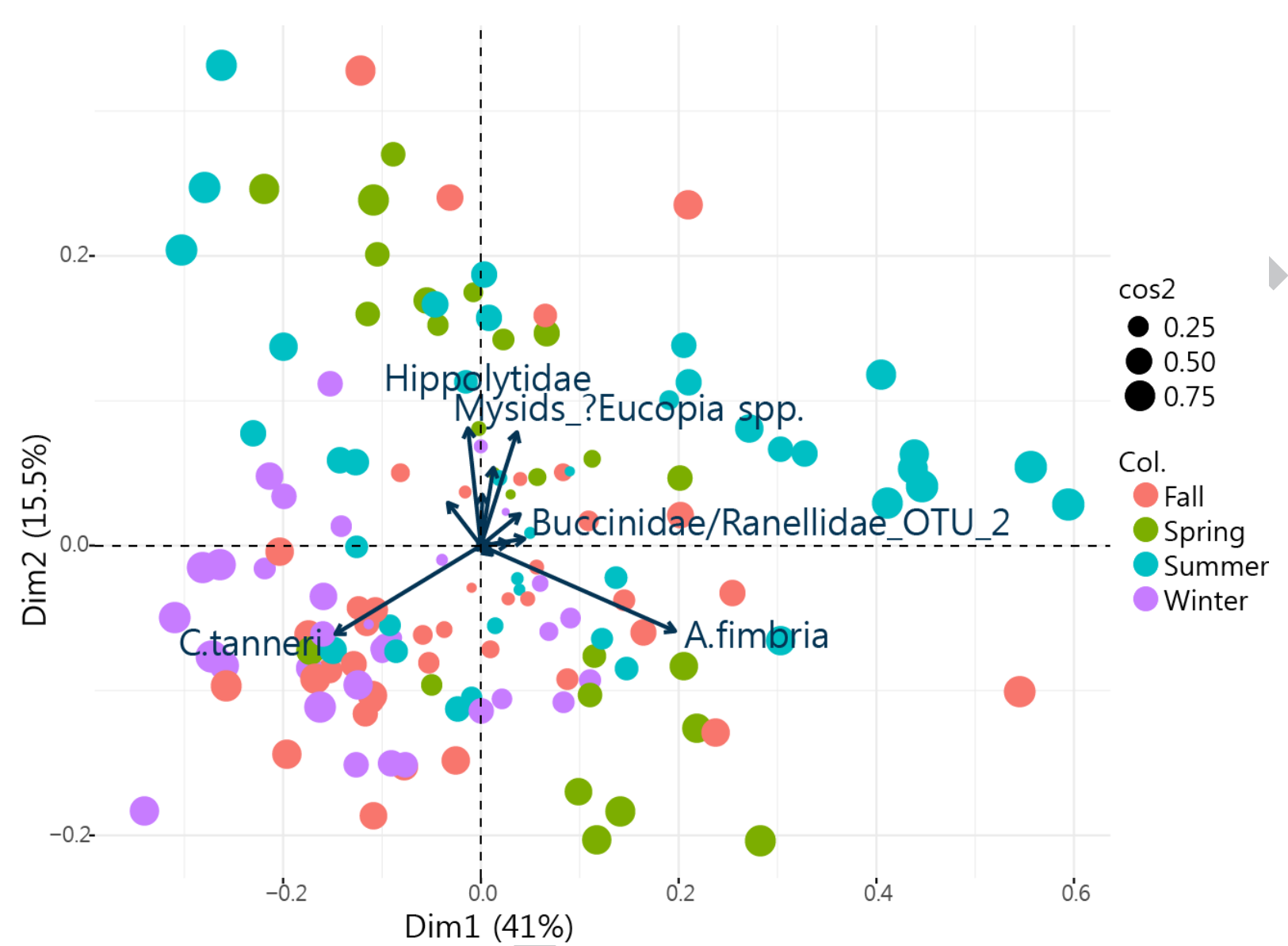

Figure 7: PCA performed on megafaunal density recorded with a stationary video camera from $08 \mathrm{~h} 00$ to $08 \mathrm{~h}$ 05 every day from 17 June 2012 to 6 January 2015 at 985 m depth at the axis of Barkley Canyon (British Columbia, Canada). Daily values were aggregated by week (sum) then transformed according to Hellinger. The arrows represent species that contributed to the observed variance. Species near the origin of the axes were removed to improve clarity. The size of the points is a function of cos2, indicating the quality of its representation on the chosen dimensions.

Environmental influence on community dynamics

Cross correlation analysis showed that weekly values of surface concentration of chlorophyll measured in the region of Barkley canyon were significantly and positively correlated with the density of Buccinidae_OTU_2 (CCF $=0.2$ ) with a lag of 2 months, and with a lag of 5 months with the densities of $C$. tanneri, mysids and $A$. fimbria ( $C C F=0.35,0.30$ and 0.49 respectively).

A total of 196 positive and 651 negative dbMEMs were found. RDA selected the 78 significantly positive dbMEMs that were used to model the faunal matrix. Most of the temporal structure in the variation of community composition was broad scaled (i.e., captured by significant dbMEMs with the 
lowest values), and the remainder was divided between medium and fine scales (Figure 8). Periodograms revealed two cycles with periods of 212 to 243 days and 342 to 346 days for the broad scale sub-model, 46 to 51 days for the medium scale and 8 days for the fine scale (Table 6).

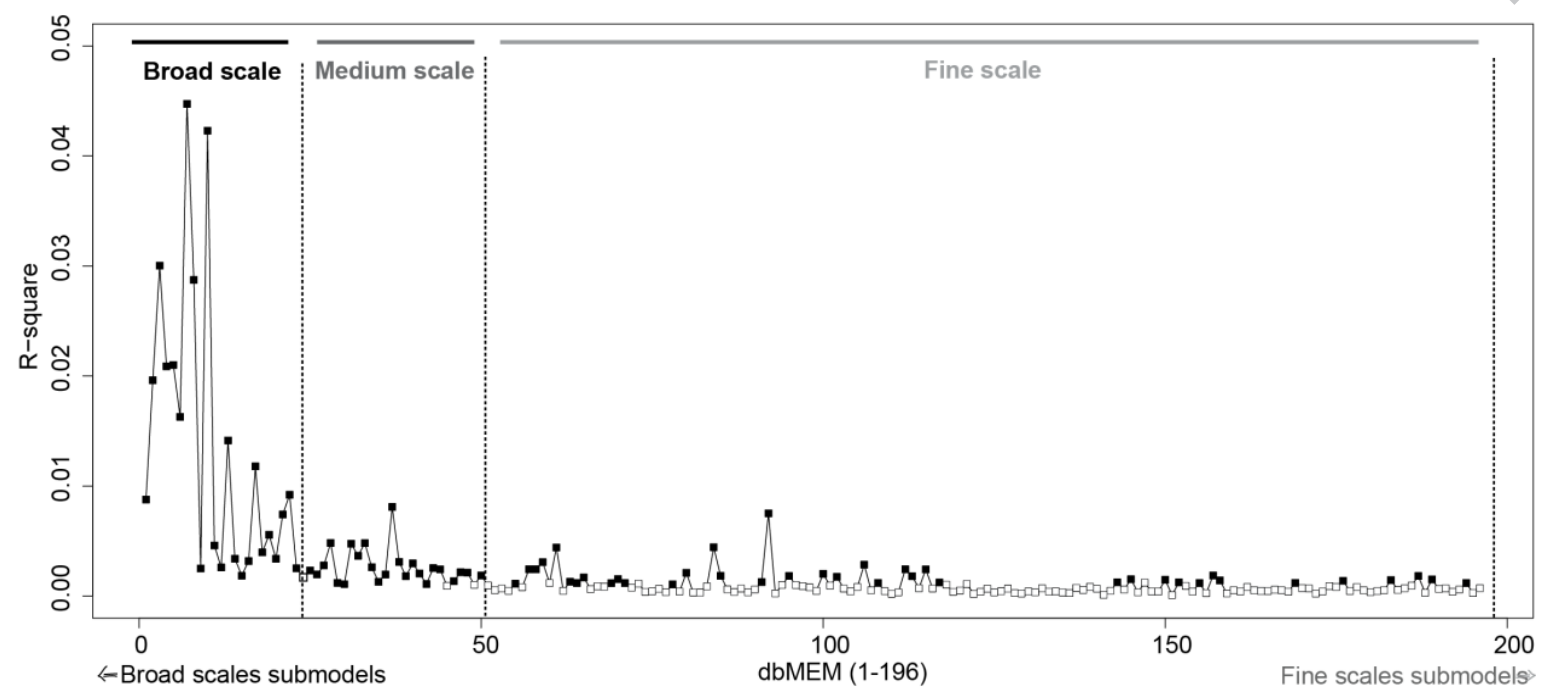

Figure 8: Scalogram illustrating the scaling of temporally structured variation in benthic megafauna community data at the axis of Barkley Canyon (British Columbia, Canada) sampled with a stationary video camera at $985 \mathrm{~m}$ depth every day from $08 \mathrm{~h} 00$ to 08h05 from 17 June 2012 to 6 January 2015. Values on the ordinate are semi-partial $\mathrm{R}^{2}$ (i.e., the variation explained by individual dbMEM variables), computed separately for each dbMEM eigenfunction with positive Moran's I (1-196). The statistics of the dbMEM that were selected by forward selection (i.e. the 78 that significantly contributed to model the faunal response data) are represented by black squares.

The variation partitioning of the megafaunal time series with respect to environmental (i.e. up and cross canyon bottom boundary layer (BBL) current, temperature, wave period, wave height, and wind speed, anomaly of sea surface temperature and sea surface temperature) and MEM model explanatory variables (based on significant positive dbMEMs only) revealed that $61 \%$ of the variation remained unexplained. Only $0.4 \%$ of variation was explained by the exclusive effect of the environmental variables and $8 \%$ by the combined effects of environmental parameters and temporal structure. Thirty percent of variation was explained by the temporal model only. The broad submodel accounted for most of the variation in the community $(27 \%)$, whereas the medium and fine scale sub-models accounted for only 3 and $4 \%$, respectively. Shared effects of environmental factors and the broad-scale sub-model explained $8 \%$ of the variability (all tested factors were significant) 
(Table 6). The combination of wave height, anomaly of sea surface temperature and in situ bottom temperature significantly explained $0.5 \%$ of the medium-scale temporal sub-model and none of the fine-scale sub-model (Table 6). This shift in the benthic community temporal structure and environmental conditions is consistent with the cycle lengths revealed by the periodograms for all environmental factors (between 290 and 400 days). For all species (except Buccinidae_OTU_2), species' density was significantly positively correlated with the ASST (Table 7).

Table 6: $R^{2}$ and probabilities related to the temporal analysis of the epibenthic megafaunal community sampled with a stationary video camera from $08 \mathrm{~h} 00$ to $08 \mathrm{~h} 05$ every day at $985 \mathrm{~m}$ depth at the axis of Barkley Canyon (British Columbia, Canada). First line: $R^{2}$ of each spatial sub-model. Second line: $R^{2}$ of the regression of the submodel (fitted values) on a subset of backward-selected environmental variables. Third line: product of the two previous lines, i.e. variation of the community data explained by the environmental variables at the scale considered. Other lines: $p$-values of the regression coefficients of the environmental variables in the model considered. (*** for $\mathrm{p}$-value $<0.0001$; ${ }^{* *}$ for $\mathrm{p}$-value $<0.05$, / for non-tested as $\mathrm{R}^{2}$ was $=0$ ).

\begin{tabular}{ccccc}
\hline & Axis & Broad & Medium & Fine \\
\hline & community & 212-243 & \multirow{2}{*}{$46-51$} & 8 \\
\hline Significant period (days) & & $342-346$ & & 0.044 \\
\hline $\mathrm{R}^{2}$ adj of dbMEM submodel on axis community & & 0.269 & 0.0373 & 0.0004 \\
$\mathrm{R}^{2}$ adj of environment on submodel & & 0.080 & 0.008 & $/$ \\
$\mathrm{R}^{2}$ adj of environment on axis community & 0.004 & 0.022 & 0.0003 & 0.00001 \\
\hline Wave height & $* * *$ & $* * *$ & $* * *$ & $/$ \\
Wave period & $* * *$ & $* * *$ & & $/$ \\
Anomaly of sea surface temperature & $* * *$ & $* * *$ & $* * *$ & $/$ \\
Sea surface temperature & $* * *$ & $* * *$ & & $/$ \\
Atmospheric pressure & $* * *$ & $* * *$ & & $/$ \\
Along-slope wind & $* * *$ & $* *$ & & $/$ \\
Cross-slope wind & $* *$ & $* *$ & & $/$ \\
Up-canyon boundary layer current & $* *$ & $* *$ & & \\
Cross-canyon boundary layer current & $* *$ & $* *$ & & \\
Temperature & $* * *$ & $* *$ & $* * *$ & \\
\hline
\end{tabular}

Table 7: Results of the correlations performed between daily anomaly of sea surface temperature -calculated using sea surface temperature $\left({ }^{\circ} \mathrm{C}\right)$ measured from 1988 to 2015 at LaPerouse buoy (Tofino, British Columbia, Canada) - and the daily densities of major OTUs observed at $985 \mathrm{~m}$ depth in the axis of Barkley Canyon (British Columbia, Canada) from 17 June 2012 to 11 January 2015. $T$ = Kendall rank correlation coefficient and «ns »= non-significant. 


\begin{tabular}{ccc}
\cline { 2 - 3 } & \multicolumn{2}{c}{ ASST } \\
\hline & $\mathrm{T}$ & $\mathrm{p}$-value \\
\cline { 2 - 3 } A. fimbria & 0.06 & 0.014 \\
C. tanneri & 0.14 & $1.40 \mathrm{e}-09$ \\
Mysids ?Eucopia spp. & 0.17 & $1.60 \mathrm{e}-12$ \\
Buccinidae_OTU_2 & & ns \\
\hline
\end{tabular}




\section{DISCUSSION}

This study is based on long term multidisciplinary data (3 years), sampled at high frequency (daily) at $1000 \mathrm{~m}$ depth in a canyon on a continental margin, and as such addresses repeated recommendations to better understand natural variability of deep-sea ecosystems in an integrated way (Levin et al., 2016; Levin and Le Bris, 2015; Lochte and Pfannkuche, 2002; Markus et al., 2017). The high resolution enabled detection of temporal cycles and structure over a wide range of scales from days to years in environmental and biological data. While previous studies have highlighted the role of tidal-related cycles on animal communities in different deep-sea environments (Cuvelier et al., 2014; Doya et al., 2014; Lelièvre et al., 2017; Wagner et al., 2007), including at Barkley Canyon (Doya et al., 2014; Matabos et al., 2014), most were too short to resolve longer periodic variations, such as seasons, or to validate observations on longer time scales such as inter-annually. However, several factors inherent to the use of fixed deep-sea camera systems limited our ability to generalize our results: the spatially restricted and varying area of sampling $\left(<10 \mathrm{~m}^{2}\right)$, the size of organisms large enough to be visible on video (here $>0.5 \mathrm{~cm}$ ), and the inability to identify species to low taxonomic levels. The structure of the instrument array itself could have influenced organismal behavior and consequently community composition. The use of lights for the camera could disrupt normal behaviors of certain species, such as avoidance of white lights by Anoplopoma fimbria (Widder et al., 2005), or have no influence on others such as for Chionoecetes crabs (Watanabe, 2002). Although Vardaro et al. (2007) showed the absence of a structural effect on abyssal fish and echinoids at 4100 $m$ depth, to our knowledge, no study has been published on taxa known to aggregate, such as crabs (Stevens et al., 1994; Stone et al., 1993) and buccinids (Martell et al., 2002). In any case, any effects related to the presence of the platform are expected to be consistent over time, and changes observed over the 3 years of study to be biologically relevant (Matabos et al., 2012). 


\section{Environmental characterization:}

Weather and sea surface parameters (atmospheric pressure, along and cross-canyon wind, wave height and period and sea surface temperature) showed significant temporal cycles of $\sim 1$ year (300 to 400 days), likely as a result of seasonal variation in surface conditions in the region (Allen et al., 2001; Connolly and Hickey, 2014; Foreman et al., 2011). This intra-annual variation is related to climatic forcing, causing changes in wind and surface currents between summer and winter. The upwelling-favorable wind conditions observed in summer during our study are characteristic of the Northeast Pacific coast and consistent with previous studies conducted in the region (Allen et al., 2001; Hickey, 1997; McFarlane et al., 1997; Tinis et al., 2006). The upwelled, cold, nutrient rich water (Hickey and Banas, 2008; Maclsaac et al., 1985) supports the phytoplankton blooms measured between April and June of each year. During winter, downwelling-favorable conditions (northward, along shelf-break wind) (McFarlane et al., 1997; Tinis et al., 2006), combined with storm events, tend to enhance mixing processes within the upper layer of the water column (Dagg, 1977), in turn increasing downward particle flux (Zùñiga et al., 2009) in canyons. In Barkley canyon, this phenomenon was reported by Thomsen et al., (2017) and also observed in this study. Starting in December, this process can impact the phytoplankton biomass, and the export of primary production on short temporal scales as short phytoplankton pulses followed by low pressure systems are expected to reach our sampling site as pulses of fresh organic matter in 12 to 72 hours (Thomsen et al., 2017).

The axis of the canyon at $985 \mathrm{~m}$ depth is located below the upwelling depth at $250 \mathrm{~m}$ (Allen et al., 2001) and within the core of the Oxygen Minimum Zone (in $\mathrm{OMZ}\left[\mathrm{O}_{2]}<0.5 \mathrm{ml} / \mathrm{l}\right.$ (Domke et al., 2017; L. A. Levin, 2003). The very low oxygen measured over the three years is similar to the one measured a year earlier at the same site (Juniper et al., 2013), supporting a strong inter-annual stability of the $\mathrm{OMZ}$ within the canyon. Annual cycles were also significant in the Bottom Boundary Layer (BBL) suggesting the occurrence of seasonal variation. Mean near-bed flow was 2 to $4 \mathrm{~cm} / \mathrm{s}$, and downcanyon in all seasons and all three years; the variability in current speed relative to this down-canyon 
drift was mainly tidal. Variations on seasonal and semi-annual time scales are barely discernible and, if present, have amplitudes of order $1 \mathrm{~cm} / \mathrm{s}$. The amplitude of seasonal variations in the measured physic-chemical parameters was weak, suggesting that the axis of the canyon is relatively homogeneous in terms of environmental conditions with a local temperature around $5^{\circ} \mathrm{C}$, and a severe hypoxia $(0.30 \mathrm{ml} / \mathrm{L})$.

These homogeneous conditions could however be impacted by the variation in surface chlorophyll concentration through heterogeneous arrivals in quantity and quality of $\mathrm{OM}$ along time in the $\mathrm{BBL}$ of the axis.

\section{Characteristics of the epibenthic megafaunal community in Barkley canyon}

From the 28 OTUs identified, 4 dominated the epibenthic megafaunal community, i.e. the crab Chionoecetes tanneri, the fish Anoplopoma fimbria, mysids (probably Eucopia spp.), and an OTU belonging to buccinid or rannelid family of gastropod. Those results corroborate previous observations in Barkley Canyon (Juniper et al., 2013), and in Monterey canyon (California, USA) around whale falls at 2,018 m depth (Lundsten et al., 2010). Also, ROV surveys confirmed the presence of rannelids gastropods and $C$. tanneri in the core of the $\mathrm{OMZ}$ between $800 \mathrm{~m}$ and $1000 \mathrm{~m}$ depth in the axis of Barkley Canyon (De Leo et al., 2017; Domke et al., 2017). Studies based on IOV survey at the wall of the canyon near cold seeps also confirmed the presence of buccinids gastropod, C. tanneri and A. fimbria but in different proportions than in our observations (Doya et al., 2017). The differences in species composition and observational patterns warrants caution when comparing data recorded with fixed cameras to those from moving platforms (towed camera, IOV, ROV, AUV), especially for highly mobile species. For example, large variation in sampled area prevents us from comparing local (alpha) biodiversity with these studies (Ramirez-Llodra et al., 2010; Vetter et al., 2010). In our study, the dominance of hypoxia-tolerant taxonomic groups associated with only few other taxa, can be explained by low dissolved oxygen concentrations characteristics of OMZ (De Leo et al., 2017). The major taxa found at the axis of the canyon have morphological or physiological 
adaptations to low oxygen concentrations. For example, adults of the sablefish $A$. fimbria exhibit weight-specific oxygen consumption rates which reduce metabolic rates (Sullivan and Smith Jr., 1982), along with large gill surface areas observed among OMZ populations (Friedman et al., 2012). All individuals of the grooved tanner crab C. tanneri appeared to be immature in our study - i.e $<100$ mm (Keller et al., 2016; Workman et al., 2002). No studies exist on physiological or morphological adaptations of $C$. tanneri to hypoxia, but the presence of immature individuals only may suggest that those stages are less sensitive to low oxygen. A higher resistance of juveniles has been observed in gastropods (Vosloo et al., 2013), but juveniles of different crustacean species, such as shrimps and blue crabs, avoid hypoxic regions altogether (Stickle et al., 1989). Alternatively, immature crabs may be using the canyon as shelter from predation by large fish that avoid the $\mathrm{OMZ}$ as they are more vulnerable and less foraging-efficient in hypoxia (Ekau et al., 2010; Pollock et al., 2007). Mysids can show important ventilation associated with larger gills and efficient respiratory pigment when found in a hypoxic area (Levin, 2002; Sanders and Childress, 1990). Buccinidae and ranellidae can endure low oxygen levels (Theede, 1973) and are commonly found in hypoxic zones, for example Jerrybuccinum kantori in the Chilean coast (Fraussen et al., 2014), Neptuna spp in Monterey Bay (California) (Braby et al., 2007) and Fusitriton oregonensis in Barkley Canyon (De Leo et al., 2017; Domke et al., 2017).

\section{Scales of variation in the community dynamics}

Temporal structure explained $35 \%$ of the variance in the epibenthic megafaunal community in Barkley Canyon. Most of this variance (i.e. 27\%) corresponded to a broad scale of $225(+/-15)$ and $344(+/-4)$ days, most likely an annual cycle that we hypothesized is related to seasonal variation. This hypothesis is strengthened by the highly significant correlation between the broad temporal scale and all measured surface and benthic boundary layer (BBL) hydrographic conditions. While analyses do not provide information on the mechanisms behind the observed dynamics, results suggest a strong influence of surface primary production. This hypothesis was supported by the strong link between all major species and the surface chlorophyll concentration with a lag of 2 to 5 
months. Despite the lack of quantitative measurements of the input in organic material, peaks in primary production recorded at the surface are expected to impact and reach the BBL in the axis of Barkley Canyon (Campanyà-Llovet et al., submitted; Thomsen et al., 2017). Indeed fresh organic material of phytoplanktonic and zooplanktonic origin was found around $800 \mathrm{~m}$ depth in Barkley Canyon and attributed to different sources: (i) sinking of phytoplankton from the surface and resuspended material from shallower sites and, (ii) overwintering migration of copepods (CampanyàLlovet et al., submitted). The amount and timing of surface production reaching these depths in the canyon will depend on topography and resuspension events under elevated flow ( Thomsen et al., 2017). In our study, only $8 \%$ of the broad scale temporal sub-model is explained by the measured environmental conditions. But because of the difference in temporal sampling rates, the surface production was not included in the analyses. Thus, part of the remaining variance could be attributed to the surface production, but also to other processes such as biotic interactions (e.g. predation, reproduction), occurring on seasonal scales. For instance, the intra-annual variation in crab density might reflect spatial movement of the population in response to resource availability. The seasonal increase in the density of juvenile of Chionoecetes tanneri in June and October, likely also observed shallower on the canyon wall (Doya et al., 2017), might be related to the arrival of the spring and summer surface phytoplankton blooms. Immature tanner crabs feed mostly on zooplankton (Phillips and Lauzier, 1997), accounting for the positive correlation with the planktonic group, which also increases during blooms (Burghart et al., 2010; Fulmer and Bollens, 2005; Roe, 1984). In addition, seasonal reproduction matching the timing of the spring bloom could explain the recruitment of young crabs in fall, in an area where they find refuge from predation. The seasonal pattern in faunal distribution we observed supports the hypothesis of seasonality proposed by Juniper et al. (2013) after a year of observations on the wall of Barkley Canyon. Similarly to our observations, those authors also noted that some species showed no temporal patterns but occurred throughout the year. The absence of a seasonal signal in the abundance of the sablefish A. fimbria could be related to their high mobility (Sullivan and Smith Jr., 1982). Their opportunistic predatory behavior may 
explain the absence of an annual temporal pattern in abundance (Friedman et al., 2012; Sullivan and Somero, 1980). Over the three years, the combination of both environmental conditions and temporal components explained $39 \%$ of the variation in megafaunal community, suggesting the important role of factors, such as other environmental variables, biotic interactions, life-history traits, and stochastic events and random processes.

In autumn 2014, a sudden increase in the density of $C$. tanneri was concomitant with higher variability in density of $A$. fimbria and ?Eucopia spp., and a spring/summer peak in surface chlorophyll concentration. The high surface primary production observed in summer 2014, was associated with a greater daily anomaly in sea surface temperature compared to previous years. This phenomenon coincided with the "Blob", i.e. the strongest temperature anomaly event recorded since the 1980s, which started in winter 2013-2014 in the NE Pacific Ocean, characterized by warm surface temperature $\left(2^{\circ} \mathrm{C}\right.$ above average near-surface temperature anomalies), and a shallower mixed layer (5 to $10 \mathrm{~m}$ shallower) (Bond et al., 2015). Those abnormal values were observed until the end of 2014. Our results suggest that species in the canyon indirectly responded to this climatic anomaly through increased resource availability. Alternatively, the suppression of nutrient transport into the mixed layer (Bond et al., 2015) could have affected the diel vertical migration of the mysid prey and in turn alter their behavior and probably that of other zooplankton species. However, the processes and mechanisms underlying this community response remain to be determined. The trend observed in this study underlines the need to monitor future changes in environmental conditions in the region and the associated ecological responses. The combined effect of expansion of OMZs (Whitney et al., 2007) and surface temperature warming in response to global change might precipitate the system into an alternative state with strongly modified community structure and ecosystem functions (Scheffer et al., 2001) if the system reaches its tipping point (van Nes et al., 2016). 


\section{CONCLUSION}

This study revealed that the benthic community at $1000 \mathrm{~m}$ depth on the axis of Barkley Canyon is mainly composed of taxa adapted to severe hypoxic conditions and of, at least, two species of commercial interest: Chionoectes tanneri and Anoplopoma fimbria. The community exhibited an annual cycle in density that can be partly attributed to seasonal changes in sea surface weather and hydrographic conditions both at the sea surface and in the benthic boundary layer. Transport of nutrients from the sea surface to the seafloor is suggested to be the main mechanism regulating community dynamics. Despite strong seasonal trends, environmental conditions at $980 \mathrm{~m}$ depth on the axis of Barkley Canyon are homogeneous over the year, allowing species to adapt to this hypoxic environment. Lastly, an increase in the sea surface temperature anomaly attributed to the 'BLOB' led to changes in the benthic community composition, probably in response to an increase in surface production and/or a modification in nutrient transport. Our results underscore the need for longterm monitoring in the region, and a better understanding of ecosystem resilience to impacts related to climate change.

\section{BIBLIOGRAPHY}

Aguzzi, J., 2011. Activity rhythms in the deep-sea: a chronobiological approach. Frontiers in Bioscience 16, 131. https://doi.org/10.2741/3680

Allen, S.E., Durrieu de Madron, X., 2009. A review of the role of submarine canyons in deep-ocean exchange with the shelf. Ocean Science 5, 607-620.

Allen, S.E., Vindeirinho, C., Thomson, R.E., Foreman, M.G.G., Mackas, D.L., 2001. Physical and biological processes over a submarine canyon during an upwelling event. Canadian Journal of Fisheries and Aquatic Sciences 58, 671-684. https://doi.org/10.1139/cjfas-58-4-671 
Aller, J.Y., Stupakoff, I., 1996. The distribution and seasonal characteristics of benthic communities on the Amazon shelf as indicators of physical processes. Continental Shelf Research 16, 717751.

Almeida, M., Frutos, I., Company, J.B., Martin, D., Romano, C., Cunha, M.R., 2017. Biodiversity of suprabenthic peracarid assemblages from the Blanes Canyon region (NW Mediterranean Sea) in relation to natural disturbance and trawling pressure. Deep Sea Research Part II: Topical Studies in Oceanography 137, 390-403. https://doi.org/10.1016/j.dsr2.2016.06.019

Blanchard, A.L., Feder, H.M., Hoberg, M.K., 2010. Temporal variability of benthic communities in an Alaskan glacial fjord, 1971-2007. Marine Environmental Research 69, 95-107. https://doi.org/10.1016/j.marenvres.2009.08.005

Bograd, S.J., Castro, C.G., Di Lorenzo, E., Palacios, D.M., Bailey, H., Gilly, W., Chavez, F.P., 2008. Oxygen declines and the shoaling of the hypoxic boundary in the California Current: HYPOXIA IN THE CALIFORNIA CURRENT. Geophysical Research Letters 35, n/a-n/a. https://doi.org/10.1029/2008GL034185

Bond, N.A., Cronin, M.F., Freeland, H., Mantua, N., 2015. Causes and impacts of the 2014 warm anomaly in the NE Pacific: 2014 WARM ANOMALY IN THE NE PACIFIC. Geophysical Research Letters 42, 3414-3420. https://doi.org/10.1002/2015GL063306

Borcard, D., Gillet, F., Legendre, P., 2011. Cluster Analysis, in: Numerical Ecology with R. Springer New York, New York, NY, pp. 53-114.

Borcard, D., Legendre, P., 2002. All-scale spatial analysis of ecological data by means of principal coordinates of neighbour matrices. Ecological Modelling 153, 51-68.

Borcard, D., Legendre, P., Avois-Jacquet, C., Tuomisto, H., 2004. Dissecting the spatial structure of ecological data at multiple scales. Ecology 85, 1826-1832.

Braby, C.E., Rouse, G.W., Johnson, S.B., Jones, W.J., Vrijenhoek, R.C., 2007. Bathymetric and temporal variation among Osedax boneworms and associated megafauna on whale-falls in Monterey 
Bay, California. Deep Sea Research Part I: Oceanographic Research Papers 54, 1773-1791. https://doi.org/10.1016/j.dsr.2007.05.014

Burghart, S., Hopkins, T., Torres, J., 2010. Partitioning of food resources in bathypelagic micronekton in the eastern Gulf of Mexico. Marine Ecology Progress Series 399, 131-140. https://doi.org/10.3354/meps08365

Campanyà-Llovet, N., Snelgrove, P., De Leo, F.C., submitted. Food quantity and quality in Barkley Canyon (NE Pacific) and its influence on the macroinfaunal community structure. Progress in Oceanography.

Chan, F., Barth, J.A., Lubchenco, J., Kirincich, A., Weeks, H., Peterson, W.T., Menge, B.A., 2008. Emergence of Anoxia in the California Current Large Marine Ecosystem. Science 319, 920920. https://doi.org/10.1126/science.1149016

Connolly, T.P., Hickey, B.M., 2014. Regional impact of submarine canyons during seasonal upwelling. Journal of Geophysical Research: Oceans 119, 953-975. https://doi.org/10.1002/2013JC009452

Cuvelier, D., Legendre, P., Laes, A., Sarradin, P.-M., Sarrazin, J., 2014. Rhythms and Community Dynamics of a Hydrothermal Tubeworm Assemblage at Main Endeavour Field - A Multidisciplinary Deep-Sea Observatory Approach. PLoS ONE 9, e96924. https://doi.org/10.1371/journal.pone.0096924

Dagg, M., 1977. Some effects of patchy food environments on copepods1: Patchy food $\begin{array}{llll}\text { environments. Limnology } \quad \text { Ond } & \text { Oceanography }\end{array}$ https://doi.org/10.4319/lo.1977.22.1.0099

De Leo, F.C., Drazen, J.C., Vetter, E.W., Rowden, A.A., Smith, C.R., 2012. The effects of submarine canyons and the oxygen minimum zone on deep-sea fish assemblages off Hawai'i. Deep Sea Research Part I: Oceanographic Research Papers 64, 54-70. https://doi.org/10.1016/j.dsr.2012.01.014 
De Leo, F.C., Gauthier, M., Nephin, J., Mihály, S., Juniper, S.K., 2017. Bottom trawling and oxygen minimum zone influences on continental slope benthic community structure off Vancouver Island (NE Pacific). Deep Sea Research Part II: Topical Studies in Oceanography 137, 404-419. https://doi.org/10.1016/j.dsr2.2016.11.014

De Leo, F.C., Vetter, E.W., Smith, C.R., Rowden, A.A., McGranaghan, M., 2014. Spatial scaledependent habitat heterogeneity influences submarine canyon macrofaunal abundance and diversity off the Main and Northwest Hawaiian Islands. Deep Sea Research Part II: Topical Studies in Oceanography 104, 267-290. https://doi.org/10.1016/j.dsr2.2013.06.015

De'Ath, G., 2002. Multivariate regression trees: a new technique for modeling species-environment relationships. Ecology 83, 1105-1117.

Domke, L., Lacharité, M., Metaxas, A., Matabos, M., 2017. Influence of an oxygen minimum zone and macroalgal enrichment on benthic megafaunal community composition in a NE Pacific submarine canyon. Marine Ecology 38. https://doi.org/10.1111/maec.12481

Doya, C., Aguzzi, J., Pardo, M., Matabos, M., Company, J.B., Costa, C., Mihaly, S., Canals, M., 2014. Diel behavioral rhythms in sablefish (Anoplopoma fimbria) and other benthic species, as recorded by the Deep-sea cabled observatories in Barkley canyon (NEPTUNE-Canada). Journal of Marine Systems 130, 69-78. https://doi.org/10.1016/j.jmarsys.2013.04.003

Doya, C., Chatzievangelou, D., Bahamon, N., Purser, A., De Leo, F.C., Juniper, S.K., Thomsen, L., Aguzzi, J., 2017. Seasonal monitoring of deep-sea megabenthos in Barkley Canyon cold seep by internet operated vehicle (IOV). PLOS ONE 12, e0176917. https://doi.org/10.1371/journal.pone.0176917

Dray, S., Legendre, P., Peres-Neto, P.R., 2006. Spatial modelling: a comprehensive framework for principal coordinate analysis of neighbour matrices (PCNM). Ecological Modelling 196, 483493. https://doi.org/10.1016/j.ecolmodel.2006.02.015 
Duineveld, G., Lavaleye, M., Berghuis, E., De Wilde, P., 2001. Activity and composition of the benthic fauna in the Whittard Canyon and the adjacent continental slope (NE Atlantic). Oceanologica Acta 24, 69-83.

Ekau, W., Auel, H., Pörtner, H.-O., Gilbert, D., 2010. Impacts of hypoxia on the structure and processes in pelagic communities (zooplankton, macro-invertebrates and fish). Biogeosciences 7, 1669-1699. https://doi.org/10.5194/bg-7-1669-2010

Farrugio, H., 2012. A refugium for the spawners of exploited Mediterranean marine species: the canyons of the continental slope of the Gulf of Lion. Mediterranean Submarine Canyons: Ecology and Governance 45-49.

Fernandez-Arcaya, U., Ramirez-Llodra, E., Aguzzi, J., Allcock, A.L., Davies, J.S., Dissanayake, A., Harris, P., Howell, K., Huvenne, V.A.I., Macmillan-Lawler, M., Martín, J., Menot, L., Nizinski, M., Puig, P., Rowden, A.A., Sanchez, F., Van den Beld, I.M.J., 2017. Ecological Role of Submarine Canyons and Need for Canyon Conservation: A Review. Frontiers in Marine Science 4. https://doi.org/10.3389/fmars.2017.00005

Fernandez-Arcaya, U., Rotllant, G., Ramirez-Llodra, E., Recasens, L., Aguzzi, J., Flexas, M.M., SanchezVidal, A., López-Fernández, P., García, J.A., Company, J.B., 2013. Reproductive biology and recruitment of the deep-sea fish community from the NW Mediterranean continental $\begin{array}{llll}\text { margin. } & \text { Progress }\end{array}$ https://doi.org/10.1016/j.pocean.2013.07.019

Foreman, M.G.G., Pal, B., Merryfield, W.J., 2011. Trends in upwelling and downwelling winds along the British Columbia shelf. Journal of Geophysical Research 116. https://doi.org/10.1029/2011JC006995

Fraussen, K., Sellanes, J., Stahlschmidt, P., 2014. The South American radiation of Jerrybuccinum (Gastropoda, Buccinidae), with a new deep-water species from Chile. ZooKeys 409, 61-70. https://doi.org/10.3897/zookeys.409.7194 
Freeland, H.J., Crawford, W.R., Thomson, R.E., 1984. Currents along the pacific coast of Canada. Atmosphere-Ocean 22, 151-172. https://doi.org/10.1080/07055900.1984.9649191

Friedman, J.R., Condon, N.E., Drazen, J.C., 2012. Gill surface area and metabolic enzyme activities of demersal fishes associated with the oxygen minimum zone off California. Limnology and Oceanography 57, 1701-1710. https://doi.org/10.4319/lo.2012.57.6.1701

Fulmer, J.H., Bollens, S.M., 2005. Responses of the chaetognath, Sagitta elegans, and larval Pacific hake, Merluccius productus, to spring diatom and copepod blooms in a temperate fjord (Dabob Bay, Washington). Progress in Oceanography 67, 442-461. https://doi.org/10.1016/j.pocean.2005.09.010

Gage, J.D., Lamont, P.A., Tyler, P.A., 1995. Deep-Sea Macrobenthic Communities at Contrasting Sites off Portugal, Preliminary Results: I Introduction and Diversity Comparisons. Internationale Revue der gesamten Hydrobiologie und Hydrographie 80, 235-250. https://doi.org/10.1002/iroh.19950800211

Goffredi, S.K., Paull, C.K., Fulton-Bennett, K., Hurtado, L.A., Vrijenhoek, R.C., 2004. Unusual benthic fauna associated with a whale fall in Monterey Canyon, California. Deep Sea Research Part I: Oceanographic Research Papers 51, 1295-1306. https://doi.org/10.1016/j.dsr.2004.05.009

Gooday, A.J., 2002. Biological responses to seasonally varying fluxes of organic matter to the ocean floor: a review. Journal of Oceanography 58, 305-332.

Granata, T.C., Estrada, M., Zika, U., Merry, C., 2004. Evidence for enhanced primary production resulting from relative vorticity induced upwelling in the Catalan Current. Scientia Marina 68, 113-119. https://doi.org/10.3989/scimar.2004.68s1113

Grantham, B.A., Chan, F., Nielsen, K.J., Fox, D.S., Barth, J.A., Huyer, A., Lubchenco, J., Menge, B.A., 2004. Upwelling-driven nearshore hypoxia signals ecosystem and oceanographic changes in the northeast Pacific. Nature 429, 749-754. https://doi.org/10.1038/nature02605

Griffith, D.A., Peres-Neto, P.R., 2006. Spatial modeling in ecology: the flexibility of eigenfunction spatial analyses. Ecology 87, 2603-2613. 
Harris, P.T., Macmillan-Lawler, M., Rupp, J., Baker, E.K., 2014. Geomorphology of the oceans. Marine Geology 352, 4-24. https://doi.org/10.1016/j.margeo.2014.01.011

Harris, P.T., Whiteway, T., 2011. Global distribution of large submarine canyons: Geomorphic differences between active and passive continental margins. Marine Geology 285, 69-86. https://doi.org/10.1016/j.margeo.2011.05.008

Hickey, B.M., 1997. The Response of a Steep-Sided, Narrow Canyon to Time-Variable Wind Forcing. Journal of Physical Oceanography 27, 697-726. https://doi.org/10.1175/15200485(1997)027<0697:TROASS>2.0.CO;2

Hickey, B.M., Banas, N., 2008. Why is the Northern End of the California Current System So Productive? Oceanography 21, 90-107. https://doi.org/10.5670/oceanog.2008.07

IHO, 2013. Standardization of Undersea Feature Names: Guidelines Proposal form Terminology, 4.1th ed. International Hydrographic Organisation and Intergovernmental Oceanographic Commission, Monaco.

Juniper, S.K., Matabos, M., Mihály, S., Ajayamohan, R.S., Gervais, F., Bui, A.O.V., 2013. A year in Barkley Canyon: A time-series observatory study of mid-slope benthos and habitat dynamics using the NEPTUNE Canada network. Deep Sea Research Part II: Topical Studies in Oceanography 92, 114-123. https://doi.org/10.1016/j.dsr2.2013.03.038

Keller, A.A., Buchanan, J.C., Steiner, E., Draper, D., Chappell, A., Frey, P., Head, M.A., 2016. Size at maturity for grooved Tanner crab (Chionoecetes tanneri ) along the U.S. west coast (Washington to California). Fisheries Oceanography 25, 292-305. https://doi.org/10.1111/fog.12155

Legendre, P., Gallagher, E., 2001. Ecologically meaningful transformations for ordination of species data. Oecologia 129, 271-280. https://doi.org/10.1007/s004420100716

Legendre, P., Gauthier, O., 2014. Statistical methods for temporal and space-time analysis of community composition data. Proceedings of the Royal Society B: Biological Sciences 281, 20132728-20132728. https://doi.org/10.1098/rspb.2013.2728 
Legendre, P., Legendre, L., 2012. Numerical ecology. 3rd English Edition., Elsevier Ed. ed.

Legendre, P., Legendre, L., 1998. Numerical ecology, 2nd English edition, Elsevier Science BV, Amsterdam. ed.

Lelièvre, Y., Legendre, P., Matabos, M., Mihaly, S., Lee, R.W., Sarradin, P.-M., Arango, C.P., Sarrazin, J., 2017. Astronomical and atmospheric impacts on deep-sea hydrothermal vent invertebrates. Proceedings of the Royal Society B: Biological Sciences 284, 20162123. https://doi.org/10.1098/rspb.2016.2123

Levin, L.A., 2003. Oxygen minimum zone benthos: adaptation and community response to hypoxia. Oceanography and Marine Biology: An Annual Review 41, 1-45.

Levin, L.A., 2003. Oxygen minimum zone benthos: adaptation and community response to hypoxia. Oceanography and Marine Biology: An Annual Review 41, 1-45.

Levin, L.A., 2002. Deep-Ocean Life Where Oxygen Is Scarce. American Scientist 90, 436. https://doi.org/10.1511/2002.5.436

Levin, L.A., Le Bris, N., 2015. The deep ocean under climate change. Science 350, 766-768. https://doi.org/10.1126/science.aad0126

Levin, L.A., Le Bris, N., Cordes, E., Eddebbar, Y., Jeffreys, R.M., Sato, K.N., Wei, C.-L., 2016. A Case for the Deep Ocean. DOSI Deep-Ocean Stewardship Initiative 1-4.

Lochte, K., Pfannkuche, O., 2002. Processes driven by the Small Sized Organisms at the WaterSediment Interface, in: Wefer, G., Billett, D., Hebbeln, D., Jørgensen, B.B., Schlüter, M., van Weering, T.C.E. (Eds.), Ocean Margin Systems. Springer Berlin Heidelberg, Berlin, Heidelberg, pp. $405-418$.

López Abellán, L.J., Balguerías, E., Fernández-Vergaz, V., 2002. Life history characteristics of the deepsea crab Chaceon affinis population off Tenerife (Canary Islands). Fisheries Research 58, 231239. https://doi.org/10.1016/S0165-7836(01)00384-8

Lundsten, L., Schlining, K.L., Frasier, K., Johnson, S.B., Kuhnz, L.A., Harvey, J.B.J., Clague, G., Vrijenhoek, R.C., 2010. Time-series analysis of six whale-fall communities in Monterey 
Canyon, California, USA. Deep Sea Research Part I: Oceanographic Research Papers 57, 15731584. https://doi.org/10.1016/j.dsr.2010.09.003

Macdonald, R.W., Wong, C.S., Erickson, P.E., 1987. The distribution of nutrients in the southeastern Beaufort Sea: Implications for water circulation and primary production. Journal of Geophysical Research 92, 2939. https://doi.org/10.1029/JC092iC03p02939

Maclsaac, J.J., Dugdale, R.C., Barber, R.T., Blasco, D., Packard, T.T., 1985. Primary production cycle in an upwelling center. Deep Sea Research Part A. Oceanographic Research Papers 32, 503-529. https://doi.org/10.1016/0198-0149(85)90042-1

Markus, T., Hillebrand, H., Hornidge, A.-K., Krause, G., Schluter, A., 2017. Disciplinary diversity in marine sciences: the urgent case for an integration of research. ICES Journal of Marine Science. https://doi.org/10.1093/icesjms/fsx201

Martell, K.A., Tunnicliffe, V., Macdonald, I.R., 2002. Biological features of a buccinid whelk (gastropoda, neogastropoda) at the endeavour ventfields of Juan de Fuca ridge, northeast pacific. Journal Molluscan Studies 68, 45-53. https://doi.org/10.1093/mollus/68.1.45

Martín, J., Puig, P., Masqué, P., Palanques, A., Sánchez-Gómez, A., 2014. Impact of Bottom Trawling on Deep-Sea Sediment Properties along the Flanks of a Submarine Canyon. PLoS ONE 9, e104536. https://doi.org/10.1371/journal.pone.0104536

Matabos, M., Bui, A.O.V., Mihály, S., Aguzzi, J., Juniper, S.K., Ajayamohan, R.S., 2014. High-frequency study of epibenthic megafaunal community dynamics in Barkley Canyon: A multi-disciplinary approach using the NEPTUNE Canada network. Journal of Marine Systems 130, 56-68. https://doi.org/10.1016/j.jmarsys.2013.05.002

Matabos, M., Tunnicliffe, V., Juniper, S.K., Dean, C., 2012. A Year in Hypoxia: Epibenthic Community Responses to Severe Oxygen Deficit at a Subsea Observatory in a Coastal Inlet. PLoS ONE 7, e45626. https://doi.org/10.1371/journal.pone.0045626 
McClain, C.R., Barry, J.P., 2010. Habitat heterogeneity, disturbance, and productivity work in concert to regulate biodiversity in deep submarine canyons. Ecology 91, 964-976. https://doi.org/10.1890/09-0087.1

McFarlane, G.A., Ware, G.A., Thomson, R.E., Mackas, D.L., Robinson, C.L.K., 1997. Physical, biological and fisheries oceanography of a large ecosystem (west coast of Vancouver Island) and implications for management. Oceanologica Acta 20, 191-200.

Nittrouer, C.A., Wright, D.L., 1994. Transport of particles across continental shelves. Reviews of Geophysics 32, 85. https://doi.org/10.1029/93RG02603

Okey, T.A., 1997. Sediment flushing observations, earthquake slumping, and benthic community changes in Monterey Canyon head. Continental Shelf Research 17, 877-897. https://doi.org/10.1016/S0278-4343(96)00067-2

Paine, M.D., DeBlois, E.M., Kilgour, B.W., Tracy, E., Pocklington, P., Crowley, R.D., Williams, U.P., Gregory Janes, G., 2014. Effects of the Terra Nova offshore oil development on benthic macro-invertebrates over 10 years of development drilling on the Grand Banks of Newfoundland, Canada. Deep Sea Research Part II: Topical Studies in Oceanography 110, 3864. https://doi.org/10.1016/j.dsr2.2014.10.015

Peres-Neto, P.R., Legendre, P., 2010. Estimating and controlling for spatial structure in the study of ecological communities: Spatial structure in ecological communities. Global Ecology and Biogeography 19, 174-184. https://doi.org/10.1111/j.1466-8238.2009.00506.x

Phillips, A.C., Lauzier, R.B., 1997. Biological background for the development of a new fishery for the grooved Tanner crab (Chionoecetes tannen) of British Columbia. Canadian Stock Assessment Secretariat Research Document 97/148, 1-81.

Pollock, M.S., Clarke, L.M.J., Dubé, M.G., 2007. The effects of hypoxia on fishes: from ecological relevance to physiological effects. Environmental Reviews 15, 1-14. https://doi.org/10.1139/a06-006 
Puig, P., Company, J.B., Sardà, F., Palanques, A., 2001. Responses of deep-water shrimp populations to intermediate nepheloid layer detachments on the Northwestern Mediterranean continental margin. Deep Sea Research Part I: Oceanographic Research Papers 48, 21952207. https://doi.org/10.1016/S0967-0637(01)00016-4

Puig, P., Martín, J., Masqué, P., Palanques, A., 2015. Increasing sediment accumulation rates in La Fonera (Palamós) submarine canyon axis and their relationship with bottom trawling activities: Trawling Effects on Sedimentation Rates. Geophysical Research Letters 42, 81068113. https://doi.org/10.1002/2015GL065052

Puig, P., Palanques, A., Martín, J., 2014. Contemporary Sediment-Transport Processes in Submarine Canyons. Annual Review of Marine Science 6, 53-77. https://doi.org/10.1146/annurevmarine-010213-135037

Rádková, V., Bojková, J., Křoupalová, V., Schenková, J., Syrovátka, V., Horsák, M., 2014. The role of dispersal mode and habitat specialisation in metacommunity structuring of aquatic macroinvertebrates in isolated spring fens. Freshwater Biology 59, 2256-2267. https://doi.org/10.1111/fwb.12428

Ramirez-Llodra, E., Brandt, A., Danovaro, R., De Mol, B., Escobar, E., German, C.R., Levin, L.A., Martinez Arbizu, P., Menot, L., Buhl-Mortensen, P., Narayanaswamy, B.E., Smith, C.R., Tittensor, D.P., Tyler, P.A., Vanreusel, A., Vecchione, M., 2010. Deep, diverse and definitely different: unique attributes of the world's largest ecosystem. Biogeosciences 7, 2851-2899. https://doi.org/10.5194/bg-7-2851-2010

Ramirez-Llodra, E., Tyler, P.A., Baker, M.C., Bergstad, O.A., Clark, M.R., Escobar, E., Levin, L.A., Menot, L., Rowden, A.A., Smith, C.R., Van Dover, C.L., 2011. Man and the Last Great Wilderness: Human Impact on the Deep Sea. PLoS ONE 6, e22588. https://doi.org/10.1371/journal.pone.0022588 
Roe, H.S.J., 1984. The diel migrations and distributions within a Mesopelagic community in the North East Atlantic. 2. Vertical migrations and feeding of Mysids and decapod crustacea. Progress in Oceanography 13, 269-318. https://doi.org/10.1016/0079-6611(84)90011-9

Ross, S.W., Rhode, M., Quattrini, A.M., 2015. Demersal fish distribution and habitat use within and near Baltimore and Norfolk Canyons, U.S. middle Atlantic slope. Deep Sea Research Part I: Oceanographic Research Papers 103, 137-154. https://doi.org/10.1016/j.dsr.2015.06.004

Ruhl, H.A., 2004. Shifts in Deep-Sea Community Structure Linked to Climate and Food Supply. Science 305, 513-515. https://doi.org/10.1126/science.1099759

Ryan, J.P., Chavez, F.P., Bellingham, J.G., 2005. Physical-biological coupling in Monterey Bay, California: topographic influences on phytoplankton ecology. Marine Ecology Progress Series $287,23-32$.

Sanders, N.K., Childress, J.J., 1990. Adaptations to the Deep-Sea Oxygen Minimum Layer: Oxygen Binding by the Hemocyanin of the Bathypelagic Mysid, Gnathophausia ingens Dohrn. The Biological Bulletin 178, 286-294. https://doi.org/10.2307/1541830

Sbragaglia, V., Lamanna, F., M. Mat, A., Rotllant, G., Joly, S., Ketmaier, V., de la Iglesia, H.O., Aguzzi, J., 2015. Identification, Characterization, and Diel Pattern of Expression of Canonical Clock Genes in Nephrops norvegicus (Crustacea: Decapoda) Eyestalk. PLOS ONE 10, e0141893. https://doi.org/10.1371/journal.pone.0141893

Scheffer, M., Carpenter, S., Foley, J.A., Folke, C., Walker, B., 2001. Catastrophic shifts in ecosystems. Nature 413, 591.

Stevens, B.G., Haaga, J.A., Donaldson, W.E., 1994. Aggregative Mating of Tanner Crabs, Chionoecetes bairdi. Canadian Journal of Fisheries and Aquatic Sciences 51, 1273-1280. https://doi.org/10.1139/f94-127

Stickle, W.B., Kapper, M.A., Liu, L.-L., Gnaiger, E., Wang, S.Y., 1989. Metabolic adaptations of several species of Crustaceans and Molluscs to hypoxia: tolerance and microcalorimetric studies. The Biological Bulletin 177, 303-312. https://doi.org/10.2307/1541945 
Stone, R.P., O'Clair, C.E., Shirley, T.C., 1993. Aggregating Behavior of Ovigerous Female Red King Crab, Paralithodes camtschaticus, in Auke Bay, Alaska. Canadian Journal of Fisheries and Aquatic Sciences 50, 750-758. https://doi.org/10.1139/f93-086

Sullivan, K.M., Smith Jr., K.L., 1982. Energetics of Sablefish, Anoplopoma fimbria , under Laboratory Conditions. Canadian Journal of Fisheries and Aquatic Sciences 39, 1012-1020. https://doi.org/10.1139/f82-136

Sullivan, K.M., Somero, G.N., 1980. Enzyme activities of fish skeletal muscle and brain as influenced by depth of occurrence and habits of feeding and locomotion. Marine Biology 60, 91-99. https://doi.org/10.1007/BF00389152

Theede, H., 1973. Comparative studies on the influence of oxygen deficiency and hydrogen sulphide on marine bottom invertebrates. Netherlands Journal of Sea Research 7, 244-252. https://doi.org/10.1016/0077-7579(73)90048-3

Thomsen, L., Aguzzi, J., Costa, C., De Leo, F., Ogston, A., Purser, A., 2017. The Oceanic Biological Pump: Rapid carbon transfer to depth at Continental Margins during Winter. Scientific Reports 7. https://doi.org/10.1038/s41598-017-11075-6

Tinis, S.W., Thomson, R.E., Mass, C.F., Hickey, B.M., 2006. Comparison of MM5 and meteorological buoy winds from British Columbia to Northern California. Atmosphere-Ocean 44, 65-81. https://doi.org/10.3137/ao.440105

Tyler, P.A., 1988. Seasonality in the deep sea. Oceanography and Marine Biology: An Annual Review $26,227-258$.

Van den Beld, I.M.J., Guillaumont, B., Menot, L., Bayle, C., Arnaud-Haond, S., Bourillet, J.-F., 2016. Marine litter in submarine canyons of the Bay of Biscay. Deep Sea Research Part II: Topical Studies in Oceanography. https://doi.org/10.1016/j.dsr2.2016.04.013

van Nes, E.H., Arani, B.M.S., Staal, A., van der Bolt, B., Flores, B.M., Bathiany, S., Scheffer, M., 2016. What Do You Mean, "Tipping Point"? Trends in Ecology \& Evolution 31, 902-904. https://doi.org/10.1016/j.tree.2016.09.011 
Vardaro, M.F., Parmley, D., Smith, K.L., 2007. A study of possible "reef effects" caused by a long-term time-lapse camera in the deep North Pacific. Deep Sea Research Part I: Oceanographic Research Papers 54, 1231-1240. https://doi.org/10.1016/j.dsr.2007.05.004

Venables, W.N., Ripley, B.D., 2002. Random and Mixed Effects, in: Venables, W.N., Ripley, B.D. (Eds.), Modern Applied Statistics with S. Springer New York, New York, NY, pp. 271-300.

Vetter, E., Dayton, P., 1999. Organic enrichment by macrophyte detritus, and abundance patterns of megafaunal populations in submarine canyons. Marine Ecology Progress Series 186, 137148. https://doi.org/10.3354/meps186137

Vetter, E.W., 1994. Hotspots of benthic production. Nature 372, 47-47. https://doi.org/10.1038/372047a0

Vetter, E.W., Smith, C.R., De Leo, F.C., 2010. Hawaiian hotspots: enhanced megafaunal abundance and diversity in submarine canyons on the oceanic islands of Hawaii: Megafaunal diversity and abundance in oceanic submarine canyons. Marine Ecology 31, 183-199. https://doi.org/10.1111/j.1439-0485.2009.00351.x

Vosloo, A., Laas, A., Vosloo, D., 2013. Differential responses of juvenile and adult South African abalone (Haliotis midae Linnaeus) to low and high oxygen levels. Comparative Biochemistry and Physiology Part A: Molecular \& Integrative Physiology 164, 192-199. https://doi.org/10.1016/j.cbpa.2012.09.002

Wagner, H.-J., Kemp, K., Mattheus, U., Priede, I.G., 2007. Rhythms at the bottom of the deep sea: Cyclic current flow changes and melatonin patterns in two species of demersal fish. Deep Sea Research Part I: Oceanographic Research Papers 54, 1944-1956. https://doi.org/10.1016/j.dsr.2007.08.005

Watanabe, T., 2002. Method to Estimate the Population Density of the Snow Crab Chionoecetes opilio Using a Deep-Sea Video Monitoring System on a Towed Sledge. Japan Agricultural Research Quarterly: JARQ 36, 51-57. https://doi.org/10.6090/jarq.36.51 
Whitney, F.A., Freeland, H.J., Robert, M., 2007. Persistently declining oxygen levels in the interior waters of the eastern subarctic Pacific. Progress in Oceanography 75, 179-199. https://doi.org/10.1016/j.pocean.2007.08.007

Whittaker, T., Robinson, M.., 1923. The calculus of observations, a treatise on numerical mathematics. Quarterly Journal of the Royal Meteorological Society 50, 163-164. https://doi.org/10.1002/qj.49705021024

Widder, E.A., Robison, B.H., Reisenbichler, K.R., Haddock, S.H.D., 2005. Using red light for in situ observations of deep-sea fishes. Deep Sea Research Part I: Oceanographic Research Papers 52, 2077-2085. https://doi.org/10.1016/j.dsr.2005.06.007

Workman, G.D., Philips, A.C., Scurrah, F.E., Boutillier, J.A., 2002. A new fishery for grooved Tanner crab (Chionoecetes tanneri) off the coast of British Columbia, Canada. Alaska Sea Grant, University of Alaska Fairbanks, pp. 439-456. https://doi.org/10.4027/ccwrbme.2002.33

Zùñiga, D., Flexas, M.M., Sanchez-Vidal, A., Coenjaerts, J., Calafat, A., Jordà, G., Garcia-Orellana, J., Puigdefàbregas, J., Canals, M., Espino, M., Sardà, F., Company, J.B., 2009. Particle fluxes dynamics in Blanes submarine canyon (Northwestern Mediterranean). Progress in Oceanography 82, 239-251. https://doi.org/10.1016/j.pocean.2009.07.002 


\section{ACKNOWLEDGMENTS:}

We are grateful to al PIs of ONC for accessing their temporal data. Funding for the Barkley Canyon instruments and installation was provided by the Canada Foundation for Innovation and the British Columbia Knowledge Development Fund. This research was supported by the "Laboratoire d'Excellence" LabexMER (ANR-10-LABX-19) and co-funded by a grant from the IFREMER and the region of Brittany. Authors are also very thankful to A. Warén, F. Gervais and G. Jensen who helped to identify taxa. K. Douglas provided the bathymetry data used by R. Autret to build the map of Barkley Canyon. We also thank F. De Leo and an anonymous reviewer for their comments on an earlier version of the paper that significantly helped improving the manuscript.

\section{COMPETING INTERESTS}

No competing interests to declare

CONFLICTS OF INTEREST

None

\section{AUTHOR'S CONTRIBUTION}

P.C., M.M. and A.M. conceived the ideas and contributed to the interpretation of the results. P.C. collected and analyzed data. A.H. analyzed and interpreted current and wind data. A.M. and M.M. supervised the research project. All authors assisted in the writing process and revised the manuscript. 


\section{LIST OF FIGURES}

Figure 1: Location map.

$\rightarrow$ Single column fitting image

Figure 2: Time series of weather and sea-surface parameters

$\rightarrow 2$ columns

Figure 3: Time series of in-situ measurements

$\rightarrow 2$ columns

Figure 4: Images of the major species

$\rightarrow 1$ column

Figure 5: Time series of density (ind $/ \mathrm{m}^{2}$ ) of major species

$\rightarrow 2$ columns

Figure 6: Cumulative frequency of species density

$\rightarrow 1$ column

Figure 7: PCA performed on megafaunal density

$\rightarrow 1$ column

Figure 8: Scalogram

$\rightarrow 1.5$ columns

Appendix 1 Map of the surface used to obtain one single value of chlorophyll concentration

$\rightarrow 1$ column

Appendix 2 Results of the MRT analysis

$\rightarrow 2$ columns 
Appendix 4, Figure 1: Whittaker-Robinson periodogram statistics computed for sea surface concentration in chlorophyll

$\rightarrow 2$ columns

Appendix 4, Figure 2: Whittaker-Robinson periodogram statistics computed for sea surface and weather parameters

$\rightarrow 2$ columns

Appendix 4, Figure 3: Robinson periodogram statistics computed for in situ bottom parameter

$\rightarrow 2$ columns

Appendix 4, Figure 4: Whittaker-Robinson periodogram statistics computed for motility categories

$\rightarrow 2$ columns

Appendix 4, Figure 5: Whittaker-Robinson periodogram statistics computed for major species densities

$\rightarrow 2$ columns

\section{LIST OF TABLES}

Table 1: List of instruments measuring hydrographic parameters

Table 2: Characteristics of cameras installed at each maintenance cruise

Table 3: Environmental parameters from 17 June 2012 to 6 January 2015

Table 4: List of benthic megafauna recorded from the axis of Barkley Canyon

Table 5: Results of the correlations performed on the densities of all OTUs aggregated by month and motility

Table 6: $\mathrm{R}^{2}$ and probabilities related to the temporal analysis of the epibenthic megafaunal community 
Table 7: Results of the correlations performed between daily anomaly of sea surface temperature 


\section{APPENDICES}

Appendix 1: Map of surface chlorophyll

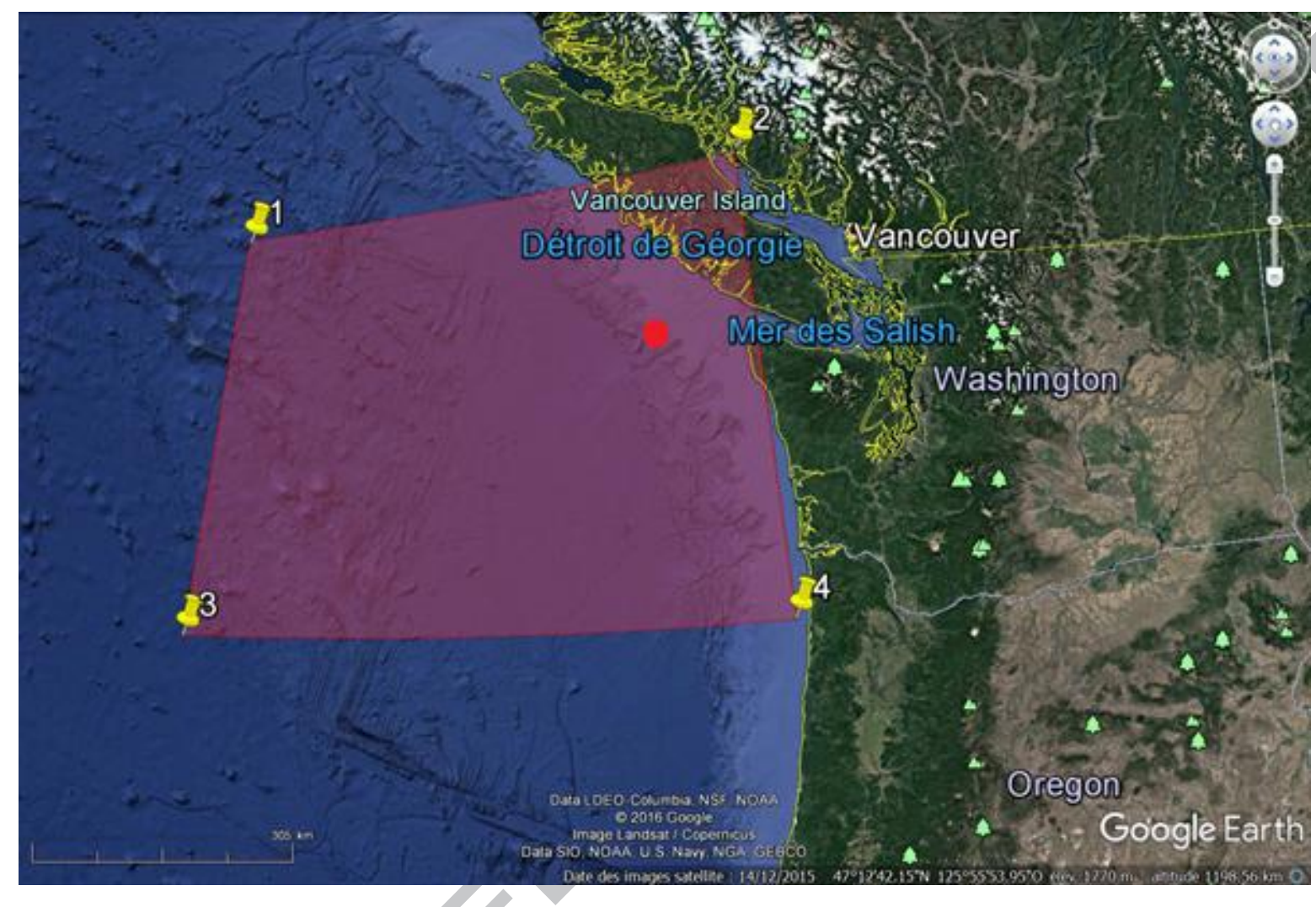

Appendix 3 Map of the surface used to obtain one single value of chlorophyll concentration for the analysis. Chlorophyll (chl) data are a spatial averaged of the square surface around Barkley Canyon (red square surface = $\left.144 \mathrm{~km}^{2}\right)$. Coordinates of point $1=49^{\circ} 5^{\prime} 21.50^{\prime \prime} \mathrm{N} ; 132^{\circ} 4^{\prime} 5.62^{\prime \prime} \mathrm{O}$, point $2=50^{\circ} 3^{\prime} 9.32^{\prime \prime} \mathrm{N} ; 124^{\circ} 52^{\prime} 6.47^{\prime \prime} \mathrm{O}$, point 3 $=45^{\circ} 13^{\prime} 34.96^{\prime \prime} \mathrm{N} ; 132^{\circ} 36^{\prime} 51.32^{\prime \prime} \mathrm{O}$, point $4=45^{\circ} 34^{\prime} 6.82^{\prime \prime} \mathrm{N} ; 124^{\circ} 7^{\prime} 52.19^{\prime \prime} \mathrm{O}$. The chlorophyll concentration is obtained from the 8-day averages given by the MODIS model which uses NASA satellites (neo.sci.gsfc.nasa.gov). 
Appendix 2: MRT analysis

MRT on megafauna density data

Explanatory variable $=$ days

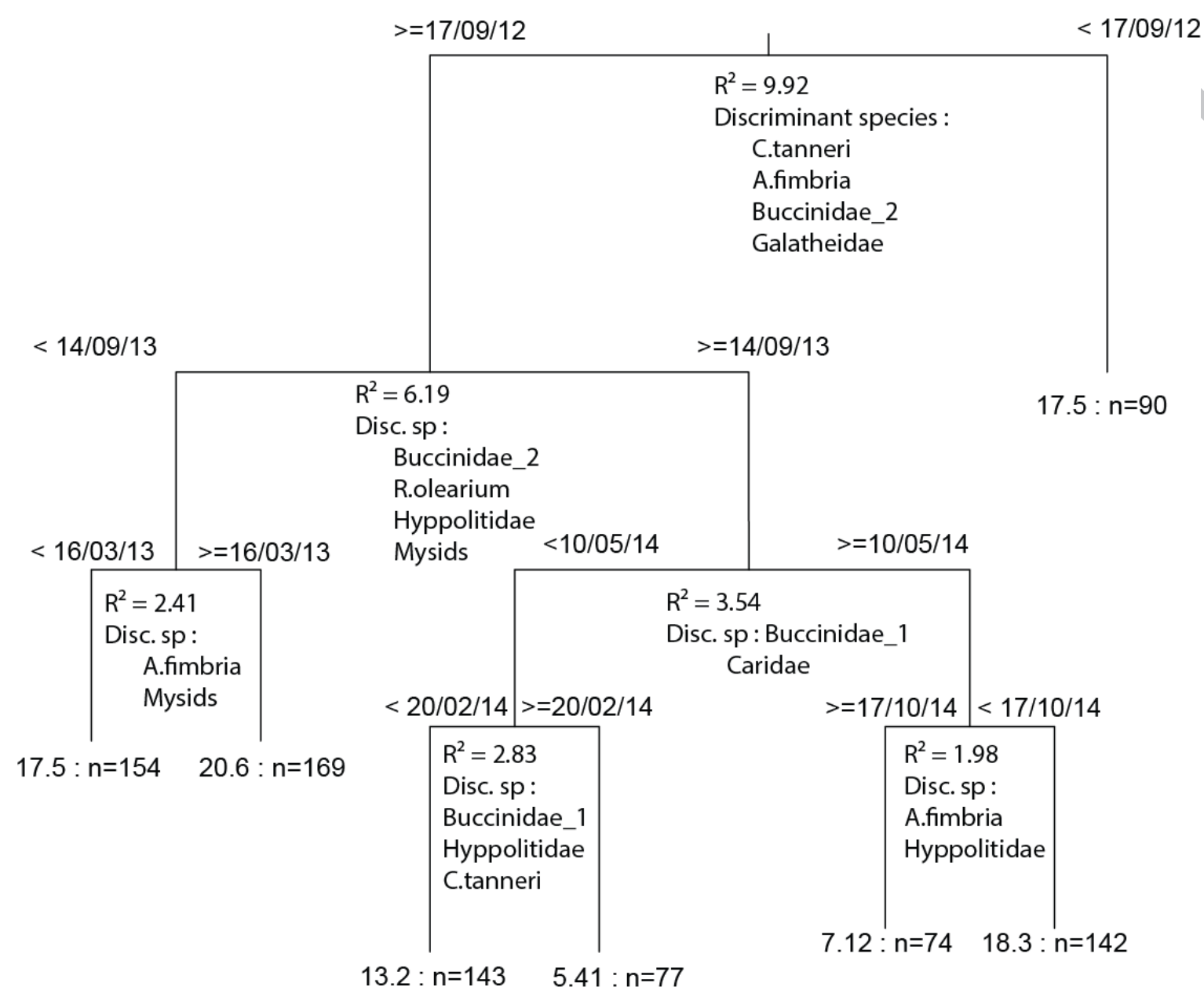

Error : 0.731 CV Error : 0.755 SE : 0.0198

Appendix 4 Results of the MRT analysis performed on megabenthic community sampled from 17 June 2012 to 6 January 2015 in at 985 m depth from 08 h 00 to 08 h 05 with a stationary video camera at the axis of Barkley Canyon (British Columbia, Canada). For each node the $\mathrm{R}^{2}$ (contribution of each node to the explained variance) and discriminant species are shown.

The following paragraph is the method describing Multivariate Regression Tree analysis we used to verify a potential impact of the maintenance cruise on the temporal patterns observed in the community composition:

MRT result is a tree whose terminal groups of sites are a subset of sites chosen to minimize the within-cluster sums of squares and where each successive partition is defined by the dates (Borcard 
et al., 2011). The contribution of each node to the explained variance is called complexity (the sum of those complexity gives the overall $R^{2}$ ). The "discriminant" species at each node are identified by selection of the species contributing the most to the variance down to a minimum of 10 . 


\section{Appendix 3: DbMEM method}

The following paragraph is the method describing DbMEM analysis used to identify temporal structure in the community composition and the role of environmental factors driving these patterns:

The steps involved in the generation of dbMEM are (Rádková et al., 2014):

1. Starting from the dates of the sampling period ( 1 sample per day from June 2012 to January 2015: $\mathrm{n}=847$ ), a Hellinger distance matrix $\mathrm{D}$ was calculated for all possible distances dij between sampling dates $i$ and $j$.

2. A temporal connectivity function $\mathrm{W}$ was constructed by truncating $\mathrm{D}$ at a distance $\mathrm{dt}$ (Borcard and Legendre, 2002; Dray et al., 2006; Griffith and Peres-Neto, 2006), which is either equal to or larger than the length of the longest link in the minimum spanning tree on $D$ (this length represents the shortest distance required to maintain the network of all dates connected) (Borcard et al., 2004). In essence, $\mathrm{W}$ is a truncated matrix in which only some dates are connected. Each non-null weight wij indicates the possible connection between dates $\mathrm{i}$ and $\mathrm{j}$, and the actual value of wij illustrates the strength of the potential interaction between the two temporal units $i$ and $j$ (Dray et al., 2006).

3. A principal coordinate analyses applied to the truncated Euclidean distance matrix W generated the eigenvectors (dbMEMs). The procedure yields both positive and negative eigenvalues. DbMEMs paired with positive eigenvalues depict a positive temporal association, whereas dbMEMs paired with negative eigenvalues depict a negative temporal association (Griffith and Peres-Neto, 2006).

4. Significance of the dbMEMs was tested with a forward selection. The significant positive and negative dbMEMs were used as explanatory variables in Redundancy analysis (RDA) to estimate the percentage of variations in community composition explained by temporal structure.

For our analyses, we only focused on positive temporal association (i.e.,+dbMEM). A scalogram of the relative importance of the +dbMEM eigenfunctions was plotted. The contributions of the 
eigenfunctions to modelling the variation of the community series are given by the semipartial $R^{2}$ of each MEM, but the significance is the one found during forward selection of the eigenfunctions. 
Appendix 4: Periodogram figures

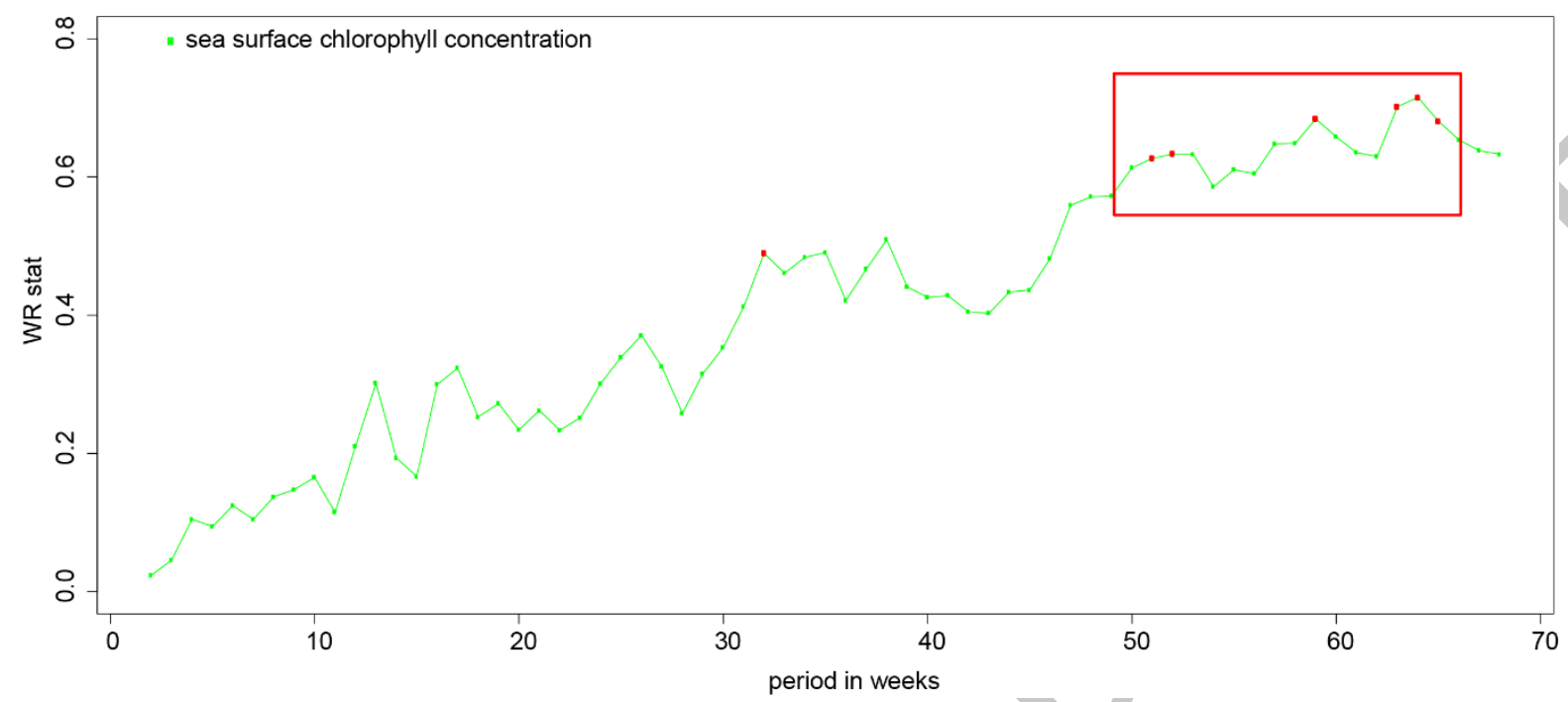

Appendix 4, Figure 1: Whittaker-Robinson periodogram statistics computed for sea surface concentration in chlorophyll, featuring periods comprised between 2 and 68 weeks. Red squares indicate periods that are significant at the $5 \%$ level. Chlorophyll (chl) data values are a spatial averaged of a square surface around Barkley Canyon (British Columbia, Canada; $45^{\circ} 56^{\prime}$ to $50^{\circ} 05^{\prime} \mathrm{N}, 124^{\circ} 87^{\prime}$ to $132^{\circ} 07^{\prime} \mathrm{W}$ ) obtained from the 8-day averages given by the MODIS model (neo.sci.gsfc.nasa.gov).

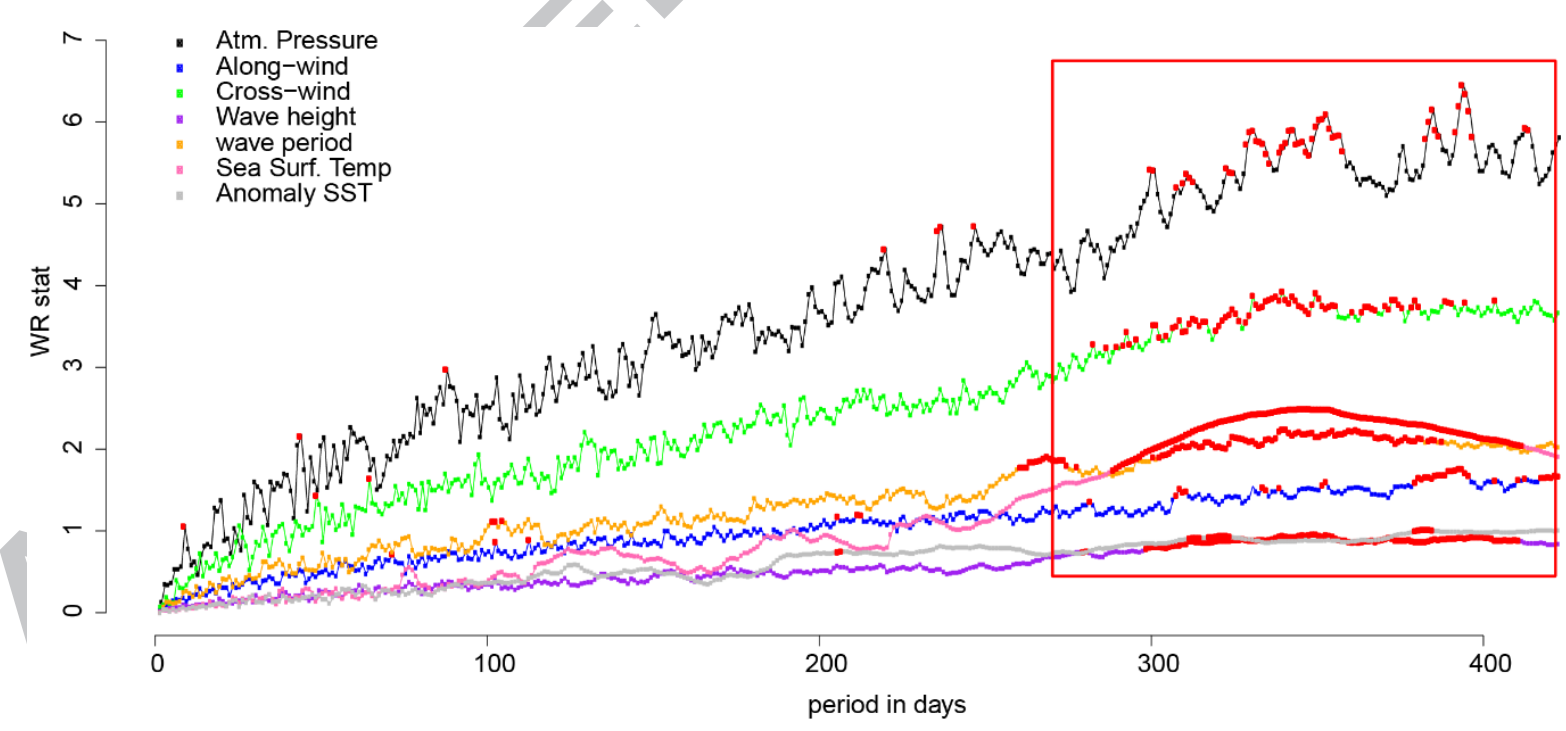

Appendix 4, Figure 2: Whittaker-Robinson periodogram statistics computed for sea surface and weather parameters, featuring periods comprised between 2 and 423 days. Red squares indicate periods that are significant at the $5 \%$ level. Wave height, wind speed, atmospheric pressure, sea surface temperature, anomaly of sea surface temperature (Anomaly SST) parameters are given or derived from hourly data recorded by LaPerouse buoy (Tofino, British Columbia, Canada). 


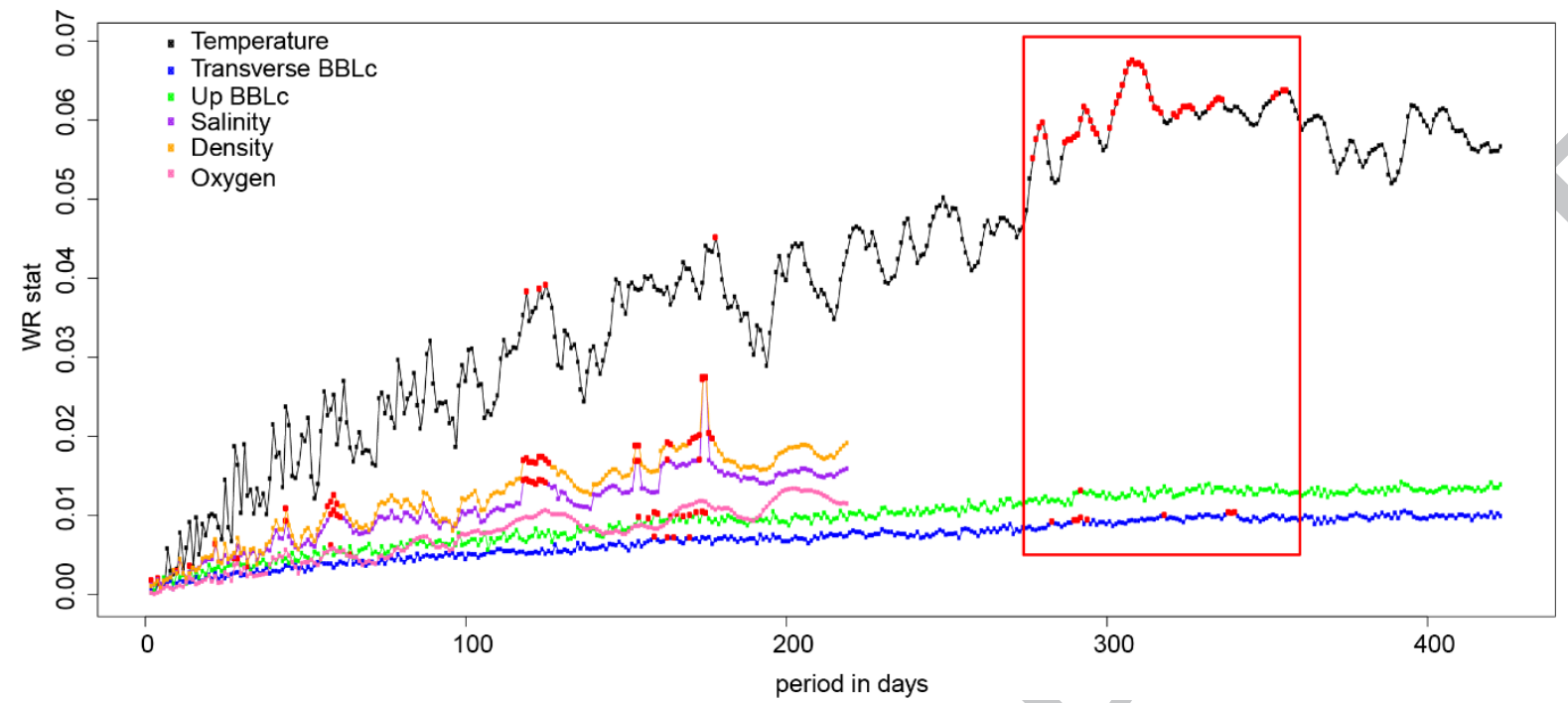

Appendix 4, Figure 3: Robinson periodogram statistics computed for in situ bottom parameter , featuring periods comprised between 2 and 423 days for Temperature and Benthic Boundary Layer currents (BBLC) and between 2 and 219 days for Salinity, Density and Oxygen. Red squares indicate periods that are significant at the $5 \%$ level. In situ BBLc, transverse component and up-canyon component and temperature (from June 2012 to January 2015), and oxygen, salinity and density (from September 2013 to January 2015) were measured at POD1 Ocean Networks Canada observatory site (British Columbia, Canada) using an ADCP for BBLC and temperature, and an oxygen optode and a CTD for the salinity and density

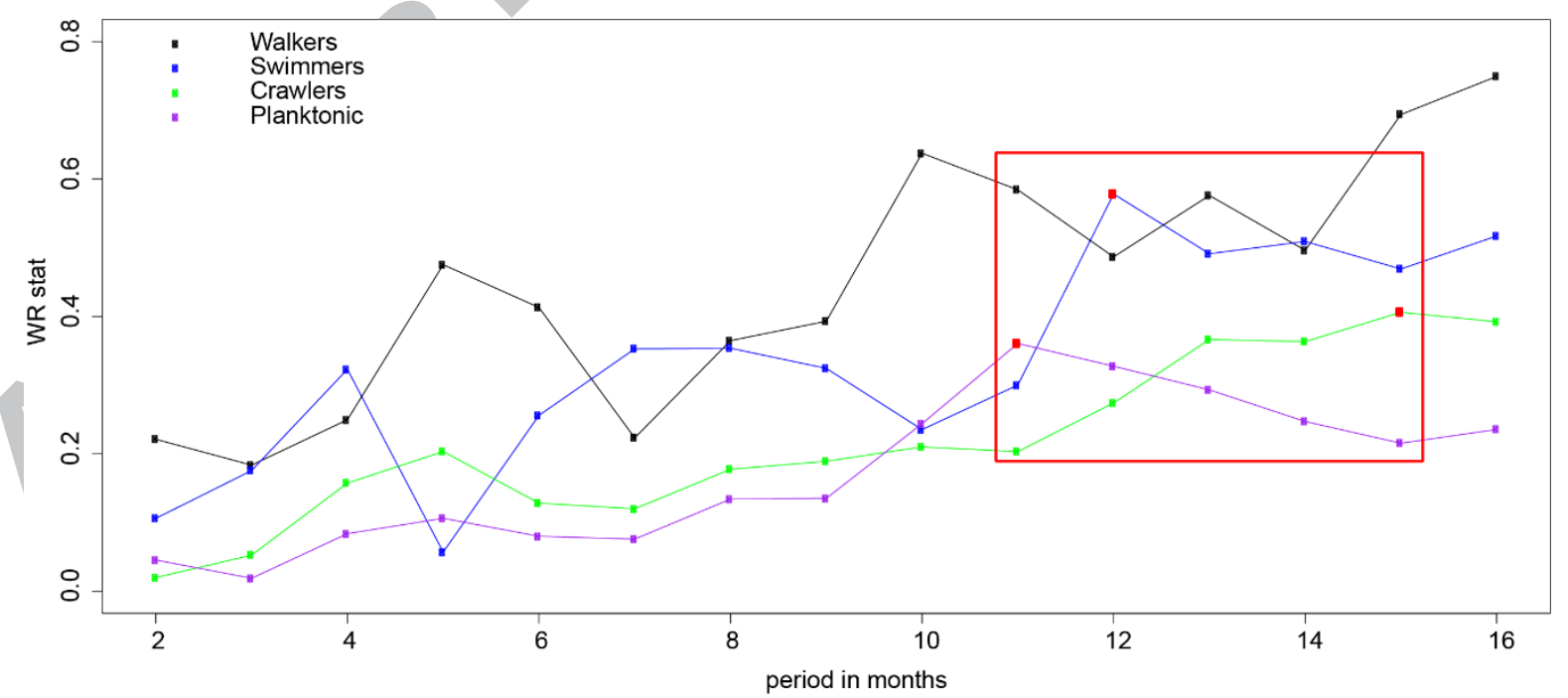

Appendix 4, Figure 4: Whittaker-Robinson periodogram statistics computed for motility categories featuring periods comprised between 2 and 16 months. Species density were aggregated by their motility type and by month, sampled once per day with stationary video camera from $08 \mathrm{~h} 00$ to $08 \mathrm{~h} 05$ at $985 \mathrm{~m}$ depth at the axis of Barkley Canyon (British Columbia, Canada) from 17 June 2012 to 6 January 2015. Red squares indicate 
periods that are significant at the $5 \%$ level.

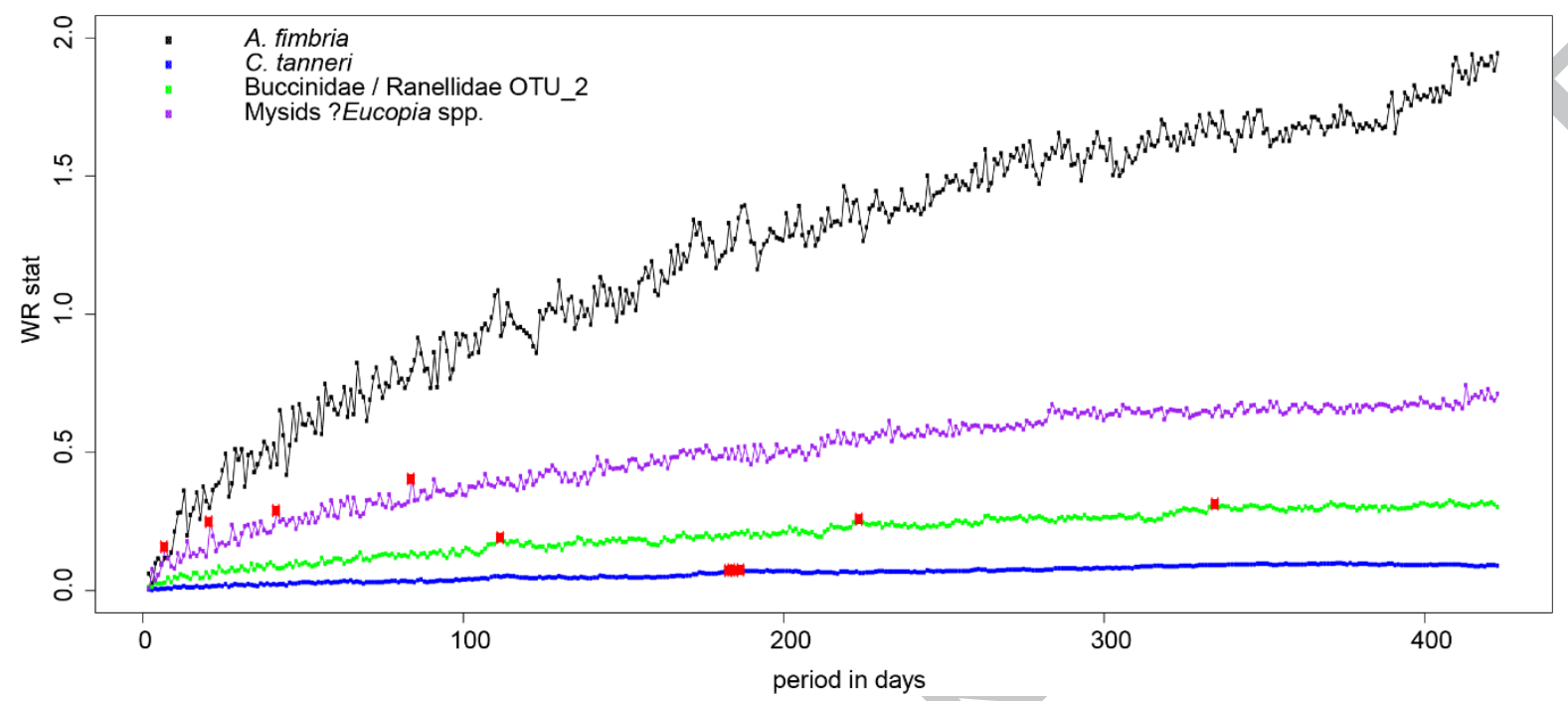

Appendix 4, Figure 5: Whittaker-Robinson periodogram statistics computed for major species densities, featuring periods comprised between 2 and 423 days. Red squares indicate periods that are significant at the $5 \%$ level. Densities were obtained from fauna sampled once per day with stationary video camera from $08 \mathrm{~h}$ 00 to $08 \mathrm{~h} 05$ at 985 m depth at the axis of Barkley Canyon (British Columbia, Canada) from 17 June 2012 to 11 January 2015. 


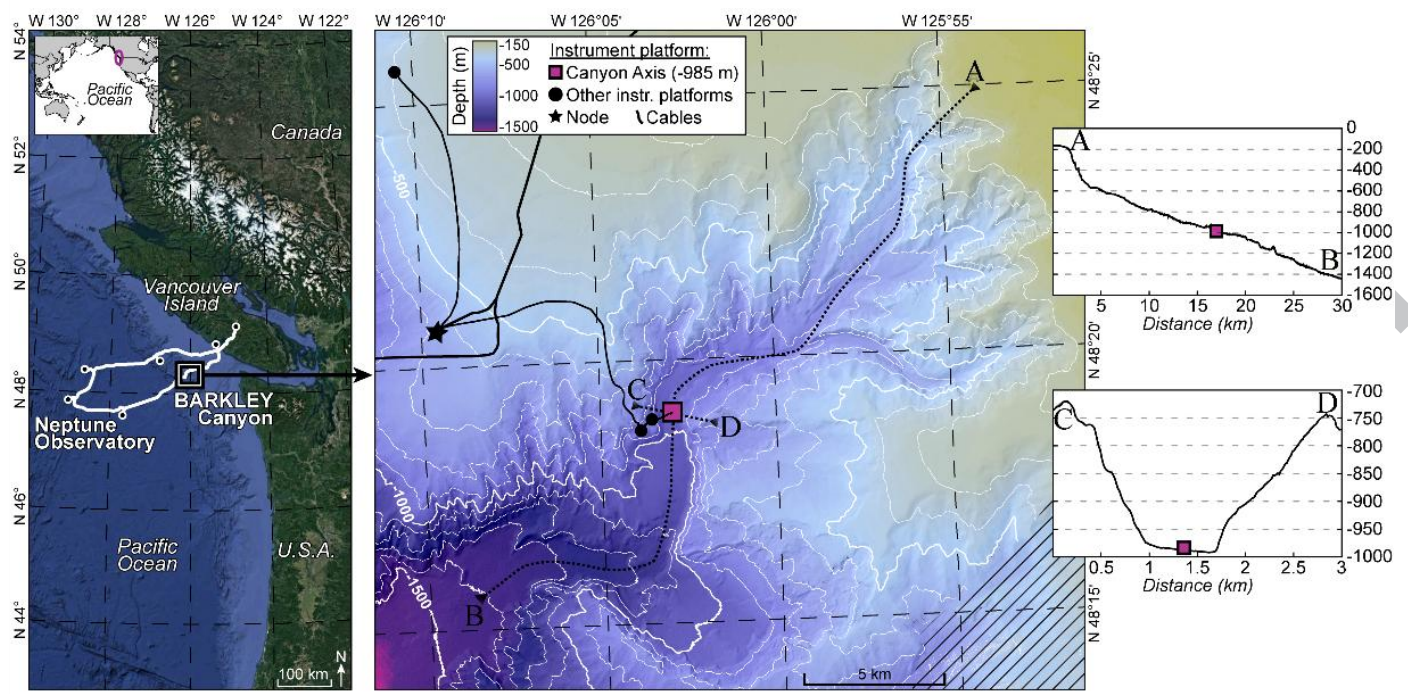

Figure 1: Location map. Left panel: position of the observatory network Ocean Networks Canada offshore Vancouver Island (BC, Canada). Right panel: bathymetric map of Barkley Canyon showing ONC platforms; the axis (POD1 platform) sampling site, at $985 \mathrm{~m}$ depth, is shown as the pink square. Inset side: topography of transects crossing the canyon in length (A-B) and width (C-D). 


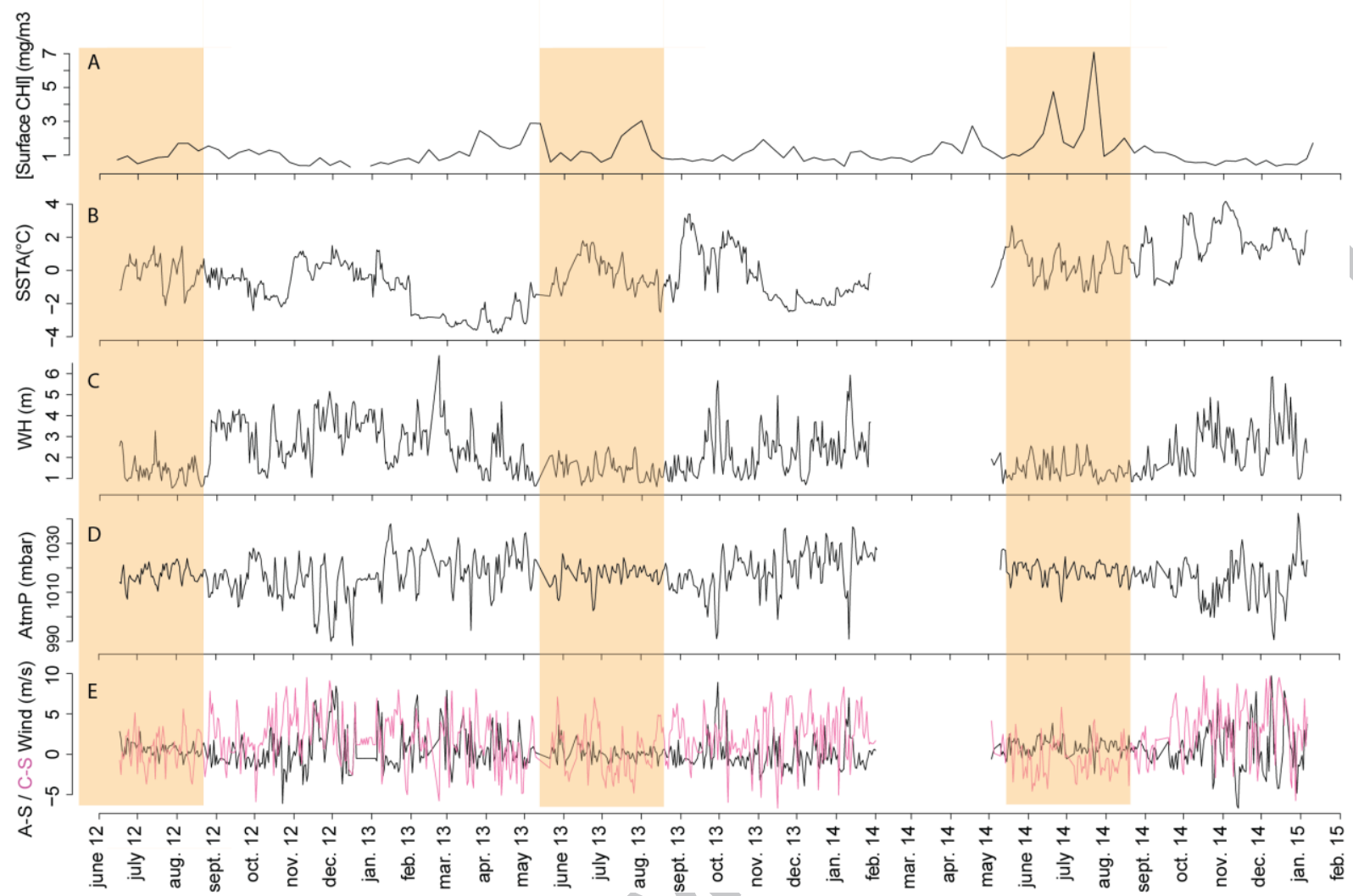

Figure 2: Time series of A- surface chlorophyll concentration (8-day averaged of a single value representing a sampling in a square surface around Barkley Canyon $\left(45^{\circ} 56^{\prime}\right.$ to $50^{\circ} 05^{\prime} \mathrm{N}, 124^{\circ} 87^{\prime}$ to $132^{\circ} 07^{\prime} W$ ) obtained with the MODIS model using NASA satellites, B-Daily anomaly of sea surface temperature obtained from sea surface temperature recorded from 1988 to 2015 by La Perouse buoy (Tofino, British Columbia, Canada), ) C-wave height (daily averaged) and D-atmospheric pressure (daily averaged) measured by LaPerouse buoy (Tofino, British Columbia, Canada) ,E-along-slope (black line) and cross-slope (red line) wind (daily vectored averaged). Yellow shading highlights summer time. Blue lines represent the 3 years averages. Sampling dates are from 17 June 2012 to 6 January 2015. 


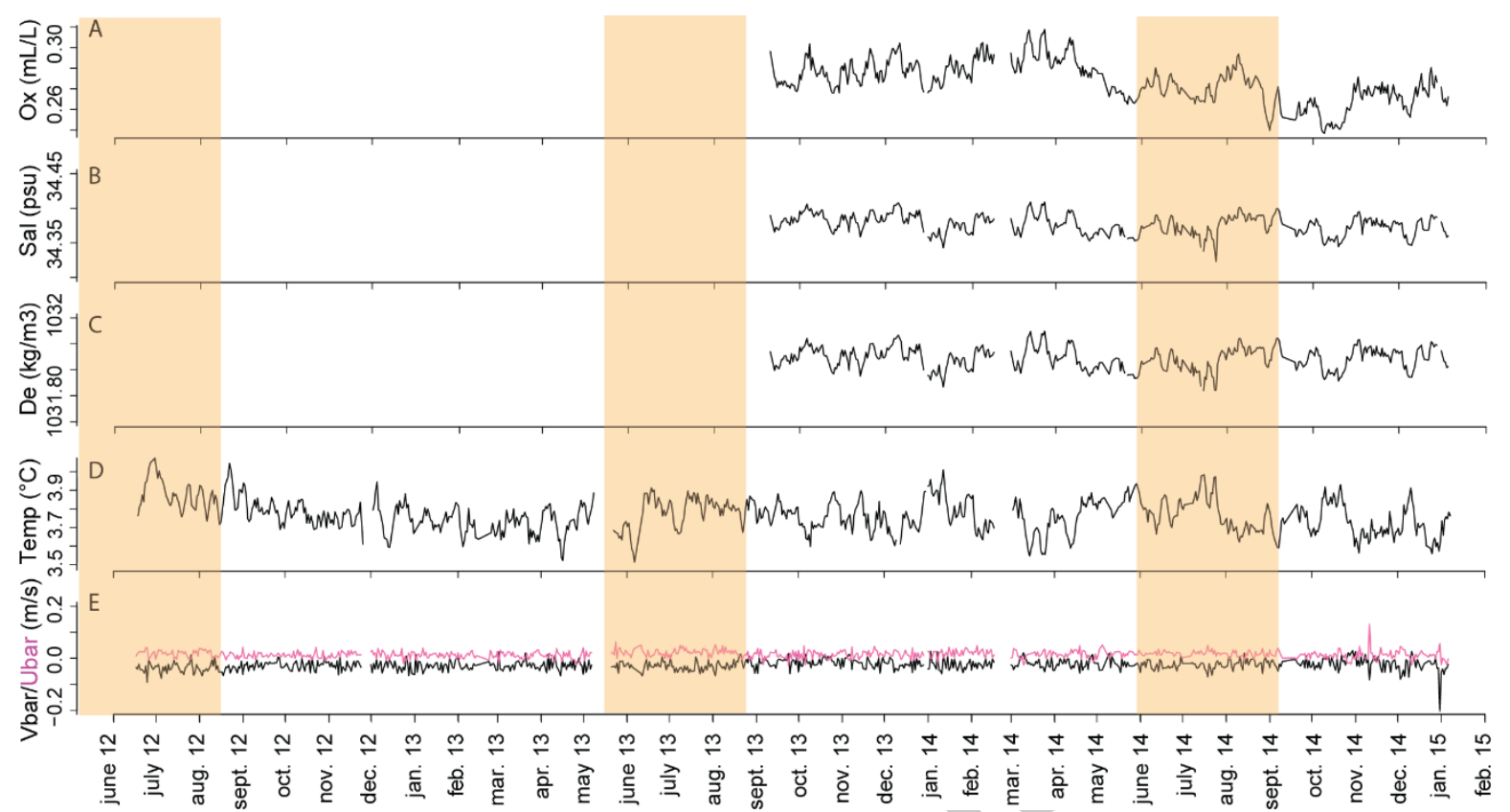

Figure 3: Time series of in-situ measurements made at POD1 ONC observatory site at the axis of Barkley Canyon (British Columbia, Canada) at 985 m depth using an optode (oxygen), a CTD (salinity and density) and an ADCP (BBLc and temperature). A-Oxygen concentration ( $\mathrm{ml} / \mathrm{L})$, B-Salinity (psu) C- Density $\left(\mathrm{kg} / \mathrm{m}^{3}\right), D$ - Temperature $\left({ }^{\circ} \mathrm{C}\right), \mathrm{E}$ - Up-canyon (black) and transverse-canyon Benthic Boundary Layer currents $(\mathrm{m} / \mathrm{s})$. Yellow shading highlights summer time. Sampling dates are from 17 June 2012 to 6 January 2015. 


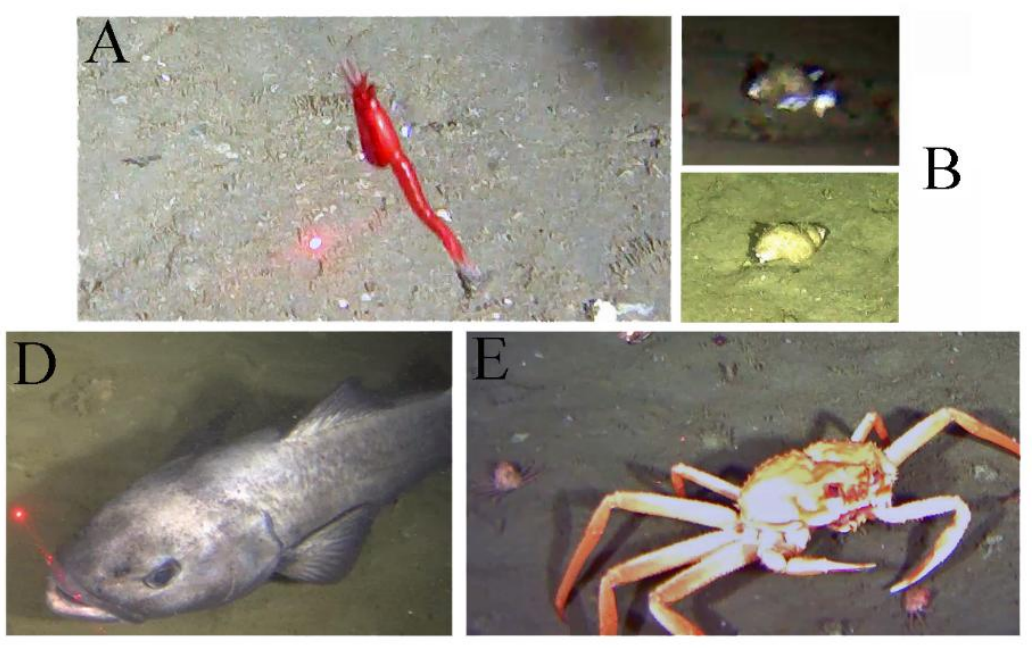

Figure 4: Images of the major species observed with a stationary video camera at the axis of Barkley Canyon (British Columbia, Canada) at 985 m depth from 17 June 2012 to 6 of January 2015. A Mysids, likely Eucopia spp; B Buccinidae_OTU_2; C Buccinidae_OTU_1; D Anoplopoma fimbria and; E Chionoecetes tanneri. 


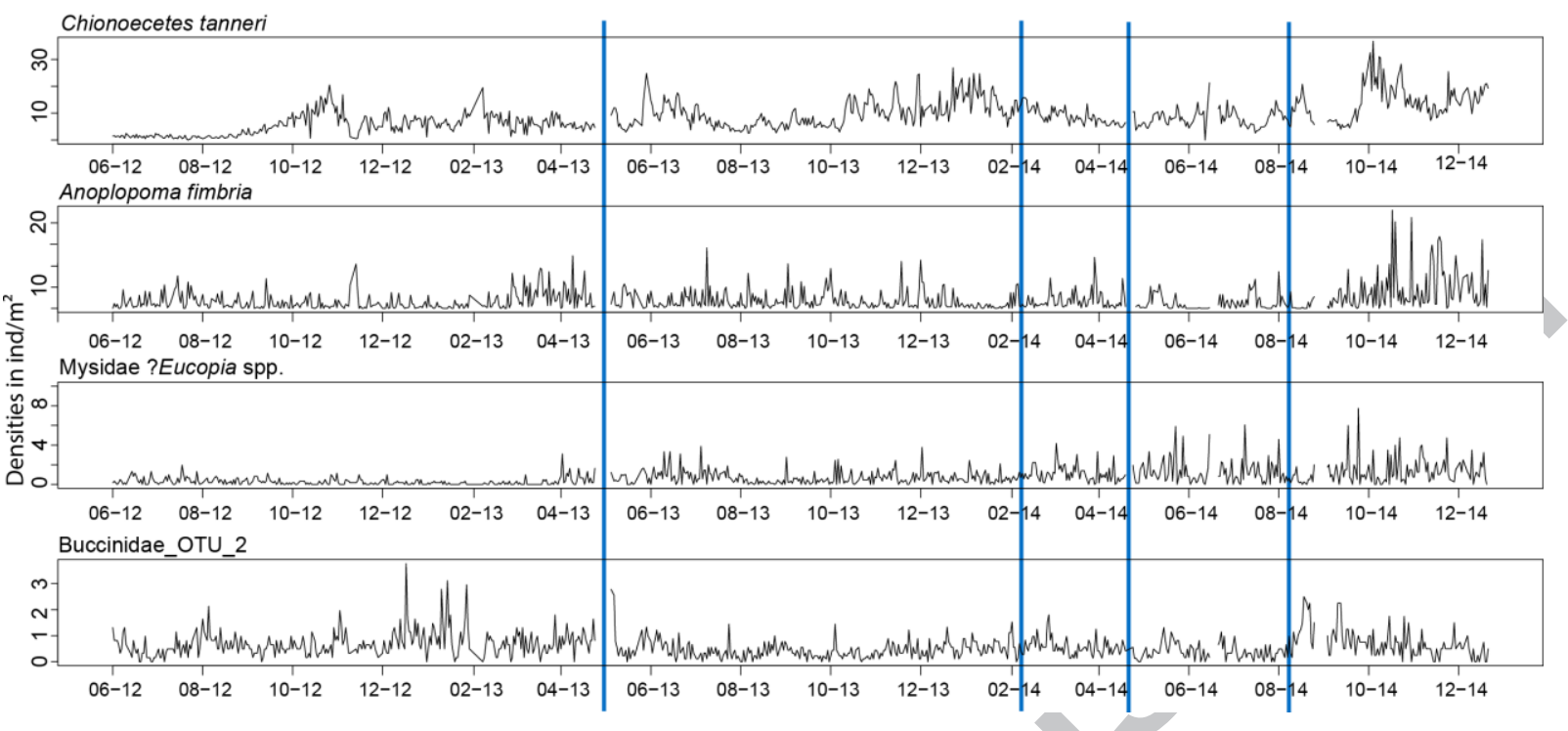

Figure 5: Time series of density $\left(\mathrm{ind} / \mathrm{m}^{2}\right.$ ) of major species recorded with a stationary video camera at the axis of Barkley Canyon (British Columbia, Canada) at $985 \mathrm{~m}$ depth from June 2012 to January 2015. The mysids were probably ?Eucopia spp. Blue vertical lines indicate a change in camera parameters which modified the field of view and/or the area coverage. 


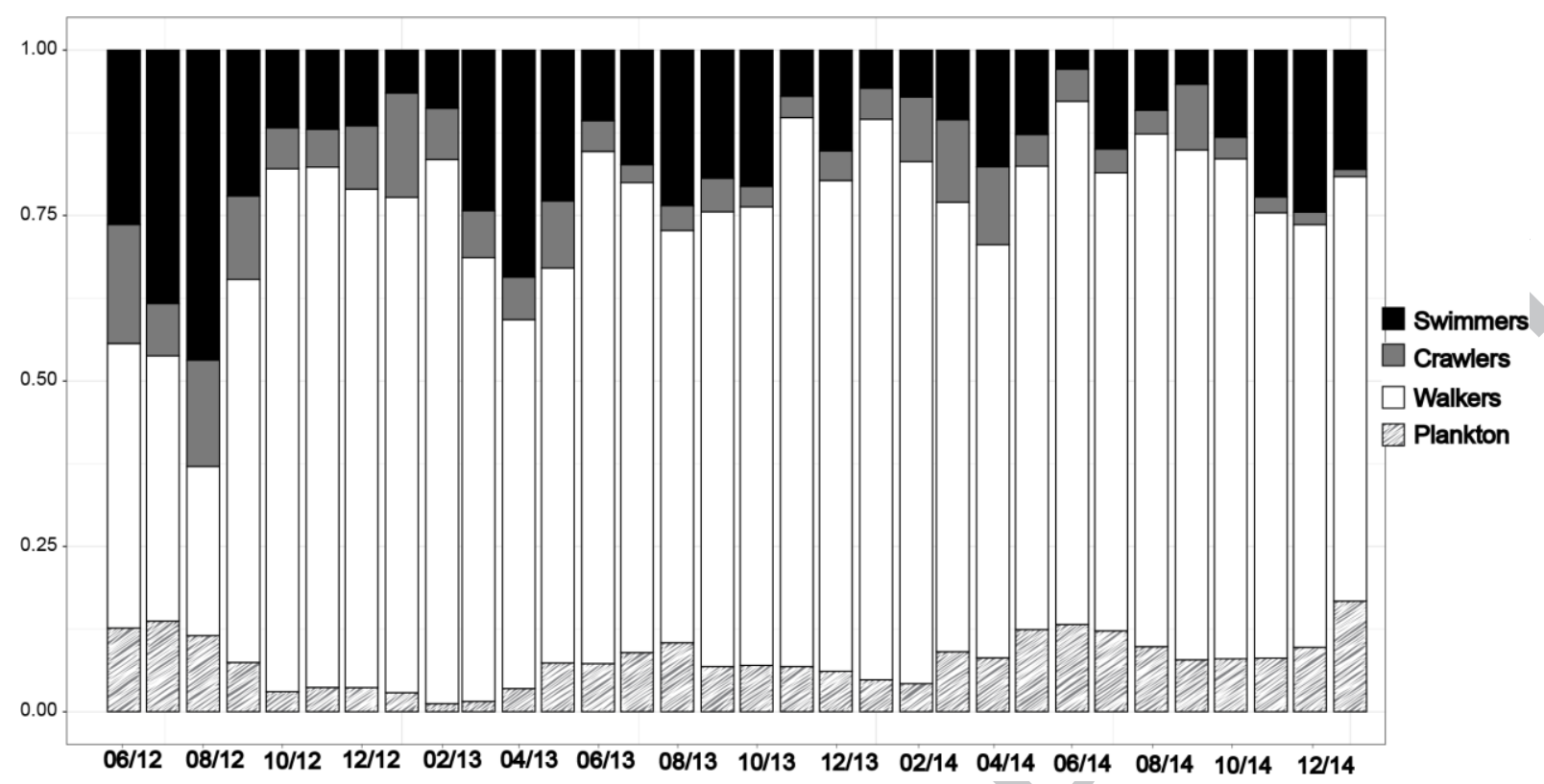

Figure 6: Cumulative frequency of species density aggregated by their motility type and by month, sampled once per day with stationary video camera from $08 \mathrm{~h} 00$ to $08 \mathrm{~h} 05$ at $985 \mathrm{~m}$ depth at the axis of Barkley Canyon from 17 June 2012 to 6 January 2015. 


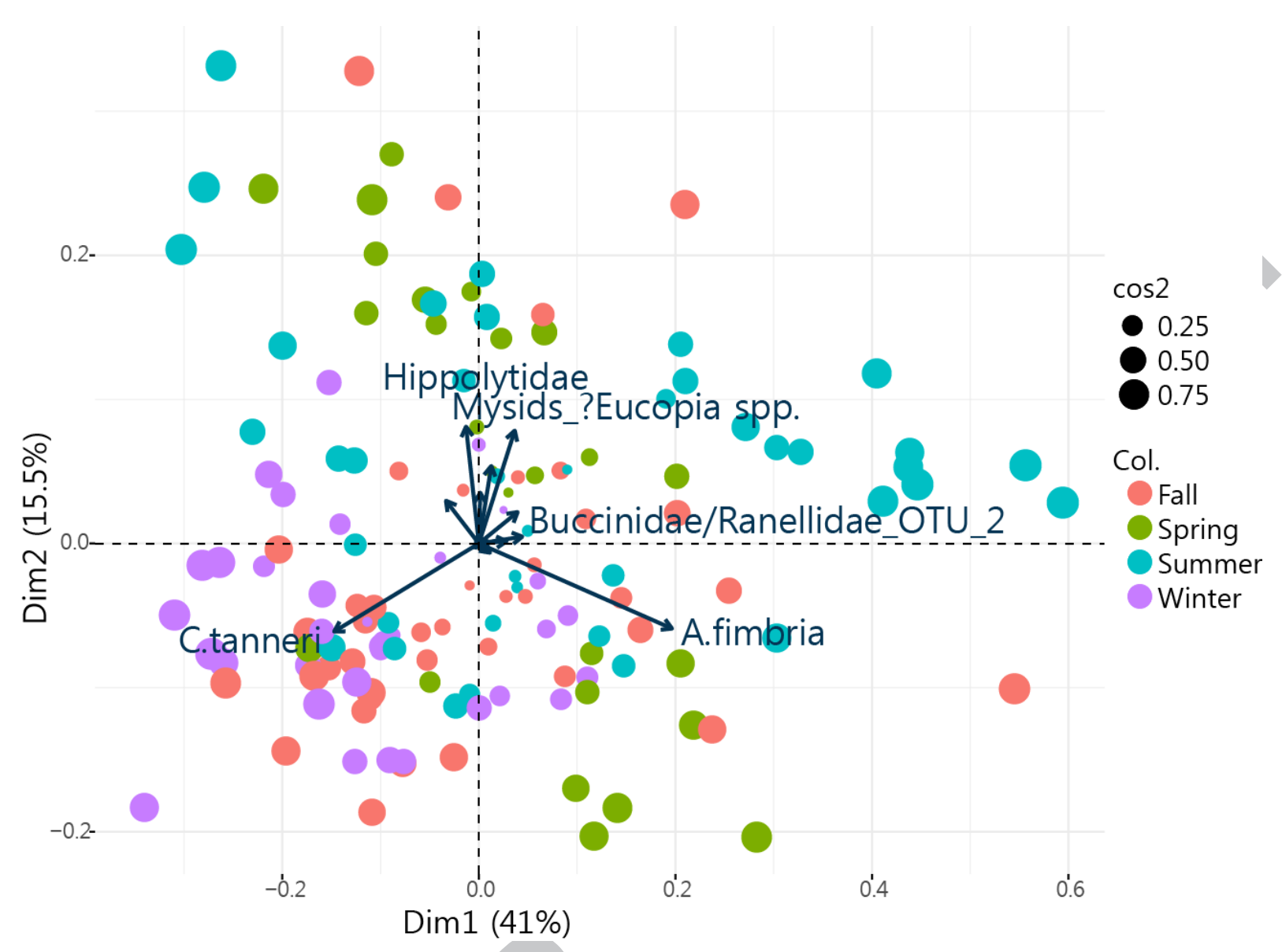

Figure 7: PCA performed on megafaunal density recorded with a stationary video camera from $08 \mathrm{~h}$ 00 to 08 h 05 every day from 17 June 2012 to 6 January 2015 at 985 m depth at the axis of Barkley Canyon (British Columbia, Canada). Daily values were aggregated by week (sum) then transformed according to Hellinger. The arrows represent species that contributed to the observed variance. Species near the origin of the axes were removed to improve clarity. The size of the points is a function of $\cos 2$, indicating the quality of its representation on the chosen dimensions. 


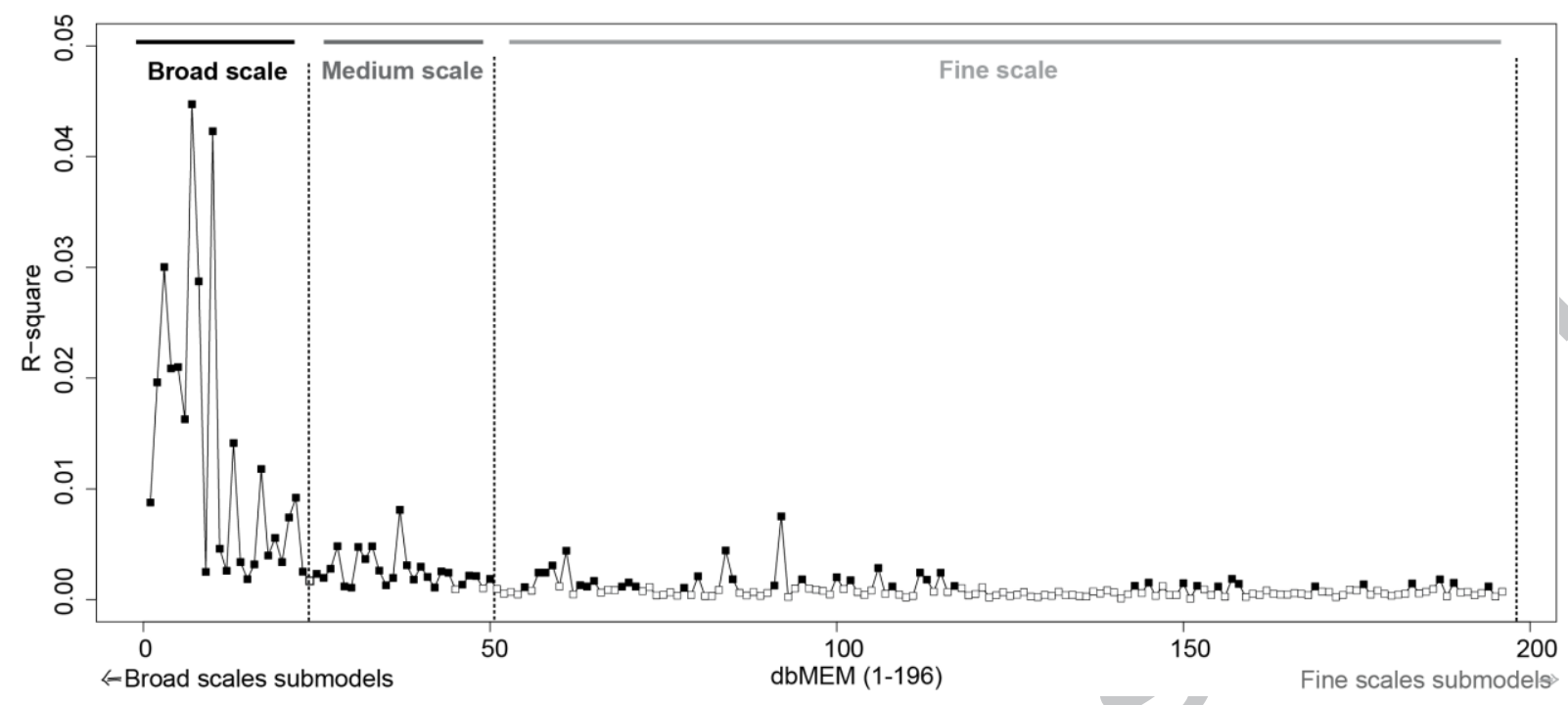

Figure 8: Scalogram illustrating the scaling of temporally structured variation in benthic megafauna community data at the axis of Barkley Canyon (British Columbia, Canada) sampled with a stationary video camera at $985 \mathrm{~m}$ depth every day from 08h00 to 08h05 from 17 June 2012 to 6 January 2015. Values on the ordinate are semi-partial $R^{2}$ (i.e., the variation explained by individual dbMEM variables), computed separately for each dbMEM eigenfunction with positive Moran's I (1-196). The statistics of the dbMEM that were selected by forward selection (i.e. the 78 that significantly contributed to model the faunal response data) are represented by black squares. 


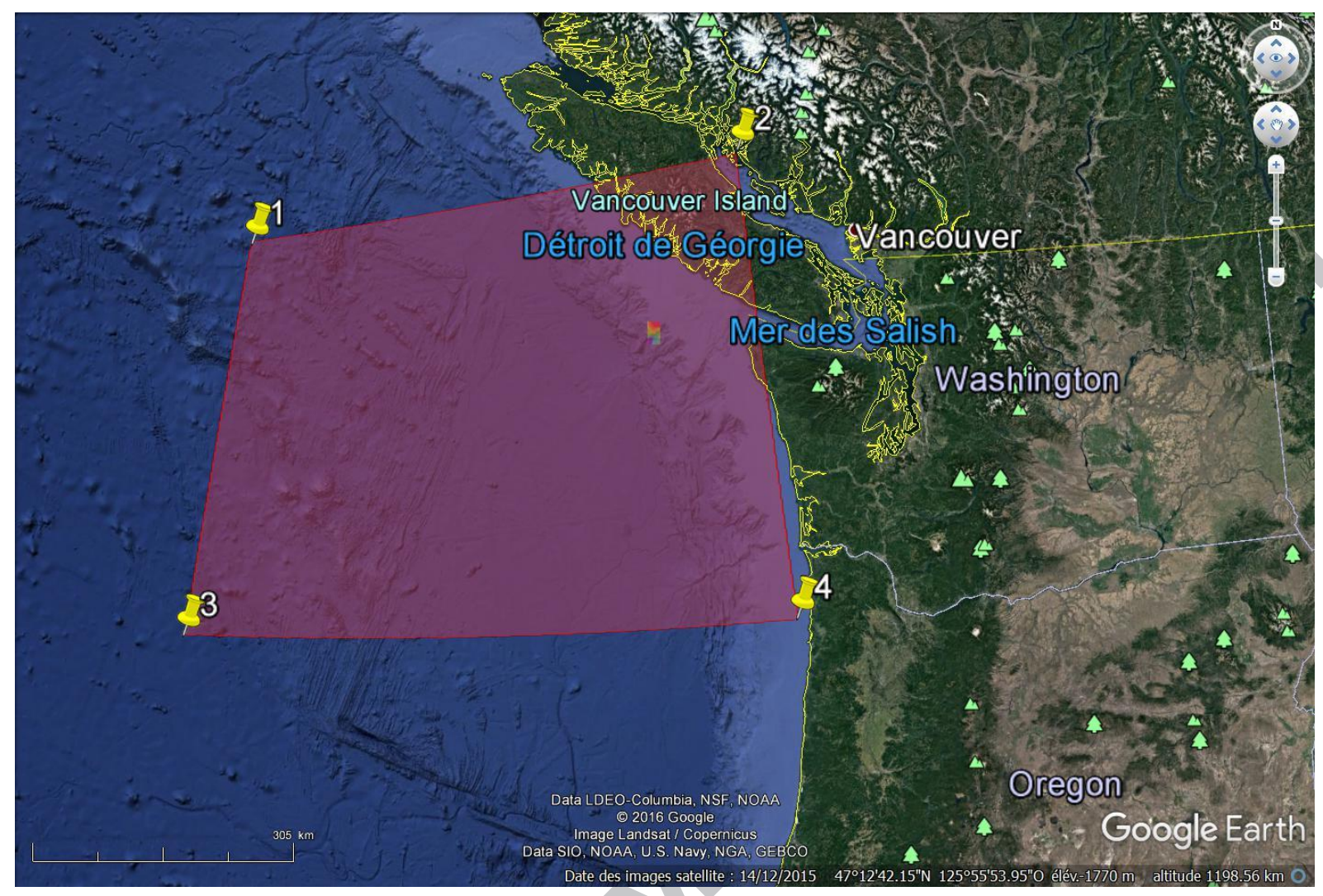

Appendix 5 Map of the surface used to obtain one single value of chlorophyll concentration for the analysis. Chlorophyll (chl) data are a spatial averaged of the square surface around Barkley Canyon (red square surface $=144 \mathrm{~km}^{2}$ ). Coordinates of point $1=49^{\circ} 5^{\prime} 21.50^{\prime \prime} \mathrm{N} ; 132^{\circ} 4^{\prime} 5.62^{\prime \prime} \mathrm{O}$, point $2=50^{\circ} 3^{\prime} 9.32^{\prime \prime} \mathrm{N}$; $124^{\circ} 52^{\prime} 6.47^{\prime \prime} \mathrm{O}$, point $3=45^{\circ} 13^{\prime} 34.96^{\prime \prime} \mathrm{N} ; 132^{\circ} 36^{\prime} 51.32^{\prime \prime} \mathrm{O}$, point $4=45^{\circ} 34^{\prime} 6.82^{\prime \prime} \mathrm{N} ; 124^{\circ} 7^{\prime} 52.19^{\prime \prime} \mathrm{O}$. The chlorophyll concentration is obtained from the 8-day averages given by the MODIS model which uses NASA satellites (neo.sci.gsfc.nasa.gov). 
MRT on megafauna density data Explanatory variable $=$ days

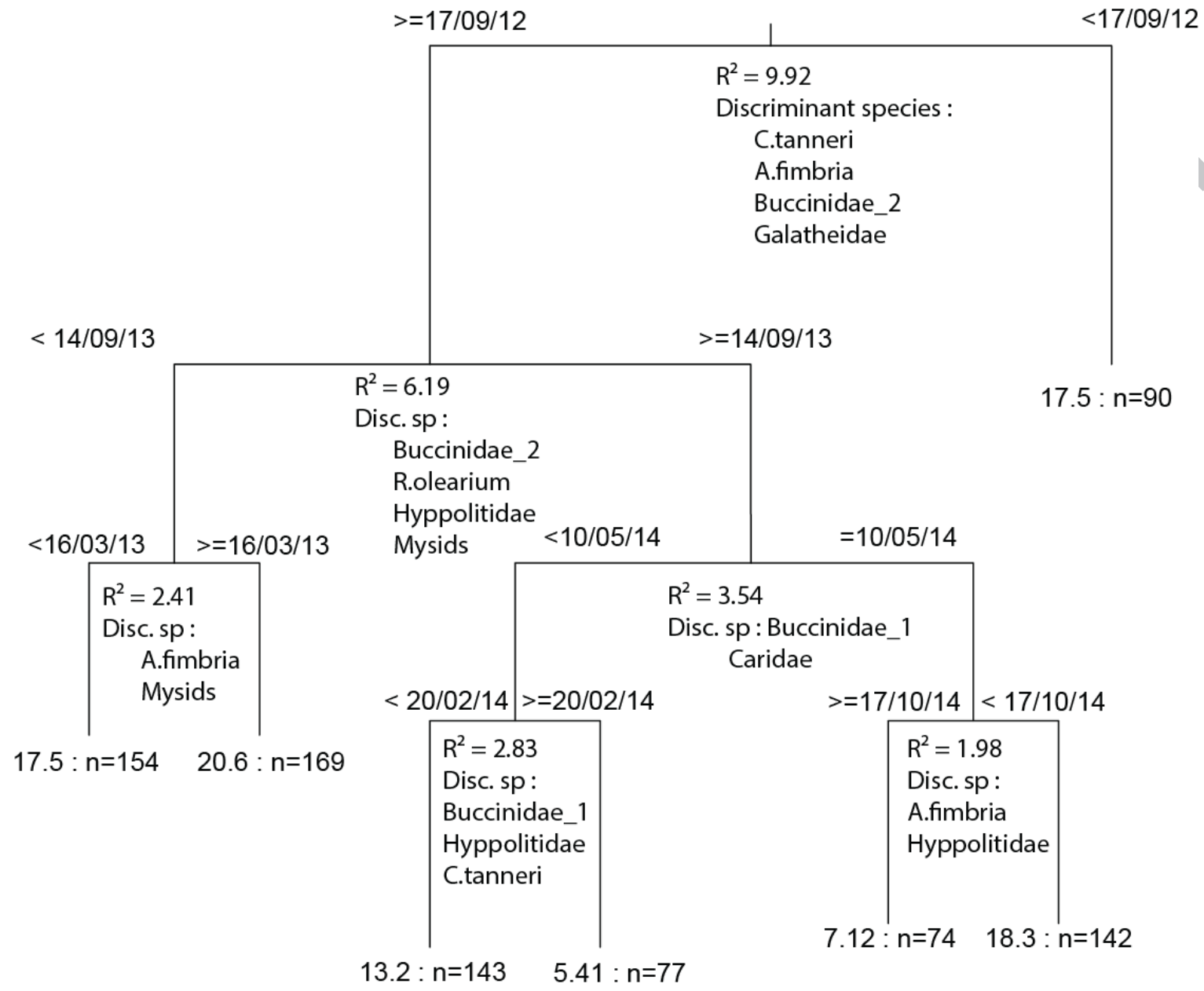

Error : 0.731 CV Error : 0.755 SE : 0.0198

Appendix 6 Results of the MRT analysis performed on megabenthic community sampled from 17 June 2012 to 6 January 2015 in at $985 \mathrm{~m}$ depth from $08 \mathrm{~h} 00$ to $08 \mathrm{~h} 05$ with a stationary video camera at the axis of Barkley Canyon (British Columbia, Canada). For each node the $\mathrm{R}^{2}$ (contribution of each node to the explained variance) and discriminant species are shown. 


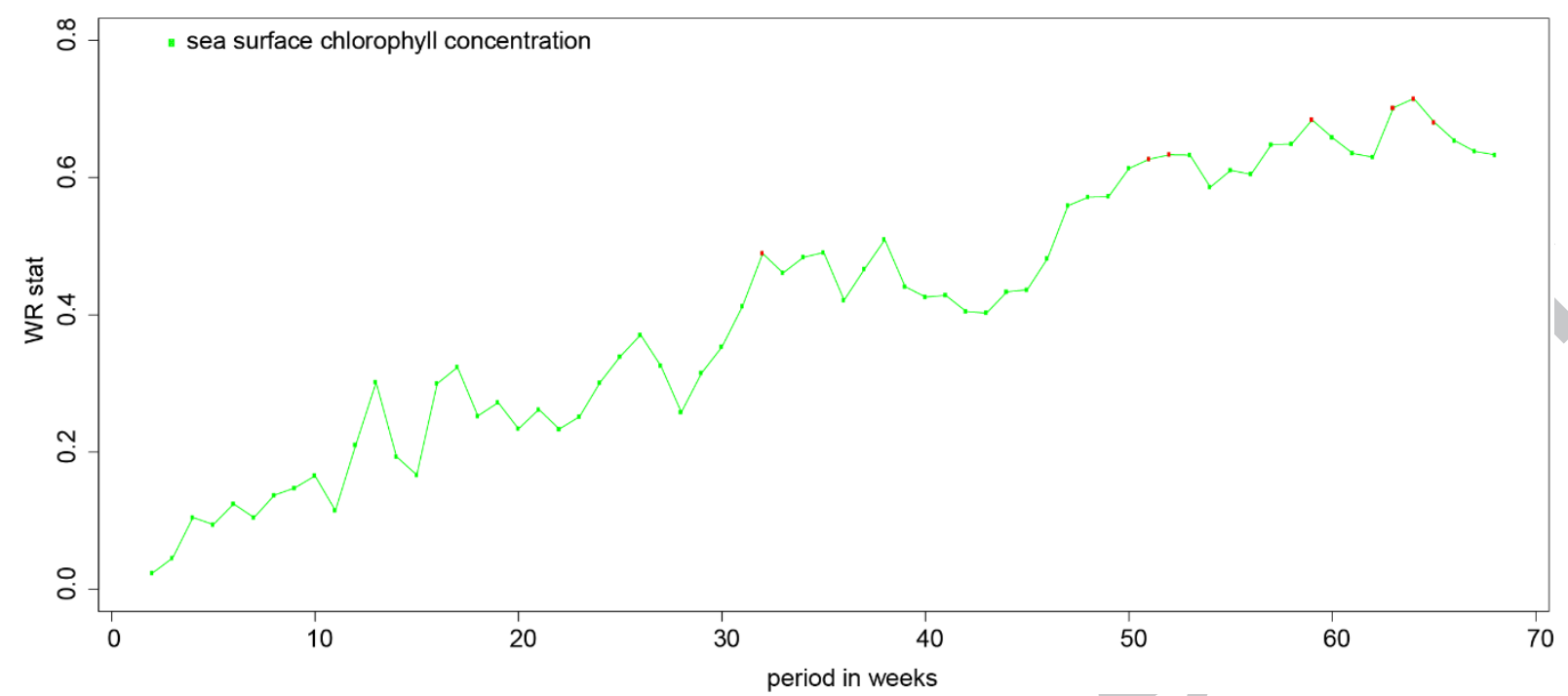

Appendix 4, Figure 1: Whittaker-Robinson periodogram statistics computed for sea surface concentration in chlorophyll, featuring periods comprised between 2 and 68 weeks. Red squares indicate periods that are significant at the $5 \%$ level. Chlorophyll (chl) data values are a spatial averaged of a square surface around Barkley Canyon (British Columbia, Canada; $45^{\circ} 56^{\prime}$ to $50^{\circ} 05^{\prime} \mathrm{N}$, $124^{\circ} 87^{\prime}$ to $132^{\circ} 07^{\prime} \mathrm{W}$ ) obtained from the 8 -day averages given by the MODIS model (neo.sci.gsfc.nasa.gov). 


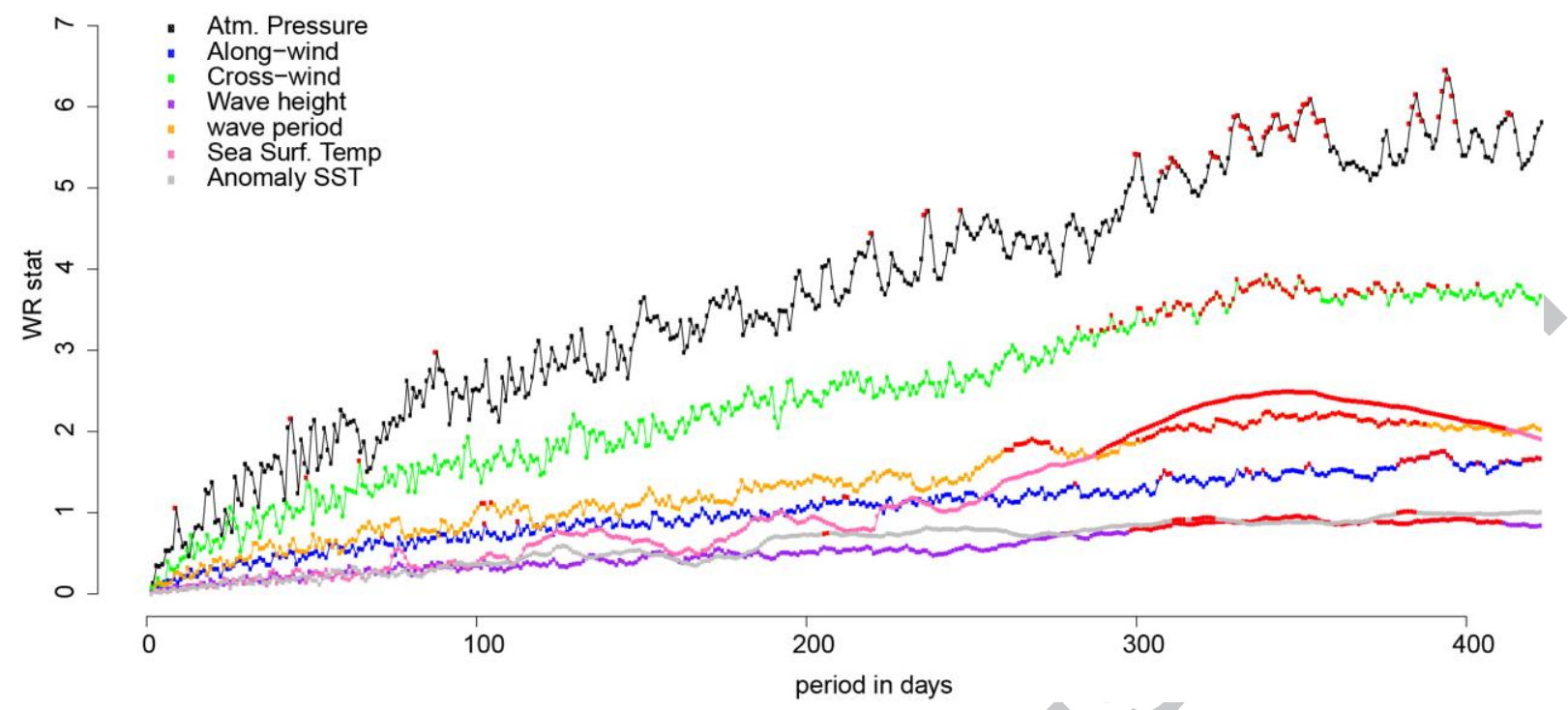

Appendix 4, Figure 2: Whittaker-Robinson periodogram statistics computed for sea surface and weather parameters, featuring periods comprised between 2 and 423 days. Red squares indicate periods that are significant at the $5 \%$ level. Wave height, wind speed, atmospheric pressure, sea surface temperature, anomaly of sea surface temperature (Anomaly SST) parameters are given or derived from hourly data recorded by LaPerouse buoy (Tofino, British Columbia, Canada). 


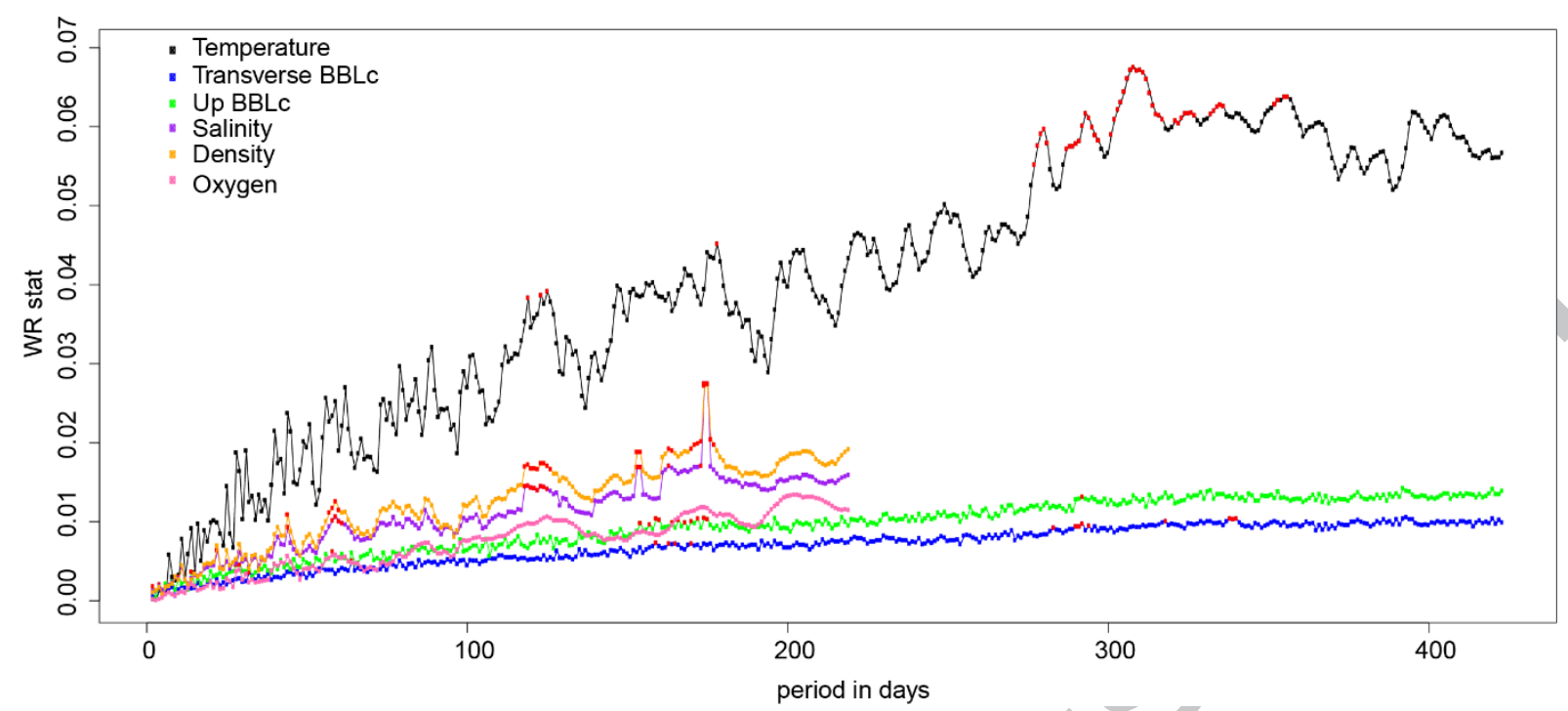

Appendix 4, Figure 3: Robinson periodogram statistics computed for in situ bottom parameter, featuring periods comprised between 2 and 423 days for Temperature and Benthic Boundary Layer currents (BBLC) and between 2 and 219 days for Salinity, Density and Oxygen. Red squares indicate periods that are significant at the $5 \%$ level. In situ BBLC, transverse component and up-canyon component and temperature (from June 2012 to January 2015), and oxygen, salinity and density (from September 2013 to January 2015) were measured at POD1 Ocean Networks Canada observatory site (British Columbia, Canada) using an ADCP for BBLc and temperature, and an oxygen optode and a CTD for the salinity and density 


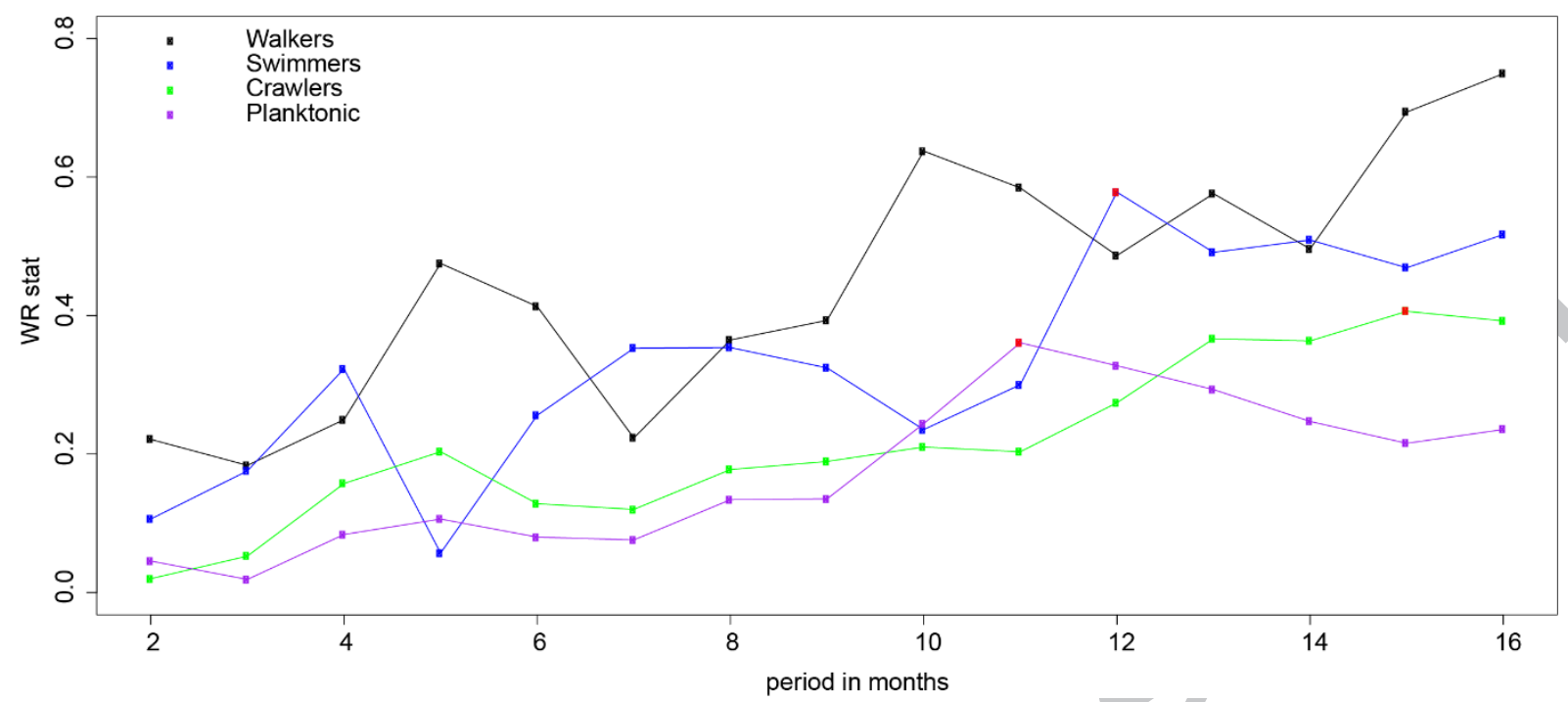

Appendix 4, Figure 4: Whittaker-Robinson periodogram statistics computed for motility categories featuring periods comprised between 2 and 16 months. Species density were aggregated by their motility type and by month, sampled once per day with stationary video camera from $08 \mathrm{~h} 00$ to $08 \mathrm{~h}$ 05 at 985 m depth at the axis of Barkley Canyon (British Columbia, Canada) from 17 June 2012 to 6 January 2015. Red squares indicate periods that are significant at the $5 \%$ level. 


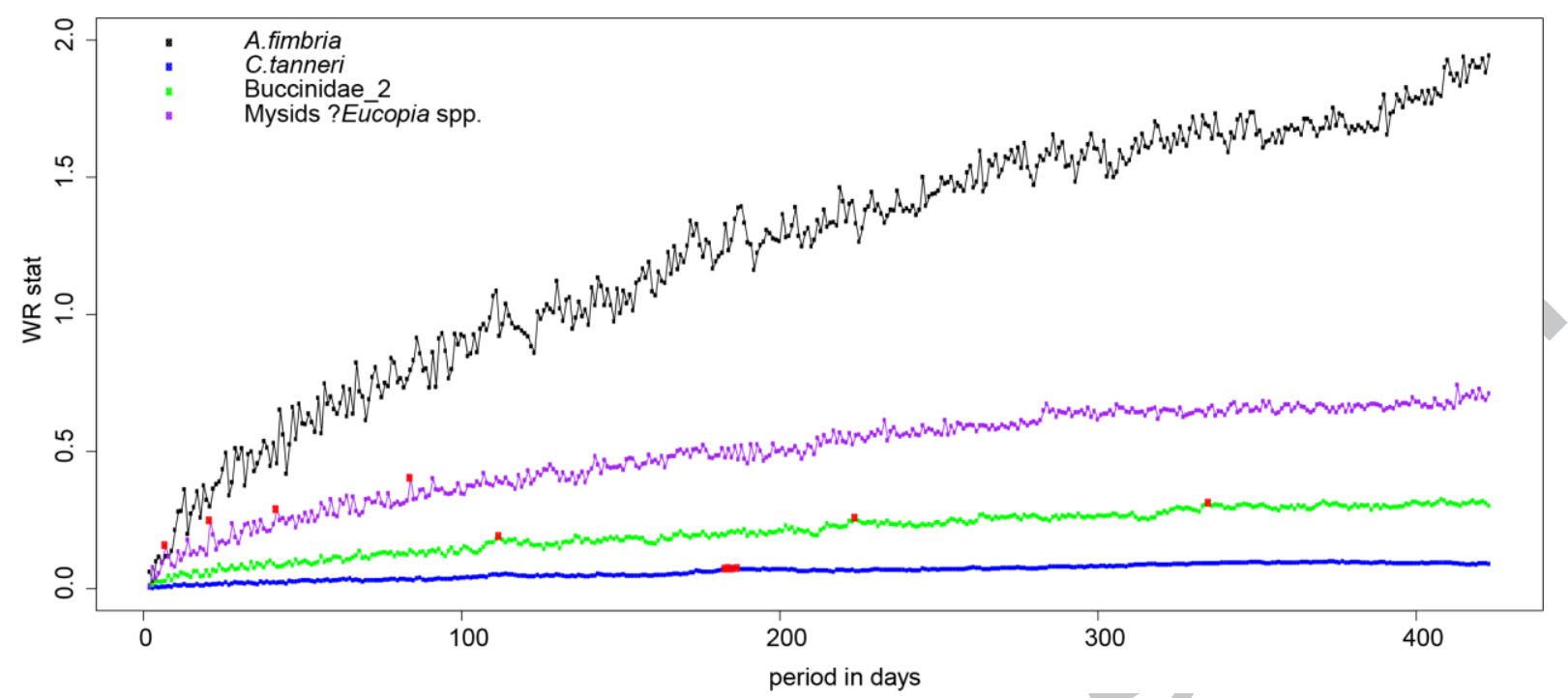

Appendix 4, Figure 5: Whittaker-Robinson periodogram statistics computed for major species densities, featuring periods comprised between 2 and 423 days. Red squares indicate periods that are significant at the $5 \%$ level. Densities were obtained from fauna sampled once per day with stationary video camera from $08 \mathrm{~h} 00$ to $08 \mathrm{~h} 05$ at $985 \mathrm{~m}$ depth at the axis of Barkley Canyon (British Columbia, Canada) from 17 June 2012 to 11 January 2015. 
Table 1: List of instruments measuring hydrographic parameters at POD1 station $\left(48^{\circ} 19^{\prime} \mathrm{N}, 126^{\circ} 03^{\prime} \mathrm{W}, 985 \mathrm{~m}\right.$ depth) from 17 June 2012 to 6 January 2015 at the axis of Barkley Canyon (British Columbia, Canada) and collecting atmospheric information at La Perouse buoy $\left(48^{\circ} 50^{\prime} \mathrm{N}, 126^{\circ} 00^{\prime} \mathrm{W}\right.$, Tofino, British Columbia, Canada). We also used 8-day averaged data provided by the MODIS model which uses NASA satellites to obtain surface chlorophyll in a square surface around Barkley Canyon $\left(45^{\circ} 56^{\prime}\right.$ to $50^{\circ} 05^{\prime} \mathrm{N}, 124^{\circ} 87^{\prime}$ to $\left.132^{\circ} O 7^{\prime} W\right)$. BBLC = Benthic Boundary Layer current

\begin{tabular}{|c|c|c|c|c|}
\hline $\begin{array}{l}\text { Sampling } \\
\text { Site }\end{array}$ & $\begin{array}{c}\text { Instruments } \\
\text { Sampling dates }\end{array}$ & Measured parameters & $\begin{array}{l}\text { Sampling } \\
\text { frequency }\end{array}$ & Units \\
\hline \multirow{3}{*}{$\begin{array}{l}\text { Sea-floor } \\
\text { Data }\end{array}$} & $\begin{array}{c}\text { ADCP } \\
\text { June- } 12 \text { to Jan-15 }\end{array}$ & $\begin{array}{l}\text { Northward BBLc (Ubar) } \\
\text { Eastward BBLc (Vbar) } \\
\text { Temperature }\end{array}$ & $\begin{array}{l}10 \mathrm{sec} \\
10 \mathrm{sec} \\
10 \mathrm{sec}\end{array}$ & $\begin{array}{l}\mathrm{m} / \mathrm{s} \\
\mathrm{m} / \mathrm{s} \\
{ }^{\circ} \mathrm{C}\end{array}$ \\
\hline & $\begin{array}{c}\text { CTD } \\
\text { Sept-13 to Jan-15 }\end{array}$ & $\begin{array}{c}\text { Pressure } \\
\text { Salinity } \\
\text { Conductivity } \\
\text { Density } \\
\text { Temperature } \\
\end{array}$ & $\begin{array}{l}1 \mathrm{~min} \\
1 \mathrm{~min} \\
1 \mathrm{~min} \\
1 \mathrm{~min} \\
1 \mathrm{~min}\end{array}$ & $\begin{array}{c}\mathrm{dbar} \\
\mathrm{psu} \\
\mathrm{S} / \mathrm{m} \\
\mathrm{kg} / \mathrm{m} 3 \\
{ }^{\circ} \mathrm{C} \\
\end{array}$ \\
\hline & $\begin{array}{c}\text { Oxygen optod } \\
\text { Sept-13 to Jan-15 }\end{array}$ & Oxygen & $1 \mathrm{~min}$ & $\mathrm{~mL} / \mathrm{L}$ \\
\hline $\begin{array}{c}\text { Weather } \\
\text { data }\end{array}$ & $\begin{array}{l}\text { La Perouse } B a \\
\text { June- } 12 \text { to }\end{array}$ & $\begin{array}{l}\text { Significant wave height } \\
\text { Max. zero crossing wave height } \\
\text { Wave spectrum peak period } \\
\text { Direction from which the wind is } \\
\text { blowing } \\
\text { Horizontal wind speed } \\
\text { Atmospheric pressure }\end{array}$ & $\begin{array}{l}1 \text { hour } \\
1 \text { hour } \\
1 \text { hour } \\
1 \text { hour } \\
1 \text { hour } \\
1 \text { hour }\end{array}$ & $\begin{array}{c}\mathrm{m} \\
\mathrm{m} \\
\mathrm{s} \\
{ }^{\circ} \text { TRUE } \\
\mathrm{m} / \mathrm{s} \\
\mathrm{mbar}\end{array}$ \\
\hline $\begin{array}{c}\text { Sea-surface } \\
\text { Data }\end{array}$ & $\begin{array}{c}\text { NASA Satellites } \\
\text { June-12 to Jan-15 }\end{array}$ & Surface chlorophyll concentration & 8 days & $\mathrm{mg} / \mathrm{m} 3$ \\
\hline
\end{tabular}


Table 2: Characteristics of cameras installed at each maintenance cruise (1st- June 2012, 2nd-May 2013 and 3rd-May 2014) at POD1 station at $985 \mathrm{~m}$ depth at the axis of Barkley Canyon (British Columbia, Canada). Dates indicate periods in between changes of the camera field of view (for maintenance or technical issues).

\begin{tabular}{cccccc}
\hline Cruises & Dates & Camera & Coordinates & $\begin{array}{c}\text { Sweep } \\
\text { angle }\end{array}$ & $\begin{array}{c}\text { Surface } \\
\text { covered }\end{array}$ \\
\hline \multirow{2}{*}{2012} & 17 June 12 to 11 May 13 & $\begin{array}{c}\text { AXIS P1347 } \\
\text { SubAqua } \\
\text { Im.Syst.Inc. }\end{array}$ & $\begin{array}{c}48.31676 \\
-126.05020\end{array}$ & $360^{\circ}$ & $6.1 \mathrm{~m}^{2}$ \\
\hline \multirow{2}{*}{2013} & 12 May 13 to 15 Feb 14 & Dragonfish & 48.31658 & $360^{\circ}$ & $9 \mathrm{~m}^{2}$ \\
& 16 Feb 14 to 05 May 14 & SubC Imaging & -126.0502 & $360^{\circ}$ & $7.2 \mathrm{~m}^{2}$ \\
\hline \multirow{2}{*}{2014} & 11 May 14 to 11 Aug 14 & Dragonfish & 48.316644 & $180^{\circ} * 2$ & $6.1 \mathrm{~m}^{2}$ \\
& 12 Aug 14 to 6 Jan 15 & SubC Imaging & -126.050166 & $100^{\circ}+45^{\circ}$ & $3.9 \mathrm{~m}^{2}$ \\
\hline
\end{tabular}


Table 3: Environmental parameters from 17 June 2012 to 6 January 2015 measured (i) at $985 \mathrm{~m}$ depth at the axis of Barkley canyon and (ii) at the sea surface around Barkley Canyon (British Columbia, Canada). Wave height (WH), wind speed (WS), atmospheric pressure (AtmP), sea surface temperature (SST), daily anomaly of sea surface temperature (ASST) parameters are given or derived from hourly data recorded by LaPerouse buoy (Tofino, British Columbia). Chlorophyll (chl) data values are a spatial averaged of a square surface around Barkley Canyon $\left(45^{\circ} 56^{\prime}\right.$ to $50^{\circ} 05^{\prime} \mathrm{N}, 124^{\circ} 87^{\prime}$ to $\left.132^{\circ} 07^{\prime} \mathrm{W}\right)$ obtained from the 8 -day averages given by the MODIS model (neo.sci.gsfc.nasa.gov). In situ absolute value of BBLc, transverse component (Ubar) and upcanyon component (Vbar) and temperature (Temp) (from June 2012 to January 2015), and oxygen ([O2]), salinity (Sal) and density (De) (from September 2013 to January 2015) were measured at POD1 ONC observatory site using ADCP for BBLC and temperature, an Oxygen optode and a CTD for the salinity and density.

\begin{tabular}{|c|c|c|c|c|c|c|c|c|c|c|c|c|}
\hline & \multicolumn{6}{|c|}{ Surface data } & \multicolumn{6}{|c|}{ In-situ benthic boundary layer data } \\
\hline & $\begin{array}{c}\mathbf{W H} \\
\mathrm{m}\end{array}$ & $\begin{array}{l}\text { WS } \\
\mathrm{m} / \mathrm{s}\end{array}$ & $\begin{array}{l}\text { AtmP } \\
\text { mbar }\end{array}$ & $\begin{array}{l}\text { SST } \\
{ }^{\circ} \mathrm{C}\end{array}$ & $\begin{array}{c}\text { ASST } \\
{ }^{\circ} \mathrm{C}\end{array}$ & $\begin{array}{c}\mathrm{Chl} \\
\mathrm{mg} / \mathrm{L}\end{array}$ & $\begin{array}{c}{[0]} \\
\mathrm{mL} / \mathrm{L}\end{array}$ & $\begin{array}{l}\text { Sal } \\
\text { psu }\end{array}$ & $\begin{array}{c}\text { De } \\
\mathrm{kg} / \mathrm{m} 3\end{array}$ & $\begin{array}{c}\text { Temp } \\
{ }^{\circ} \mathrm{C}\end{array}$ & $\begin{array}{c}|\mathrm{Vbar}| \\
\mathrm{m} / \mathrm{s}\end{array}$ & $\begin{array}{c}\text { |Ubar| } \\
\mathrm{m} / \mathrm{s}\end{array}$ \\
\hline Min & 0.4 & 0 & 976.7 & 7.2 & -4 & 0.29 & 0.24 & 34.00 & 1031 & 3.51 & 0 & 0 \\
\hline Max & 8.2 & 19.1 & 1045.3 & 16.7 & 3.8 & 7.09 & 0.34 & 34.40 & 1032 & 4.07 & 0.2 & 0.13 \\
\hline Mean & 2.0 & 5.6 & 1017.6 & 11.7 & -0.2 & 1.17 & 0.29 & 34.38 & 1032 & 3.76 & 0.03 & 0.02 \\
\hline Sd & 1.22 & 3.57 & 8.10 & 2.47 & 1.60 & 0.871 & 0.020 & 0.023 & 0.026 & 0.090 & 0.020 & 0.015 \\
\hline
\end{tabular}


Table 4: List of benthic megafauna recorded from the axis of Barkley Canyon (British Columbia, Canada) at 985 m depth from 17 June 2012 to 6 January 2015 and identified to the lowest taxonomic rank possible. Species considered as major are highlighted in blue and those considered as rare in grey. Buccinidae_OTU_2 could also be a member of the Ranellidae family. Actiniarians were always observed on Buccinidae_OTU_2 shell and are thus categorized as crawlers.

\begin{tabular}{|c|c|c|c|}
\hline Phylum & OTUs name & Total of observations & Motility \\
\hline \multirow[t]{11}{*}{ Chordata } & Anoplopoma fimbria & 10740 & Swimmer \\
\hline & Sebastolobus sp. & 11 & Swimmer \\
\hline & Coryphaenoides sp. & 125 & Swimmer \\
\hline & Bothrocara molle & 24 & Swimmer \\
\hline & Eelpout_OTU_1 & 781 & Planktonic \\
\hline & Lycodapus sp. & 2 & Swimmer \\
\hline & Lycenchelis sp. & 27 & Swimmer \\
\hline & Eptatretus sp. & 99 & Swimmer \\
\hline & Careproctus melanurus & 1 & Swimmer \\
\hline & Bathyagonus niggripis & 32 & Swimmer \\
\hline & Embassichthys bathybius & 2 & Swimmer \\
\hline \multirow[t]{2}{*}{ Mollusca } & Buccinidae_OTU_1 & 1124 & Crawler \\
\hline & $\begin{array}{l}\text { Buccinidae_OTU_2 } \\
\text { Ranellidae_OTU_1 }\end{array}$ & 3217 & Crawler \\
\hline \multirow[t]{7}{*}{ Arthropoda } & Paguroidea & 98 & Walker \\
\hline & Chionoecetes tanneri & 49298 & Walker \\
\hline & Galatheidae & 283 & Walker \\
\hline & Hippolytidae & 1070 & Walker \\
\hline & Caridae & 782 & Walker \\
\hline & Mysids: ?Eucopia spp. & 4172 & Planktonic \\
\hline & Pandalidae & 2 & Walker \\
\hline \multirow[t]{3}{*}{ Echinodermata } & Asteroidea_OTU_1 & 38 & Crawler \\
\hline & Solasteridae & 2 & Crawler \\
\hline & Ophiuroidea & 2 & Crawler \\
\hline \multirow[t]{3}{*}{ Cnidaria } & Actiniaria & 82 & Crawler* \\
\hline & Scyphozoa & 197 & Planktonic \\
\hline & Poralia rufescens & 130 & Planktonic \\
\hline Ctenophora & Ctenophora & 23 & Planktonic \\
\hline Annelida & Polychaete & 3 & Crawler/Swimmer \\
\hline
\end{tabular}


Table 5: Results of the correlations performed on the densities of all OTUs aggregated by month and motility at $985 \mathrm{~m}$ depth at the axis of Barkley Canyon (British Columbia, Canada) from 17 June 2012 to 11 January 2015. $T$ = Kendall rank correlation coefficient and « ns » = non-significant.

\begin{tabular}{ccccccc} 
& \multicolumn{2}{c}{ Swimmers } & \multicolumn{2}{c}{ Planktonic } & \multicolumn{2}{c}{ Crawlers } \\
\hline & $\mathrm{T}$ & $\mathrm{p}$-value & $\mathrm{T}$ & $\mathrm{p}$-value & $\mathrm{T}$ & $\mathrm{p}$-value \\
Walkers & 0.21 & 0.089 & 0.46 & 0.000 & 0.24 & 0.050 \\
Swimmers & & & 0.31 & 0.012 & & $\mathrm{~ns}$ \\
Planktonic & & & & & & $\mathrm{ns}$ \\
\hline
\end{tabular}


Table 6: $\mathrm{R}^{2}$ and probabilities related to the temporal analysis of the epibenthic megafaunal community sampled with a stationary video camera from $08 \mathrm{~h} 00$ to $08 \mathrm{~h} 05$ every day at $985 \mathrm{~m}$ depth at the axis of Barkley Canyon (British Columbia, Canada). First line: $\mathrm{R}^{2}$ of each spatial sub-model. Second line: $\mathrm{R}^{2}$ of the regression of the submodel (fitted values) on a subset of backward-selected environmental variables. Third line: product of the two previous lines, i.e. variation of the community data explained by the environmental variables at the scale considered. Other lines: p-values of the regression coefficients of the environmental variables in the model considered. (*** for $\mathrm{p}$-value<0.0001; ** for $\mathrm{p}$-value $<0.05$, / for non-tested as $\mathrm{R}^{2}$ was $=0$ ).

\begin{tabular}{|c|c|c|c|c|}
\hline & $\begin{array}{c}\text { Axis } \\
\text { community }\end{array}$ & Broad & Medium & Fine \\
\hline Significant period (days) & & $\begin{array}{l}212-243 \\
342-346\end{array}$ & $46-51$ & 8 \\
\hline $\mathrm{R}^{2}$ adj of dbMEM submodel on axis community & & 0.269 & 0.0373 & 0.044 \\
\hline$R^{2}$ adj of environment on submodel & & 0.080 & 0.008 & 0.0004 \\
\hline$R^{2}$ adj of environment on axis community & 0.004 & 0.022 & 0.0003 & 0.00001 \\
\hline Wave height & $* * *$ & $* * *$ & $* * *$ & / \\
\hline Wave period & *** & $* * *$ & & / \\
\hline Anomaly of sea surface temperature & $* * *$ & $* * *$ & $* * *$ & / \\
\hline Sea surface temperature & $* * *$ & $* * *$ & & / \\
\hline Atmospheric pressure & $* * *$ & $* * *$ & & / \\
\hline Along-slope wind & $* * *$ & $* *$ & & / \\
\hline Cross-slope wind & $* *$ & $* *$ & & / \\
\hline Up-canyon boundary layer current & $* *$ & $* *$ & & / \\
\hline Cross-canyon boundary layer current & $* *$ & $* *$ & & / \\
\hline Temperature & $* * *$ & $* *$ & $* * *$ & l \\
\hline
\end{tabular}


Table 7: Results of the correlations performed between daily anomaly of sea surface temperature -calculated using sea surface temperature $\left({ }^{\circ} \mathrm{C}\right.$ ) measured from 1988 to 2015 at LaPerouse buoy (Tofino, British Columbia, Canada) - and the daily densities of major OTUs observed at $985 \mathrm{~m}$ depth in the axis of Barkley Canyon (British Columbia, Canada) from 17 June 2012 to 11 January 2015. $T$ = Kendall rank correlation coefficient and « ns » = non-significant.

\begin{tabular}{ccc} 
& \multicolumn{2}{c}{ ASST } \\
\cline { 2 - 3 } A. fimbria & T & p-value \\
\cline { 2 - 3 } C. tanneri & 0.06 & 0.014 \\
Mysids ?Eucopia spp. & 0.14 & $1.40 \mathrm{e}-09$ \\
Buccinidae_OTU_2 & 0.17 & $1.60 \mathrm{e}-12$ \\
\hline
\end{tabular}

